University of Nebraska - Lincoln

DigitalCommons@University of Nebraska - Lincoln

July 2001

\title{
Historical Water-Quality Data for the High Plains Regional Ground- Water Study Area in Colorado, Kansas, Nebraska, New Mexico, Oklahoma, South Dakota, Texas, and Wyoming, 1930-98
}

David W. Litke

U.S. GEOLOGICAL SURVEY

Follow this and additional works at: https://digitalcommons.unl.edu/usgspubs

Part of the Earth Sciences Commons

Litke, David W., "Historical Water-Quality Data for the High Plains Regional Ground-Water Study Area in Colorado, Kansas, Nebraska, New Mexico, Oklahoma, South Dakota, Texas, and Wyoming, 1930-98" (2001). Publications of the US Geological Survey. 1.

https://digitalcommons.unl.edu/usgspubs/1

This Article is brought to you for free and open access by the US Geological Survey at DigitalCommons@University of Nebraska - Lincoln. It has been accepted for inclusion in Publications of the US Geological Survey by an authorized administrator of DigitalCommons@University of Nebraska - Lincoln. 


\section{Historical Water-Quality Data for the}

High Plains Regional Ground-Water Study Area in Colorado, Kansas, Nebraska, New Mexico, Oklahoma, South Dakota, Texas, and Wyoming, 1930-98

By David W. Litke

U.S. GEOLOGICAL SURVEY

Water-Resources Investigations Report 00-4254

NATIONAL WATER-QUALITY ASSESSMENT PROGRAM 


\title{
U.S. DEPARTMENT OF THE INTERIOR GALE A. NORTON, Secretary
}

\author{
U.S. GEOLOGICAL SURVEY \\ Charles G. Groat, Director
}

The use of firm, trade, and brand names in this report is for identification purposes only and does not constitute endorsement by the U.S. Geological Survey.

For additional information write to:

District Chief

U.S. Geological Survey

Box 25046, Mail Stop 415

Denver Federal Center

Denver, CO 80225-0046
Copies of this report can be purchased from:
U.S. Geological Survey
Information Services
Box 25286
Denver Federal Center
Denver, CO 80225 


\section{FOREWORD}

The U.S. Geological Survey (USGS) is committed to serve the Nation with accurate and timely scientific information that helps enhance and protect the overall quality of life, and facilitates effective management of water, biological, energy, and mineral resources. (http://www.usgs.gov/). Information on the quality of the Nation's water resources is of critical interest to the USGS because it is so integrally linked to the long-term availability of water that is clean and safe for drinking and recreation and that is suitable for industry, irrigation, and habitat for fish and wildlife. Escalating population growth and increasing demands for the multiple water uses make water availability, now measured in terms of quantity and quality, even more critical to the long-term sustainability of our communities and ecosystems.

The USGS implemented the National Water-Quality Assessment (NAWQA) Program to support national, regional, and local information needs and decisions related to water-quality management and policy. (http://water.usgs.gov/nawqa). Shaped by and coordinated with ongoing efforts of other Federal, State, and local agencies, the NAWQA Program is designed to answer: What is the condition of our Nation's streams and ground water? How are the conditions changing over time? How do natural features and human activities affect the quality of streams and ground water, and where are those effects most pronounced? By combining information on water chemistry, physical characteristics, stream habitat, and aquatic life, the NAWQA Program aims to provide sciencebased insights for current and emerging water issues and priorities. NAWQA results can contribute to informed decisions that result in practical and effective water-resource management and strategies that protect and restore water quality.

Since 1991, the NAWQA Program has implemented interdisciplinary assessments in more than 50 of the Nation's most important river basins and aquifers, referred to as Study Units.

(http://water.usgs.gov/nawqa/nawqamap.html). Collectively, these Study Units account for more than 60 percent of the overall water use and population served by public water supply, and are representative of the Nation's major hydrologic landscapes, priority ecological resources, and agricultural, urban, and natural sources of contamination.

Each assessment is guided by a nationally consistent study design and methods of sampling and analysis.

The assessments thereby build local knowledge about water-quality issues and trends in a particular stream or aquifer while providing an understanding of how and why water quality varies regionally and nationally. The consistent, multi-scale approach helps to determine if certain types of water-quality issues are isolated or pervasive, and allows direct comparisons of how human activities and natural processes affect water quality and ecological health in the Nation's diverse geographic and environmental settings. Comprehensive assessments on pesticides, nutrients, volatile organic compounds, trace metals, and aquatic ecology are developed at the national scale through comparative analysis of the Study-Unit findings. (http://water.usgs.gov/nawqa/natsyn.html).

The USGS places high value on the communication and dissemination of credible, timely, and relevant science so that the most recent and available knowledge about water resources can be applied in management and policy decisions. We hope this NAWQA publication will provide you the needed insights and information to meet your needs, and thereby foster increased awareness and involvement in the protection and restoration of our Nation's waters.

The NAWQA Program recognizes that a national assessment by a single program cannot address all waterresource issues of interest. External coordination at all levels is critical for a fully integrated understanding of watersheds and for cost-effective management, regulation, and conservation of our Nation's water resources. The Program, therefore, depends extensively on the advice, cooperation, and information from other Federal, State, interstate, Tribal, and local agencies, non-government organizations, industry, academia, and other stakeholder groups. The assistance and suggestions of all are greatly appreciated.

Robert M. Hirsch

Associate Director for Water 


\section{CONTENTS}

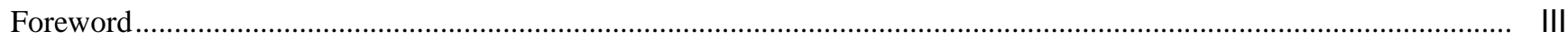

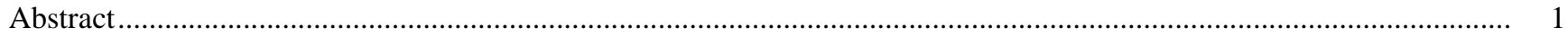

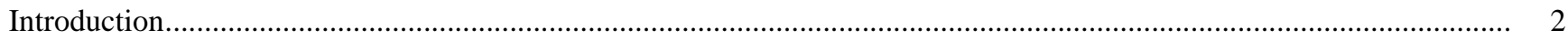

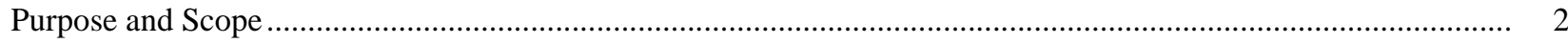

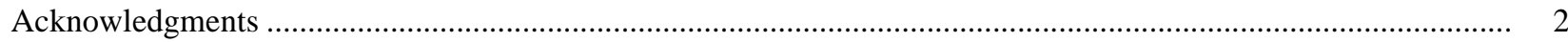

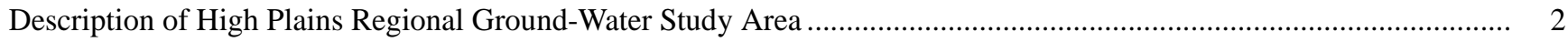

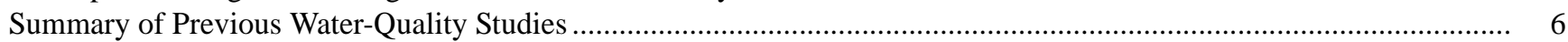

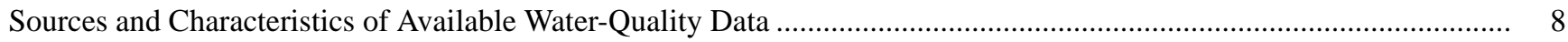

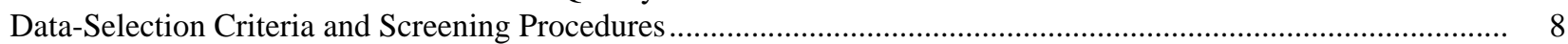

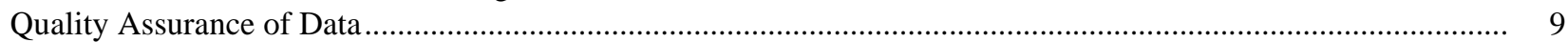

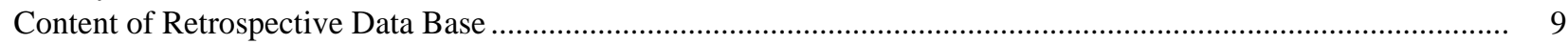

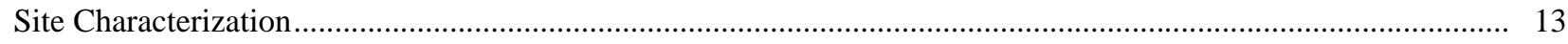

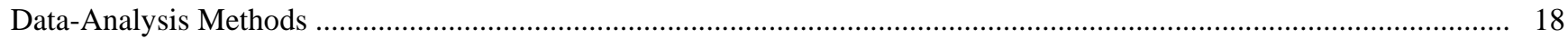

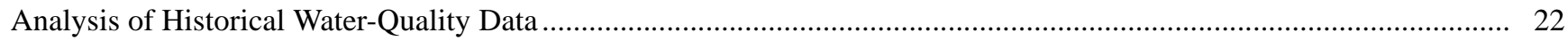

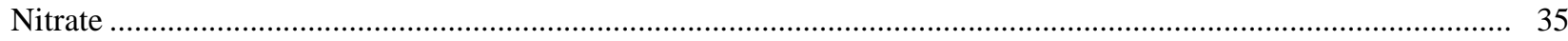

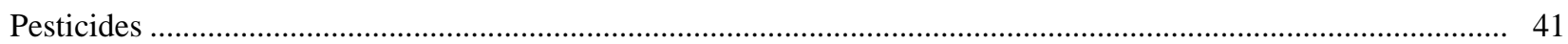

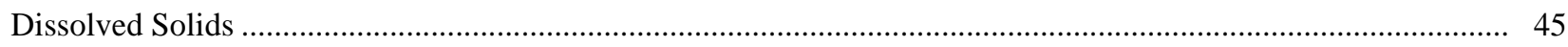

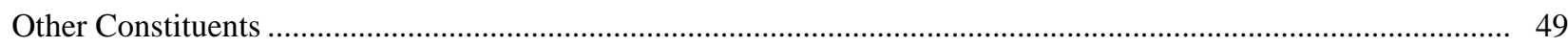

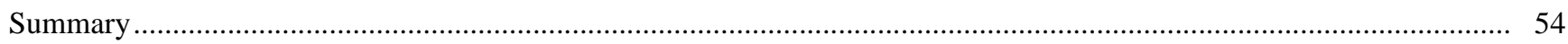

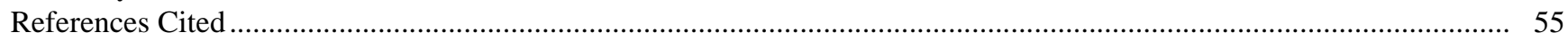

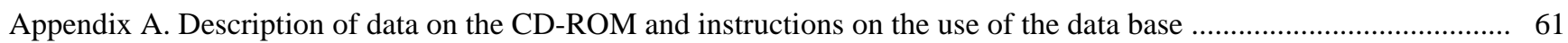

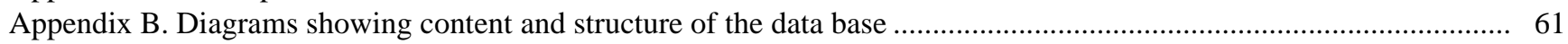

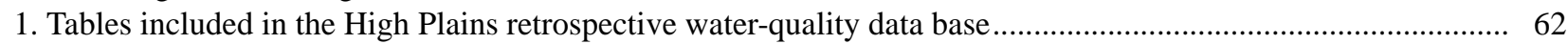

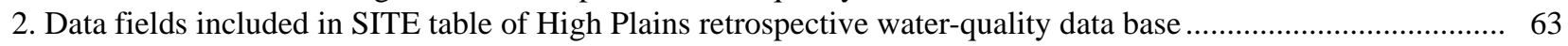

3. Data fields included in QW_RESULT table of High Plains retrospective water-quality data base ...................... 64

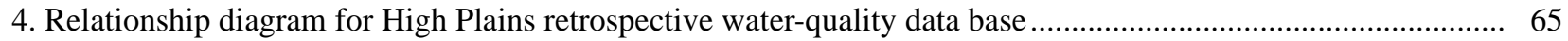

Appendix C. High Plains retrospective data base on CD-ROM (in pocket)

\section{FIGURES}

1-3. Maps showing:

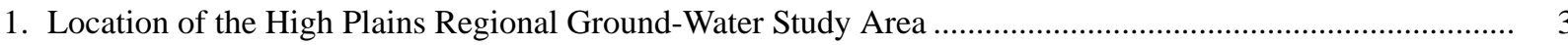

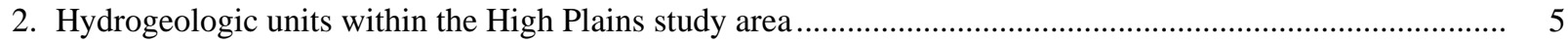

3. Location of sampling sites in the High Plains retrospective data base ................................................. 11

4. Graphs showing temporal distribution of water-quality observations for selected parameter groups, 1950-98.

5. Map showing geographic distribution of observations for nutrients, pesticides, trace elements,

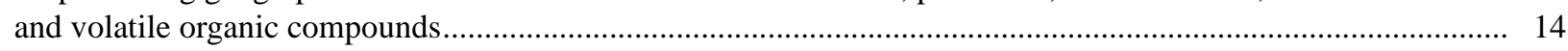

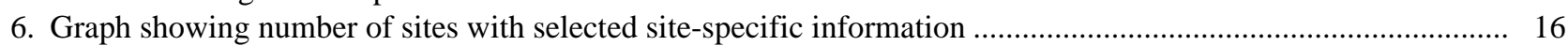

7-10. Maps showing:

7. Depth to water during 1997 in the High Plains study area.................................................................... 17

8. Percentage of land irrigated during 1980 in the High Plains study area ................................................. 19

9. Nitrogen application rates for manure and fertilizer in the High Plains study area, by county, 1992 ............. 20

10. Soil infiltration rates in the High Plains study area............................................................................. 21

11. Boxplot showing distribution of nitrate concentrations, by decade ........................................................... 37

12. Graph showing temporal variability of nitrate concentrations, by hydrogeologic unit ...................................... 37

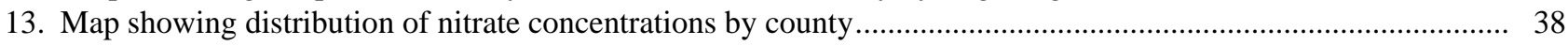

14. Graph showing relation between nitrate concentration and depth of sample below water table, by hydrogeologic unit

15. Map showing locations of sites with pesticide data and pesticide detections for atrazine, metolachlor, simazine, and prometon

16. Boxplot showing distribution of dissolved-solids concentrations, by decade 
17. Graph showing temporal variability of dissolved-solids concentrations, by hydrogeologic unit.

18. Map showing geographic distribution of dissolved-solids concentration data prior to 1980 and data after 1980.

19. Boxplots showing major ion chemistry of High Plains ground water, by hydrogeologic unit.

20. Map showing distribution of the percentage of iron, manganese, and fluoride observations that exceeded drinking-water standards.

21. Map showing distribution of the number of radon and uranium observations that exceeded drinking-water standards

\section{TABLES}

1. Selected characteristics of hydrogeologic units within the High Plains study area ............................................. 6

2. Summary of selected water-quality studies conducted within the High Plains study area ..................................... 7

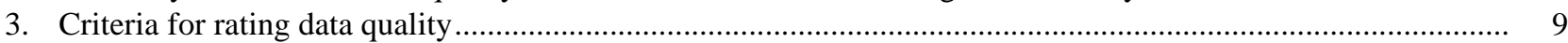

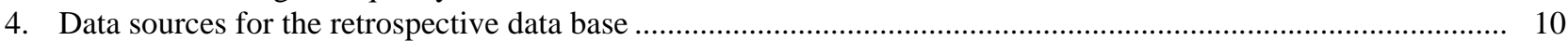

5. Geographic characteristics assigned to sites by using a geographic information system ...................................... 18

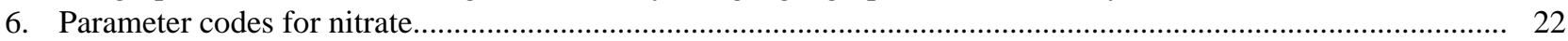

7. Descriptive statistics for selected constituents or properties by hydrogeologic unit, 1980-98 ............................. 23

8. Selected constituents from the retrospective data base compared to drinking-water standards ............................ 34

9. Kendall's tau correlation coefficients between nitrate concentrations and ancillary variables, by hydrogeologic unit

10. Most commonly used and detected pesticides in the High Plains study area ................................................... 42

11. Kendall's tau correlation coefficients between dissolved-solids concentrations and ancillary variables, by hydrogeologic unit

\section{ABBREVIATIONS USED IN THIS REPORT}

$\begin{aligned} \text { GIRAS } & \text { Geographic Information Retrieval and Analysis System } \\ \text { GIS } & \text { Geographic Information System } \\ \text { MCL } & \text { maximum contaminant level } \\ \mu \mathrm{g} / \mathrm{L} & \text { micrograms per liter } \\ \mathrm{mg} / \mathrm{kg} & \text { milligrams per kilogram } \\ \mathrm{mg} / \mathrm{L} & \text { milligrams per liter } \\ \text { Mgal/d } & \text { million gallons per day } \\ \text { NAWQA } & \text { National Water-Quality Assessment Program } \\ \text { MCL } & \text { maximum contaminant level } \\ \text { NURE } & \text { National Uranium Resource Evaluation } \\ \text { pCi/L } & \text { picocuries per liter } \\ \text { PMCL } & \text { proposed maximum contaminant level } \\ \text { RASA } & \text { Regional Aquifer-System Analysis } \\ \text { SS } & \text { secondary standard } \\ \text { STORET } & \text { U.S Environmental Protection Agency Storage and Retrieval System } \\ \text { USGS } & \text { U.S. Geological Survey } \\ \text { USEPA } & \text { U.S. Environmental Protection Agency } \\ \text { WWW } & \text { World Wide Web }\end{aligned}$

Sea level: In this report "sea level" refers to the National Geodetic Vertical Datum of 1929_ a geodetic datum derived from a general adjustment of the first-order level nets of the United States and Canada, formerly called Sea Level Datum of 1929.

Altitude, as used in this report, refers to distance above or below sea level. 


\title{
Historical Water-Quality Data for the High Plains Regional Ground-Water Study Area in Colorado, Kansas, Nebraska, New Mexico, Oklahoma, South Dakota, Texas, and Wyoming, 1930-98
}

\author{
By David W. Litke
}

\section{Abstract}

The High Plains aquifer underlies 174,000 square miles in parts of eight States and includes eight primary hydrogeologic units, including the well-known Ogallala Formation. The High Plains aquifer is an important resource, providing water for 27 percent of the Nation's irrigated agricultural lands in an otherwise dry landscape. Since the 1980's there has been concern over the sustainability of the aquifer due to water-level declines caused by substantial pumping. Water quality of the aquifer is a more recent concern. As part of the U.S. Geological Survey's National Water-Quality Assessment Program, historical water-quality data have been gathered for the High Plains Regional Ground-Water Study Area into a retrospective data base, which can be used to evaluate the occurrence and distribution of water-quality constituents of concern.

Data from the retrospective data base verify that nitrate, pesticides, and dissolved solids (salinity) are important water-quality concerns in the High Plains study area. Sixteen percent of all measured nitrate concentrations were larger than the U.S. Environmental Protection Agency drinking-water standard of 10 milligrams per liter. In about 70 percent of the counties within the High Plains study area, nitrate concentrations for 1980-98 were significantly larger than for 193069 . While nitrate concentrations are largest where depth to water is shallow, concentrations also have increased in the Ogallala Formation where depth to water is large. Pesticide data primarily are available only in the northern half of the study area. About 50 pesticides were detected in the High Plains study area, but only four pesticides (atrazine, alachlor, cyanazine, and simazine) had concentrations exceeding a drinking-water standard. The occasional detection of pesticides in deeper parts of the Ogallala Formation indicates that contamination pathways exist. Dissolved solids, which are a direct measure of salinity, had 29 percent of measured concentrations in excess of the secondary drinking-water standard of 500 milligrams per liter. Comparison of dissolvedsolids concentrations prior to 1980 to concentrations after 1980 indicates dissolved-solids concentrations have increased in the alluvial valleys of the Platte, the Republican, and the Arkansas Rivers, as well as in the Ogallala Formation-South hydrogeologic unit.

Water-quality results indicate that human activities are affecting the water of the High Plains aquifer. Because there is a potential for water quality to become impaired relative to the historical uses of the aquifer, water quality needs to be considered when evaluating the sustainability of the High Plains aquifer. Data collected as part of the High Plains Regional Ground-Water Study will help to fill in gaps in water-quality information and provide additional information for understanding the factors that govern ambient water quality. 


\section{INTRODUCTION}

The High Plains Regional Ground-Water Study Area (also referred to in this report as the High Plains study area) encompasses the High Plains aquifer, which underlies 174,000 square miles in parts of eight States (fig. 1). The High Plains aquifer includes the well-known Ogallala Formation and is an important national resource, providing water for agriculture in an otherwise dry landscape. About 27 percent of the irrigated land in the United States is in the High Plains study area, and about 30 percent of the ground water used for irrigation in the United States is pumped from the High Plains aquifer (Dennehy, 2000). Irrigation is the dominant water use, with irrigation withdrawals during 1995 totaling more than 15 billion gallons per day (U.S. Geological Survey National Water Information System data base). However, the aquifer also provides drinking water for 82 percent of the 2.3 million people who live within the study area boundary (Dennehy, 2000).

Substantial pumping of the High Plains aquifer for irrigation since about the 1940's has resulted in water-level declines in some parts of the aquifer of more than 100 feet (McGuire and Sharpe, 1997). Concern about these declines and the sustainability of the aquifer led the U.S. Congress in 1984 to mandate a water-level monitoring program for the aquifer. Water quality of the aquifer is a more recent concern. States and local governmental entities have done local studies on water quality, but no comprehensive assessment has been made of the entire aquifer. The U.S. Geological Survey (USGS) National Water-Quality Assessment (NAWQA) Program is an ongoing effort to document water-quality conditions across the United States, and the High Plains Regional GroundWater Study was instituted as part of NAWQA in 1998. One of the first elements of NAWQA studies is a retrospective assessment of available water-quality information. This report summarizes the results of the compilation and assessment of historical water-quality data for the study area.

\section{Purpose and Scope}

The purpose of this report is to describe and assess historical (1930-98) water-quality data for the High Plains study area. This retrospective assessment gives an indication of where data are present or lacking and helps define the temporal and geographic extent of water-quality concerns, thereby providing a framework for the NAWQA study design. In this report, the compilation of historical data is described, including sources of data, data-base design, screening procedures and quality assurance of data, and characteristics of the resulting data base. The data base is included in digital form as a companion to this report. Statistical summaries are presented for selected constituents in the data base. Finally, for some constituents, temporal and spatial variability in concentrations is described, and variability is examined relative to human and environmental factors that might affect concentrations.

\section{Acknowledgments}

The task of locating and assembling ancillary and water-quality data for the eight-State study area would not have been possible without the assistance of many individuals. The author would like to thank the employees of the various governmental agencies who provided information used in this report. A complete listing of these agencies is provided (see table 4), but the author would especially like to acknowledge Patrick Larson and Mary Exner of the University of Nebraska and Janie Hopkins of the Texas Water Development Board for their assistance in making available large water-quality data sets from the States of Nebraska and Texas.The author also would like to thank USGS employees for their assistance: Christi V. Hansen and Joan Kenny in Kansas; Judith A. Boohar and Jennifer Stanton in Nebraska; Denis F. Healy in New Mexico; Mark F. Becker and Lyn K. Osburn in Oklahoma; Michael J. Moran and Michael L. Strobel in South Dakota; Dana L. Barbie, Freeman L. Andrews, and Dee Lurry in Texas; and Deb Trefren and Melanie Clark in Wyoming.

\section{DESCRIPTION OF HIGH PLAINS REGIONAL GROUND-WATER STUDY AREA}

The High Plains occupy the higher elevation parts of the much larger Great Plains physiographic province, which lies between the Rocky Mountains on the west and the Central Lowland on the east. This high area, with elevations ranging from 7,800 feet on 


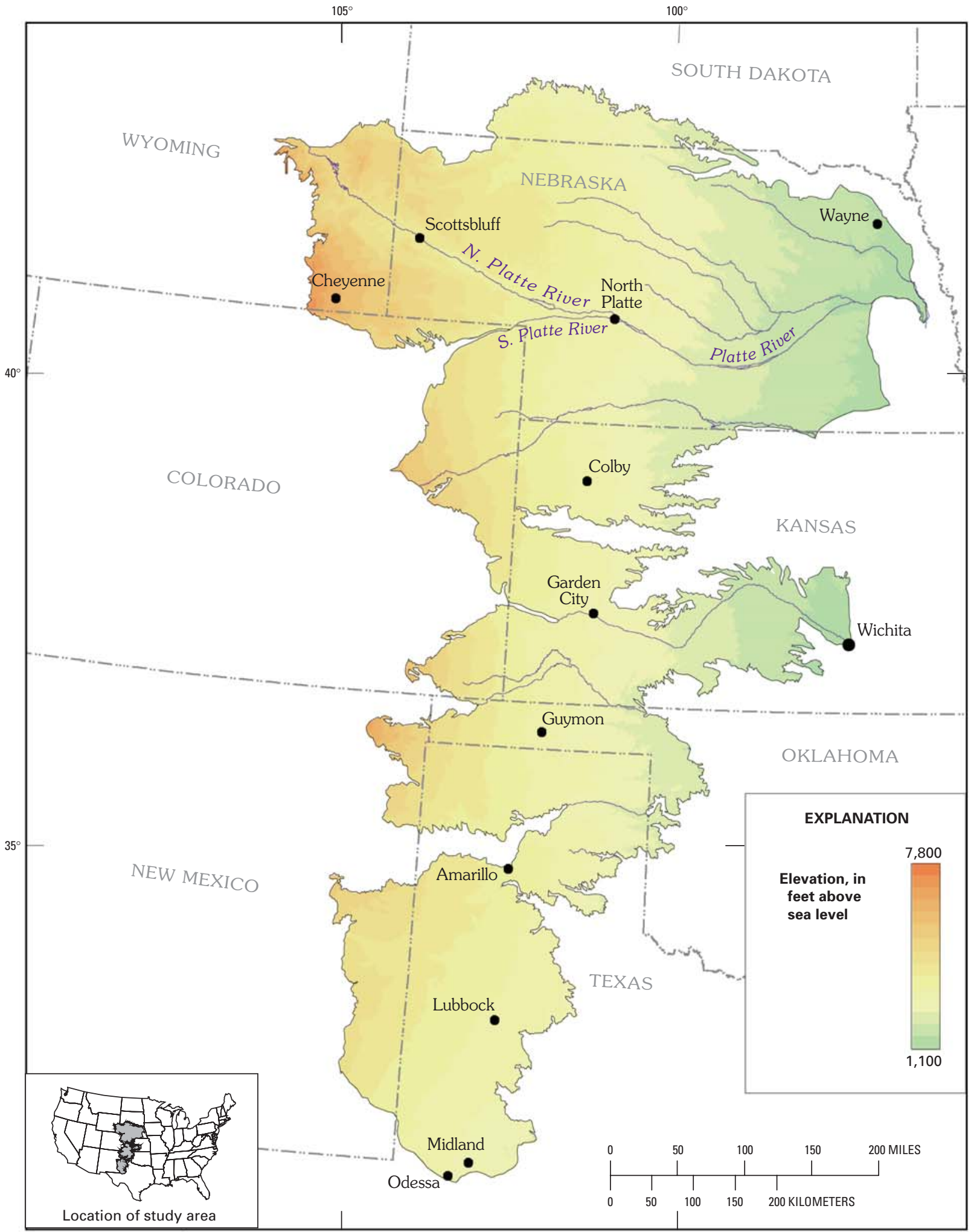

Figure 1. Location of the High Plains Regional Ground-Water Study Area. 
the west to 1,100 feet on the east, is a remnant of a vast plain formed by sediments of Tertiary age that were deposited by streams flowing eastward from the ancestral Rocky Mountains. The boundary of the High Plains is marked in some areas by an escarpment formed by ledges of the resistant cap rock of the Ogallala Formation. The land within the High Plains is characterized by gently sloping, smooth plains with a local topographic relief of less than 300 feet, which is ideal for agricultural use. The climate is dry: mean annual precipitation ranges from 16 inches in the western part of the study area to about 28 inches in the east. Because precipitation is small and slopes are flat, little runoff is available to produce streamflow. Most principal rivers in the study area flow through the High Plains but derive their water primarily from the Rocky Mountains to the west. Natural vegetation in this shortgrass prairie area was grama-buffalo grass, and the natural precipitation supports only droughttolerant crops such as wheat.

A vast ground-water reservoir underlying the High Plains was described as early as 1901 (Johnson, 1901), but at that time the well technology was lacking to bring this deep water to the surface. Beginning in the 1930's, advances in well technology made deeper wells feasible. Development of the High Plains aquifer started in Texas, where depths to water were small, and expanded northward. During 1949-78, irrigated acreage in the High Plains increased from about 2 million acres to 13 million acres, and ground-water pumpage increased from about 4 million acre-feet to 23 million acre-feet (Gutentag and others, 1984). The High Plains aquifer currently (2000) sustains the economy and population of the region by providing water for irrigation and public water supplies.

These large changes in land use and water use have increased the complexity of the water budget of the High Plains study area. Prior to development, water fluxes were relatively small and in dynamic equilibrium. The total volume of drainable water in storage in the High Plains aquifer was equivalent to a column of water about 30 feet deep across the 174,000-square-mile extent of the aquifer (Gutentag and others, 1984). Precipitation recharged the aquifer at a rate of about 0.6 inch per year (Weeks and others, 1988). Small quantities of water left the aquifer in the form of discharge to springs and streams. Subsequent to development, ground-water pumpage has removed an amount of water equivalent to about 2 feet of water from the aquifer, or about 7 percent of the original total (Dugan and Cox, 1994). However, in addition to removing water from the aquifer, ground-water pumpage has increased the internal cycling of water within the aquifer, with about 2 inches of water pumped from the aquifer each year (U.S. Geological Survey National Water Information System data base, 1999) and as much as 10 percent of that water returning to the aquifer each year (Dugan and Zelt, 2000). Agricultural practices also can increase the rate of recharge to the aquifer; for example, water can more easily percolate downward from fallow fields and from fields where crop growth is at an early stage, as compared to areas covered with natural vegetation. Estimated recharge to the High Plains aquifer in Oklahoma is almost three times as large as it was prior to development of the aquifer (Luckey and Becker, 1999).

The High Plains study area is identical in areal extent to the High Plains water-table (unconfined) aquifer as defined by the U.S. Geological Survey’s Regional Aquifer-System Analysis Program (Weeks and others, 1988). The principal geologic unit of the High Plains aquifer is the Ogallala Formation, which consists of a sequence of unconsolidated clays, silts, sands, and gravels of Tertiary age (2 to 65 million years old). In addition to the Tertiary-age Ogallala Formation, the High Plains aquifer also includes older materials (sandstones and siltstones of the Arikaree and Brule Formations of early Tertiary age in the north part of the study area) and younger Quaternary materials deposited on top of or adjacent to the Ogallala Formation (windblown sands primarily in the Sand Hills of Nebraska; alluvial deposits in central Kansas and along present-day river valleys; and glacial deposits in eastern Nebraska). For summarizing water quality in this report, the High Plains aquifer has been subdivided into eight hydrogeologic units: Ogallala Formation-North, Ogallala Formation-Central, Ogallala Formation-South, Arikaree-Brule Formations, Nebraska Sand Hills, Kansas Quaternary Deposits, Nebraska Quaternary Deposits, and Valley-Fill Alluvium (fig. 2). The Ogallala Formation was subdivided into three hydrogeologic units due to its large geographic extent within the study area. Although the High Plains aquifer has been subdivided into these hydrogeologic units, it is recognized that within the individual units there could be sediments of varying age (Gutentag and others, 1984; Smith, 1940). The individual hydrogeologic units differ in several ways (table 1). The most-used units, as measured by water 


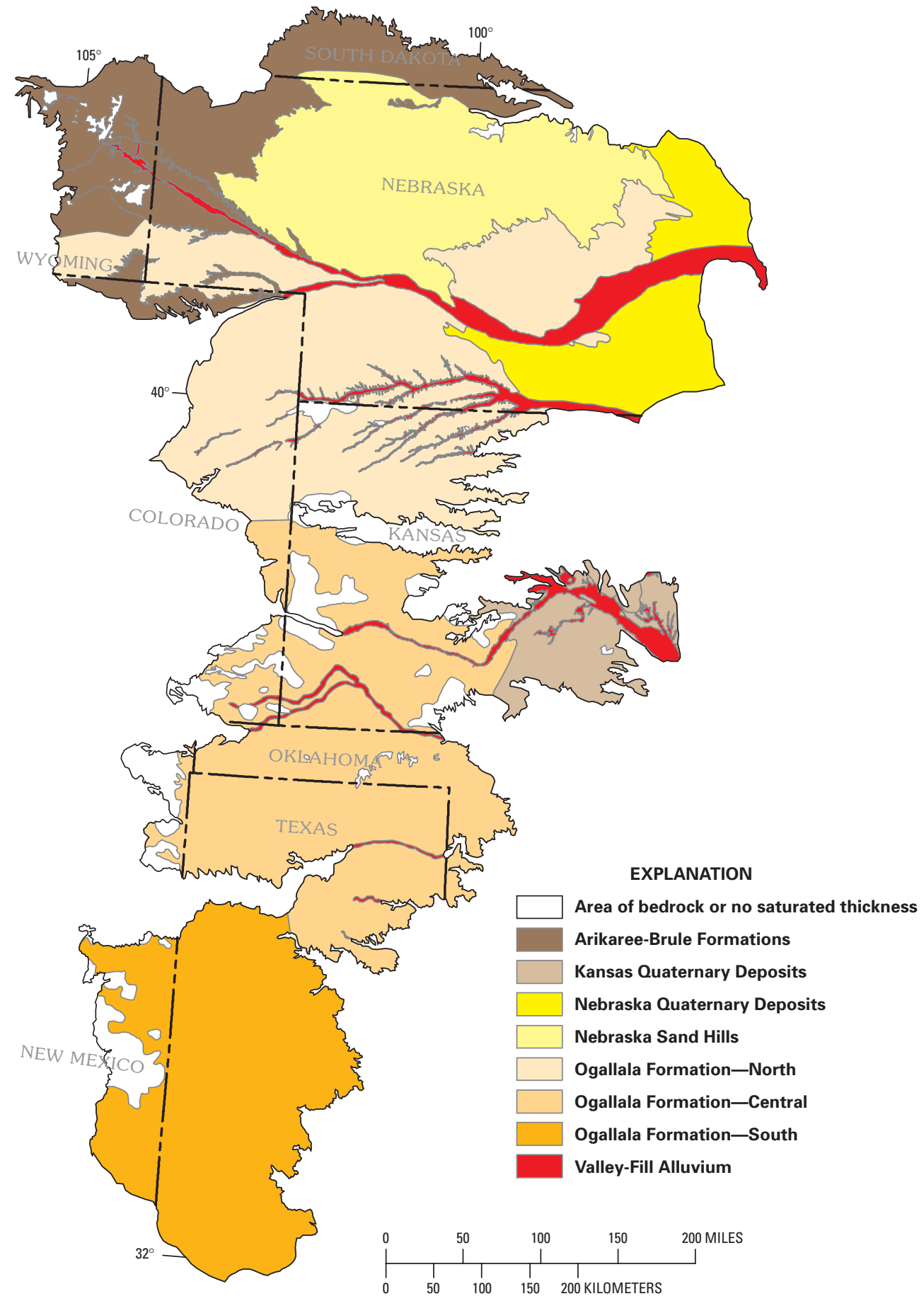

Figure 2. Hydrogeologic units within the High Plains study area. 
Table 1. Selected characteristics of hydrogeologic units within the High Plains study area

[Mgal/d, million gallons per day]

\begin{tabular}{|c|c|c|c|c|c|}
\hline Hydrogeologic unit & $\begin{array}{c}\text { Area } \\
\text { (square } \\
\text { miles) }\end{array}$ & $\begin{array}{c}\text { Estimated } \\
\text { water use in } \\
1995 \\
(\mathbf{M g a l} / \mathbf{d})^{1}\end{array}$ & 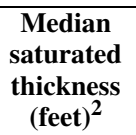 & $\begin{array}{c}\text { Median } \\
\text { depth to } \\
\text { water } \\
\text { (feet) })^{2}\end{array}$ & $\begin{array}{c}\text { Percentage } \\
\text { of area } \\
\text { irrigated }^{3}\end{array}$ \\
\hline Ogallala Formation-North & 37,700 & 2,700 & 110 & 110 & 10 \\
\hline Ogallala Formation-Central & 35,100 & 4,100 & 120 & 160 & 15 \\
\hline Ogallala Formation-South & 27,000 & 4,200 & 60 & 120 & 19 \\
\hline Arikaree-Brule Formations & 19,400 & 480 & 220 & 64 & 5 \\
\hline Nebraska Sand Hills & 22,500 & 700 & 540 & 20 & 5 \\
\hline Kansas Quaternary Deposits & 5,600 & 360 & 87 & 28 & 9 \\
\hline Nebraska Quaternary Deposits & 10,800 & 2,100 & 170 & 79 & 34 \\
\hline Valley-Fill Alluvium & 8,000 & ${ }^{4} 1,000$ & ${ }^{4} 120$ & 18 & 26 \\
\hline
\end{tabular}

use and percentage of irrigated area, are the Nebraska Quaternary Deposits, the Valley-Fill Alluvium, and the three Ogallala Formation units in which the intensity of use increases from north to south. Median depth to water is small and saturated thickness is large in the Nebraska Sand Hills, but water use in this unit is small due to rough topography and sandy soils. Water use is large and median depth to water is small in the ValleyFill Alluvium. In contrast, water use is large and median depth to water is largest for the three Ogallala Formation units.

The environmental setting of the High Plains study area has been described in detail in previous reports (Gutentag and others, 1984; Weeks and others, 1988). For the purposes of this retrospective analysis, selected environmental characteristics were compiled for comparison with water quality. Selection of relevant environmental characteristics was accomplished through a review of previous water-quality studies.

\section{SUMMARY OF PREVIOUS WATER- QUALITY STUDIES}

There are more than 100 references to water quality cited in a bibliography of water-related studies for the High Plains study area that was compiled as part of the NAWQA study (Gerhard Kuhn, U.S. Geological Survey, written commun., 2000). In this bibliography, the most common constituent keyword was nitrate (70 references), followed by dissolved solids (45 references), pesticides (37 references), radiological constituents (23 references), bacteria (13 references), organic compounds (11 references), and trace elements (8 references). The frequency of citation is indicative of the most common water-quality concerns within the High Plains study area.

Water-quality studies have been conducted at scales ranging from regional to site-specific. Because the retrospective data base is aquifer wide, the results of regional studies are more pertinent to this analysis than are site-specific studies. Regional studies are listed in table 2 along with environmental factors found to be related to water quality. Early studies focused on salinity (dissolved solids) because high salinity can affect the use of water for irrigation and because extensive irrigation can lead to increased salinity. Krothe and others (1982) estimated that dissolved-solids concentrations were in excess of 500 milligrams per liter (mg/L) over 19 percent of the area of the High Plains aquifer. Areas of large dissolvedsolids concentrations were primarily related to the underlying bedrock type but also occurred in irrigated alluvial valleys. A study in Texas (Reeves and Miller, 1978) related high salinity to bedrock type and to seepage from playa lakes. This Texas study also was among the first to document large nitrate concentrations, which were related to irrigation intensity and soil properties. A study of ground-water quality in Nebraska (Engberg, 1984) focused on major ions and 
Table 2. Summary of selected water-quality studies conducted within the High Plains study area

\begin{tabular}{|c|c|c|c|c|c|c|c|c|c|}
\hline \multirow{3}{*}{$\begin{array}{c}\text { Reference } \\
\text { (Area of study in parentheses) }\end{array}$} & \multicolumn{9}{|c|}{ Environmental characteristic related to water quality } \\
\hline & \multicolumn{4}{|c|}{ Site-specific characteristic } & \multicolumn{5}{|c|}{ Geographic characteristic } \\
\hline & $\begin{array}{l}\text { Well } \\
\text { depth }\end{array}$ & $\begin{array}{l}\text { Depth to } \\
\text { water }\end{array}$ & $\begin{array}{l}\text { Age } \\
\text { of well }\end{array}$ & $\begin{array}{c}\text { Well } \\
\text { construction }\end{array}$ & $\begin{array}{l}\text { Land } \\
\text { use }\end{array}$ & $\begin{array}{l}\text { Chemical } \\
\text { application } \\
\text { rate }\end{array}$ & $\begin{array}{l}\text { Irriga- } \\
\text { tion } \\
\text { intensity }\end{array}$ & $\begin{array}{l}\text { Soil } \\
\text { proper- } \\
\text { ties }\end{array}$ & $\begin{array}{l}\text { Bedrock } \\
\text { type }\end{array}$ \\
\hline \multicolumn{10}{|c|}{ REGIONAL STUDIES } \\
\hline $\begin{array}{l}\text { Center for Disease Control and } \\
\text { Prevention, } 1998 \\
\text { (Midwestern States) }\end{array}$ & $\mathrm{X}$ & & $\mathrm{X}$ & $\mathrm{X}$ & & & & & \\
\hline $\begin{array}{l}\text { Krothe and others, } 1982 \\
\text { (High Plains) }\end{array}$ & & & & $\mathrm{X}$ & & & $\mathrm{X}$ & & $\mathrm{X}$ \\
\hline $\begin{array}{l}\text { Nolan and others, } 1997 \\
\text { (Nationwide) }\end{array}$ & & & & & & $\mathrm{X}$ & & $\mathrm{X}$ & \\
\hline \multicolumn{10}{|c|}{ STATEWIDE WITHIN HIGH PLAINS } \\
\hline Engberg, 1984 (Nebraska) & & $\mathrm{X}$ & & & & & & $\mathrm{X}$ & $\mathrm{X}$ \\
\hline $\begin{array}{l}\text { Exner and Spalding, } 1990 \\
\text { (Nebraska) }\end{array}$ & & $\mathrm{X}$ & & $\mathrm{X}$ & & & $\mathrm{X}$ & $\mathrm{X}$ & \\
\hline $\begin{array}{l}\text { Druliner and others, } 1996 \\
\text { (Nebraska) }\end{array}$ & $\mathrm{X}$ & $\mathrm{X}$ & $\mathrm{X}$ & & & & $\mathrm{X}$ & $\mathrm{X}$ & \\
\hline $\begin{array}{l}\text { Gosselin and others, } 1997 \\
\text { (Nebraska) }\end{array}$ & $\mathrm{X}$ & $\mathrm{X}$ & $\mathrm{X}$ & $\mathrm{X}$ & & $\mathrm{X}$ & & $\mathrm{X}$ & \\
\hline $\begin{array}{l}\text { Helgesen and others, } 1994 \\
\text { (Kansas) }\end{array}$ & & & & & $\mathrm{X}$ & & & & \\
\hline Hopkins, 1993 (Texas) & & $\mathrm{X}$ & & & & & & & \\
\hline Nativ, 1988 (Texas, New Mexico) & & & & & & $\mathrm{X}$ & & & $\mathrm{X}$ \\
\hline Perry and others, 1988 (Kansas) & & & & & & $\mathrm{X}$ & & $\mathrm{X}$ & \\
\hline Reeves and Miller, 1978 (Texas) & & & & & & & $\mathrm{X}$ & $\mathrm{X}$ & $\mathrm{X}$ \\
\hline Spalding, 1991 (Nebraska) & $\mathrm{X}$ & & $\mathrm{X}$ & $\mathrm{X}$ & & & & & \\
\hline $\begin{array}{l}\text { Steichen and others, } 1988 \\
\text { (Kansas) }\end{array}$ & & & $\mathrm{X}$ & & $\mathrm{X}$ & & & & \\
\hline
\end{tabular}

dissolved solids but listed nitrate as the most pervasive potential problem constituent. In the late 1980's, water-quality surveys began to document widespread occurrences of elevated nitrate concentrations. A survey of farmstead wells in Kansas (Steichen and others, 1988) reported nitrate in excess of the U.S. Environmental Protection Agency drinking-water maximum contaminant level (MCL) in 28 percent of wells sampled; and a compilation of data in Nebraska (Exner and Spalding, 1990) reported the nitrate MCL exceeded in 20 percent of the wells sampled. These studies attributed large nitrate concentrations both to site-specific factors (depth to water, well construction, age of well) and to broader geographic factors (irrigation intensity, land use, soil properties). However, statistical correlations between nitrate and explanatory variables often were poor due to the large variability in environments across large geographic areas and due to a mixed population of wells affected by point sources and of wells affected by nonpoint sources. A study restricted to nonpoint-source contamination in the High Plains aquifer in Nebraska (Druliner and others, 1996) found significant relations between nitrate concentrations and age of well (likely indicative of longer histories of chemical application), irrigation intensity, and soil permeability. A study restricted to nonpoint-source contamination in the High Plains aquifer of Kansas (Helgesen and others, 1994) found land use to be a statistically significant variable relative to nitrate concentrations. Recent regional studies (Center for Disease Control and Prevention, 1998; Nolan and others, 1997) have confirmed that ground water in the High Plains area is susceptible to nitrate contamination.

Surveys of the occurrence of pesticides in ground water began appearing in about 1990 for 
Kansas (Steichen and others, 1988), Texas (Aurelius, 1989), and Nebraska (Exner and Spalding, 1990).

Pesticide studies historically have been constrained by analytical considerations (high cost of analysis, large detection limits, and lack of analytical techniques for pesticides of interest). These early studies generally reported pesticide detections in only a small proportion of sampled wells, with large concentrations of pesticides occurring rarely; but the documentation of pesticide occurrence in ground water was important because it showed that synthetic chemicals did migrate into aquifers. Pesticide properties such as water solubility, degradation half-life, and soil sorption index were recognized to cause the mobility of pesticides in the environment to differ from nitrate and from each other. Atrazine, one of the most heavily used pesticides, has chemical properties favorable for mobility in the environment; as a result, atrazine has documented occurrence rates as large as 13 percent of wells sampled (Exner and Spalding, 1990). However, occurrence rates in Kansas and Nebraska were found to be highly variable, based on regional environmental conditions. Given the complexity of pesticide mobility in the environment, many recent studies have focused on farm-field scale examinations of pesticide movement (see, for example, Sophocleous and others, 1990).

Despite the smaller geographic scope of previous water-quality studies, the findings of these studies can help guide the analysis of High Plains retrospective data. The historical studies show that water quality has changed in the High Plains NAWQA study area; the studies also indicate which waterquality constituents are of most concern. Historical studies suggest that stratification of study areas into smaller, more homogeneous areas is useful for data analysis and provide insights into selection of environmental factors that may affect water quality.

\section{SOURCES AND CHARACTERISTICS OF AVAILABLE WATER-QUALITY DATA}

Data compiled for this retrospective analysis include ground-water-quality data available in digital format for 1930-98. A data survey was conducted during the summer of 1998. Employees of the USGS in each of the eight States within the High Plains study area contacted Federal, State, and local agencies to identify available data. As a result of this effort, 67 ground-water-quality data sets were inventoried. Water-quality data sets ranged in scope from small spreadsheet data sets for specific projects maintained by local agencies to large, comprehensive data sets from multiple agency sources compiled by State and Federal agencies. The large, comprehensive data sets were preferentially acquired because they included many of the smaller agency data sets and because data quality was previously evaluated. Data sets were not acquired if they were not available in digital format.

\section{Data-Selection Criteria and Screening Procedures}

Minimum requirements were established for inclusion of data into the retrospective data base to ensure compatibility of data for analysis. Location of the well, aquifer source, sampling date, and description of each water-quality constituent were required.

Location of the well, in the form of latitude and longitude, was required to enable geographic analysis of water-quality data. The accuracy of location varied depending on the method of determination, and when known, an accuracy code was assigned to each well location. About 75 percent of the sites have good location accuracy (accurate within 300 feet).

An indication of the aquifer source of the sampled water was required. The most straightforward indication of water source was an assigned aquifer for the well. For wells without an assigned aquifer, welldepth information was required. The aquifer source of sampled water was then deduced on the basis of the location of the well relative to the eight defined hydrogeologic unit boundaries, supplemented by comparison of well depth with geographic information system (GIS) information about elevation of the bottom of the aquifer.

For water-quality measurements, a sampling date was required. Measurements in the data base go back as far as 1930. In some cases, only the year of the sampling was known, and these were arbitrarily assigned a date of January 1 for the year of sampling. In other cases, only a year and month were known; these samples were arbitrarily assigned a sampling date of the 15th of the month. A time of sampling was not required; where a time was missing, a value of -9999 was coded for time. For water-quality measurements, a specific description for each constituent also was required so that each measurement could be 
assigned a parameter code from the USGS parameter code dictionary (Garcia and others, 1997).

Additional data fields were included in the database design to provide more complete information about sites and water-quality measurements, but information for these fields was not required for inclusion of data into the data base. Additional information available about sites includes land-surface datum, primary water use, date of well completion, casing material, and aquifer and well openings information. Additional information available about water-quality measurements includes data quality, data project, and data agency. A more complete description of the tables and fields included in the data base is provided in the Appendix of this report. Detailed information also is provided about the design and use of the retrospective data base. The data base is provided as part of this report on CD-ROM, in both proprietary (Microsoft Access) and nonproprietary (tab-delimited ASCII files) formats.

\section{Quality Assurance of Data}

Each contributing data source is the primary agency providing for the quality assurance of data, and where available, references to these quality-assurance procedures are included in the data base. A dataquality-rating scheme was developed (table 3); in this scheme, each water-quality measurement was assigned a quality rating from 0 to 4 , based on criteria about sampling procedures, field quality-assurance practices, and laboratory analytical methods. Similar schemes are used by the Nebraska Water Sciences Laboratory (Mary Exner, University of Nebraska, written commun., 1999) and the Texas Water Development Board (Nordstrom and Quincy, 1997). In some cases water-quality measurements were assigned a low data-quality rating only because information about field and laboratory methods used was not available.

In addition to quality-assurance checks done by source agencies, additional simple data-verification checks were made on selected data fields in the retrospective data base. Descriptive statistics for constituents were calculated to check for outliers or inconsistent values (for example, large negative water temperatures); where these types of data values were discovered, data were verified or excluded from the data base. Geographic checks were made on ancillary well information by using a GIS; for example, county codes were verified by comparison with a county boundary map, and sites with conflicting location information were excluded from the data base.

\section{Content of Retrospective Data Base}

Eleven data sets were incorporated into the retrospective data base (table 4) representing data collected by 43 agencies. Sixty percent of the data were acquired from Federal agencies (USGS, USEPA, Center for Disease Control and Prevention, U.S. Department of Energy), 30 percent from State agencies (primarily the Nebraska Water Sciences Laboratory and the Texas Water Development Board), and about 10 percent from local agencies (notably the Equus Beds Groundwater Management District No. 2). After screening and quality assurance were completed, the retrospective data base contained 29,041 water-sampling sites, 58,731 ground-waterquality samples, and 1,003,868 observations (in this report, the word observation is used to refer to any physical measurement or analytical result available for a sampled well). About 22,500 of the sites had only

Table 3. Criteria for rating data quality

[USEPA, U.S. Environmental Protection Agency]

\begin{tabular}{cllll}
\hline \multirow{2}{*}{$\begin{array}{c}\text { Quality } \\
\text { rank }\end{array}$} & \multicolumn{1}{c}{ Sampling procedure } & & Data ranking criteria & \\
\cline { 2 - 2 } & & \multicolumn{1}{c}{ Field-quality assurance } & Laboratory-analytical method \\
\hline 0 & Unknown & Unknown & None & Unknown \\
1 & Grab sample & & None or unknown & A USEPA-accepted method \\
2 & Follows accepted sampling procedures & & Fepted method \\
3 & Follows accepted sampling procedures & & Field duplicates or blanks & A USEPA-accepted method \\
4 & Strict sampling protocols & & Field duplicates and blanks & A USEPA-accepted method \\
\hline
\end{tabular}


Table 4. Data sources for the retrospective data base

[NAWQA, National Water-Quality Assessment Program; USEPA, U.S. Environmental Protection Agency]

\begin{tabular}{|c|c|c|c|c|}
\hline Source of data & $\begin{array}{l}\text { Number of } \\
\text { agencies }\end{array}$ & $\begin{array}{l}\text { Number of } \\
\text { sites }\end{array}$ & $\begin{array}{l}\text { Number of } \\
\text { samples }\end{array}$ & $\begin{array}{l}\text { Number of } \\
\text { observations }\end{array}$ \\
\hline Center for Disease Control and Prevention & 1 & 553 & 553 & 2,212 \\
\hline Colorado Department of Public Health and Environment & 1 & 210 & 210 & 8,494 \\
\hline Equus Beds Groundwater Management District No. 2 & 1 & 342 & 3,483 & 30,268 \\
\hline Nebraska Water Sciences Laboratory & 17 & 6,302 & 11,967 & 41,467 \\
\hline New Mexico Environment Department Drinking Water Bureau & 1 & 234 & 2,386 & 70,484 \\
\hline Oklahoma Department of Environmental Quality & 1 & 212 & 347 & 10,766 \\
\hline Texas Water Development Board & 13 & 6,399 & 9,612 & 206,869 \\
\hline U.S. Geological Survey National Water Information System & 1 & 8,453 & 23,284 & 468,894 \\
\hline U.S. Geological Survey, Central Nebraska NAWQA Study & 4 & 1,254 & 1,263 & 38,008 \\
\hline $\begin{array}{l}\text { U.S. Department of Energy by way of U.S. Geological Survey, } \\
\text { Geologic Division }\end{array}$ & 1 & 3,865 & 3,865 & 82,662 \\
\hline USEPA Storage and Retrieval (STORET) data base & 2 & 1,217 & 1,761 & 43,744 \\
\hline TOTAL & 43 & 29,041 & 58,731 & $1,003,868$ \\
\hline
\end{tabular}

one sample collected, but 6,545 sites had more than one sample collected, including 716 sites that had 10 or more samples collected. The number of observations per sample ranged from 1 to 253, with an average of 17. The average number of observations per sample ranged from 3 for sites from the Nebraska Water Sciences Laboratory data set (a pesticide and nitrate data set) to 30 for samples from the New Mexico Environment Department Drinking Water Bureau data set (a finished drinking-water data set) and from the Central Nebraska NAWQA study data set (a comprehensive ambient water-quality data set).

The locations of water-quality sampling sites are shown in figure 3 . Of the 236 counties that intersect with or are included within the study area, 222 have at least one water-quality site. The largest number of sites within a county is 796 for Gaines County, Texas, which is located near the southern boundary of the study area. About one-half the counties in the study area have at least 100 water-quality-sampling sites. Areas with few sampling sites include the Sand Hills area of Nebraska and areas in Colorado, New Mexico, Kansas, and Oklahoma where the saturated thickness of the aquifer is small. Patterns in the location of sampling sites sometimes are indicative of specific projects. For example, the high density of sites in the Wichita, Kansas, area (east-central Kansas) is due to projects investigating salinity in ground water used for water supply. The grid-like pattern of sites in parts of
Nebraska and Kansas is due to sampling done as part of the National Uranium Resource Evaluation (NURE) program (Smith, 1999) of the Department of Energy.

The retrospective data base includes results for 733 parameters. These can be grouped according to constituent or measurement type, and the number of observations in the data base for each group for the years 1950 to 1998 is shown in figure 4 . The most common parameter group is the major ions (77 parameters; 369,111 observations). This group includes the primary substances dissolved in water that contribute to dissolved solids (salinity), such as sodium, calcium, chloride, and sulfate. There are at least 2,000 observations for major ions for every year from 1950 to 1998. The second most common parameter group is physical measurements (28 parameters; 136,040 observations), which include properties of water such as dissolved oxygen, $\mathrm{pH}$, specific conductance, water temperature, and suspended solids. The temporal pattern for physical measurements is similar to that of major ions but with fewer observations because there are fewer parameters in this group. The third most common group is trace elements (58 parameters; 116,072 observations). However, the temporal pattern of traceelement observations is different than the pattern for major ions and physical measurements; most observations occurred after 1960 and during only a few years, in particular during 1977-79, when data were collected as part of the NURE program. Data for the 


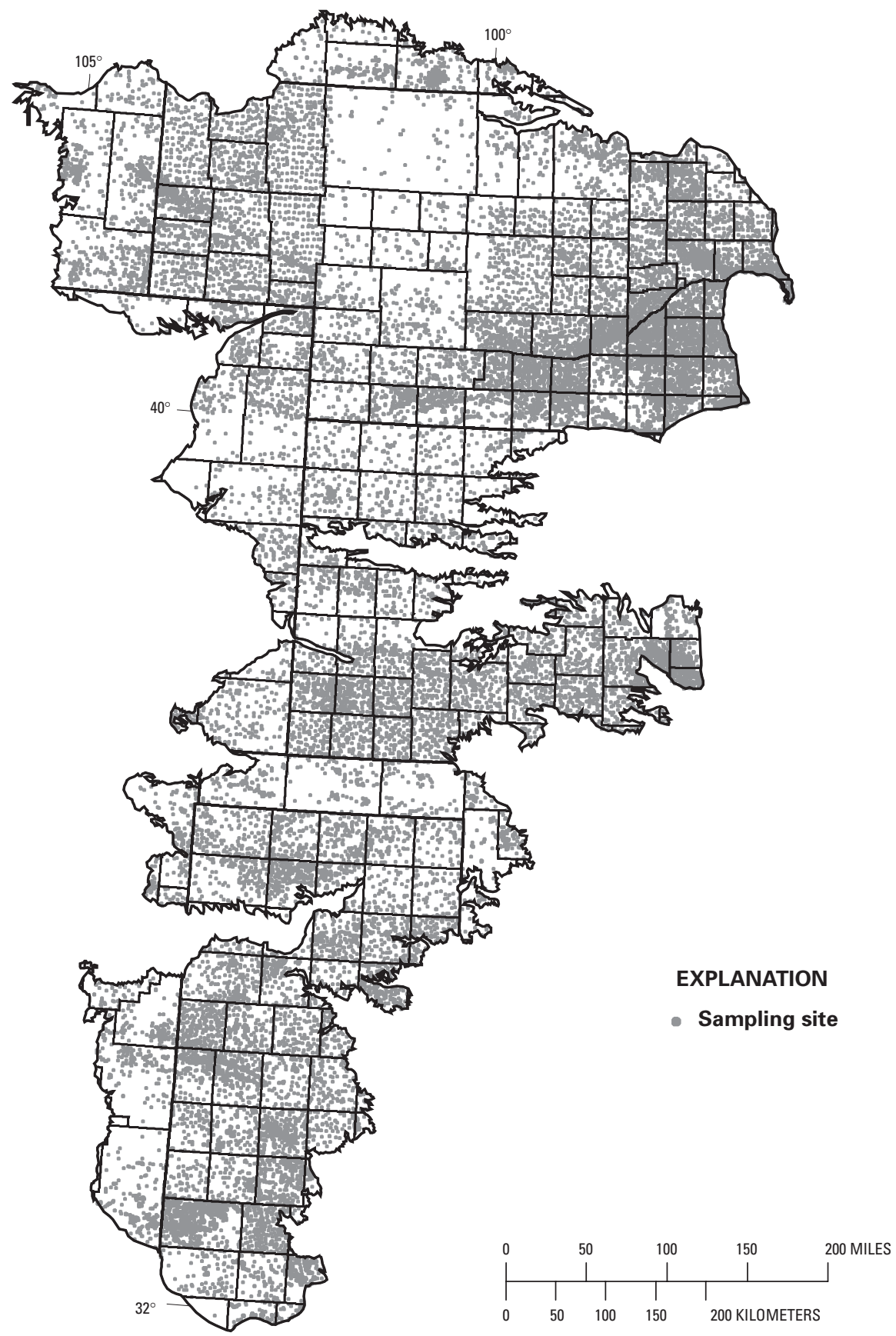

Figure 3. Location of sampling sites in the High Plains retrospective data base.

nutrients group, which includes nitrate, have generally increased from about 1960 to the present, except for the large number of observations in the late 1970's. The pesticides and volatile organic compounds groups include the largest number of parameters and have similar numbers of total observations (about 90,000); however, few data were available for these groups prior to 1985 . Few data exist for radiological param- eters, probably because few laboratories do these analyses and the cost is high. Few data exist for bacteriological parameters in the data base. This group includes coliform bacteria counts, which commonly are determined by public health department laboratories for domestic water-supply wells. However, these data were not incorporated into the retrospective data 

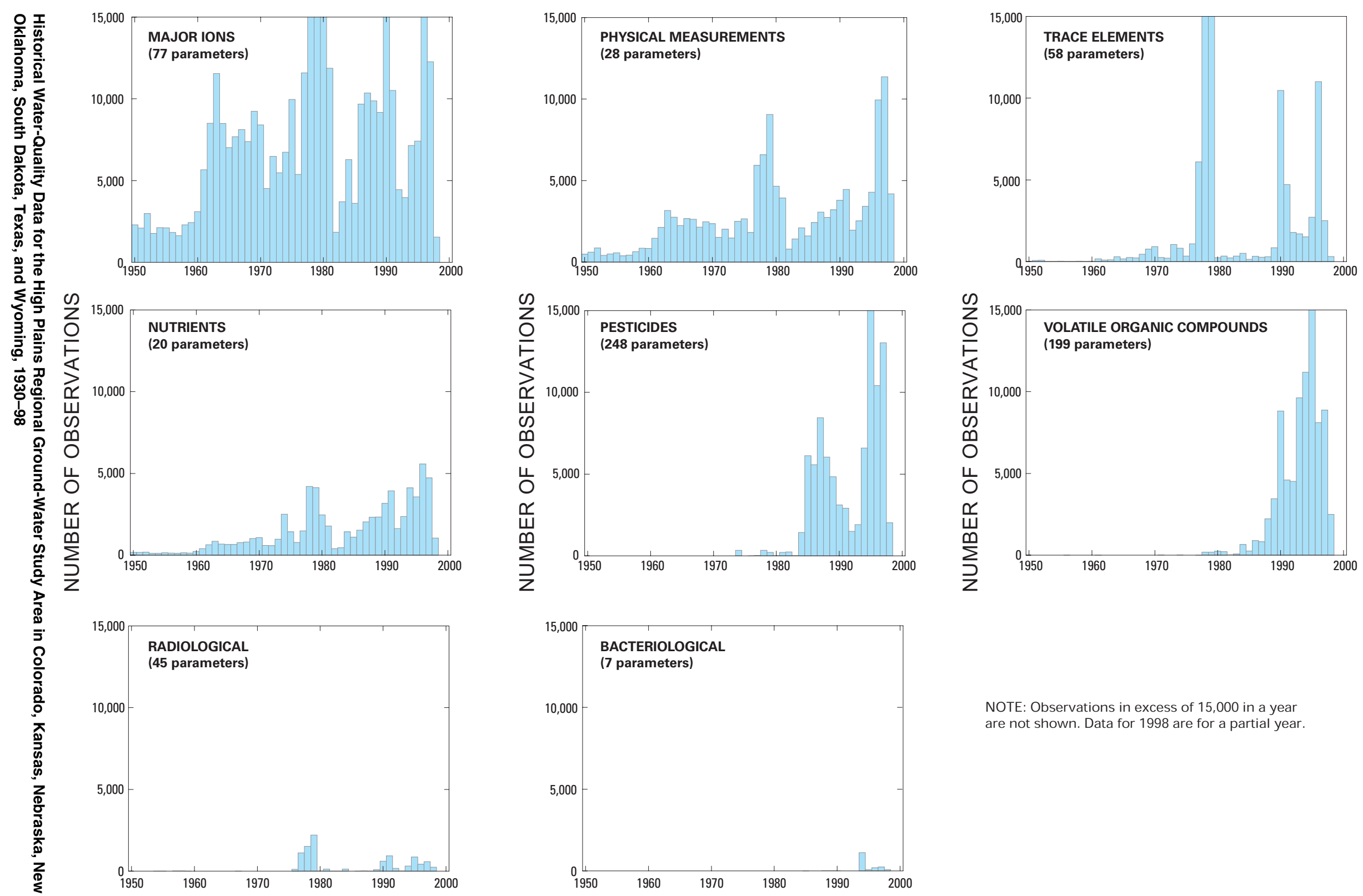

NOTE: Observations in excess of 15,000 in a year are not shown. Data for 1998 are for a partial year.

Figure 4. Temporal distribution of water-quality observations for selected parameter groups, 1950-98. 
base because ancillary information about the sampled well generally was not available.

The geographic distribution of water-quality observations varies among parameter groups (fig. 5). For example, nutrient data are available throughout the study area, but pesticide data exist primarily for Nebraska. Nutrient data generally consist of fewer than 10 observations at a site and often consist of a single nitrate observation. In contrast, pesticide data generally consist of more than 10 observations at a site because pesticides commonly are analyzed in the laboratory as a suite of compounds. For trace-element data, observations are distributed throughout the study area, but sites with 10 or more observations are in areas where NURE data are available. Observations for volatile organic compounds are sparse in the study area and generally are clustered in areas where local studies have been done or where drinking-water monitoring programs exist.

\section{Site Characterization}

Ancillary information about the sampled well sites is included in the data base. In some cases, site information is available that was gathered onsite at the time of sampling or that was acquired by cross reference with well-permit files. This site-specific information generally is the most accurate type of ancillary information, but often is unavailable. The number of sites having various types of site-specific ancillary information is shown in figure 6 . Well depth information was available for 94 percent of the wells; depths ranged from less than 10 feet to 1,703 feet and had a median value of 160 feet. Well-type information was available for 88 percent of the wells; among these, 93 percent were installed for water withdrawal and only 7 percent (1,772 wells) were installed as observation wells. Water-use-type information was available for 90 percent of the wells; among these, 43 percent were used for irrigation, 28 percent were used for domestic water supply, 11 percent were unused, 9 percent were used for livestock, 7 percent were used for public supply, and 2 percent were used for other water uses. About one-third of the sites had information about the age of the well; completion dates ranged from the year 1850 to 1997 . Only about 22 percent of the wells had information about screened interval; therefore, for most water-quality observations there is a lack of information about the precise depth of sampled water.

Two important well characteristics are the aquifer source of water and depth to water, but only 57 percent of the wells had aquifer information and only 33 percent of the wells had a measured depth to water. Ancillary map information was therefore used to provide a more complete data base. Although the High Plains aquifer is the aquifer source, individual hydrogeologic units were assigned to the aquifer data field in the data base. Well-site locations were compared to a map of hydrogeologic units (fig. 2) to assign units to wells that had no site-specific information; this process was automated using an overlay process within a GIS. Assignment of units using this process is reasonable where one unit does not underlie another unit. However, in some parts of the study area the Valley-Fill Alluvium unit or the Nebraska Sand Hills unit is underlain by Ogallala Formation units. Wells in these areas were assumed to be completed in the surficial unit. About half of the wells located in the ValleyFill Alluvium area (fig. 2) were assigned to the ValleyFill Alluvium unit in this way; the median depth of these wells was $60 \mathrm{ft}$. About two-thirds of the wells in the Nebraska Sand Hills area were assigned to the Nebraska Sand Hills unit in this way; the median depth of these wells was $135 \mathrm{ft}$. A GIS process also was used to check whether wells were completed at a level deeper than the bottom of the High Plains geohydrologic units. A depth-to-bedrock surface was generated by the GIS, using data for wells from the High Plains Water-Level Monitoring Network (Sharon Qi, USGS, written commun., 1999). Wells whose depths were substantially greater than the depth-to-bedrocksurface value were assigned to bedrock aquifers and excluded from the water-quality data analysis.

Using similar GIS techniques, depth to water was assigned to the 67 percent of wells that had no site-specific information. A depth-to-water surface (fig. 7) was generated in the GIS by using 1997 waterlevel information for wells from the High Plains Water-Level Monitoring Network (Sharon Qi, U.S. Geological Survey, written commun., 1999). To verify the accuracy of this method, site-specific depth-towater information (available for 33 percent of the wells) was compared with the 1997 GIS depth-towater surface; the median difference between these values was 22 percent. Depths to water estimated in this way ranged from less than 10 feet to 495 feet, with a median value of 67 feet. 


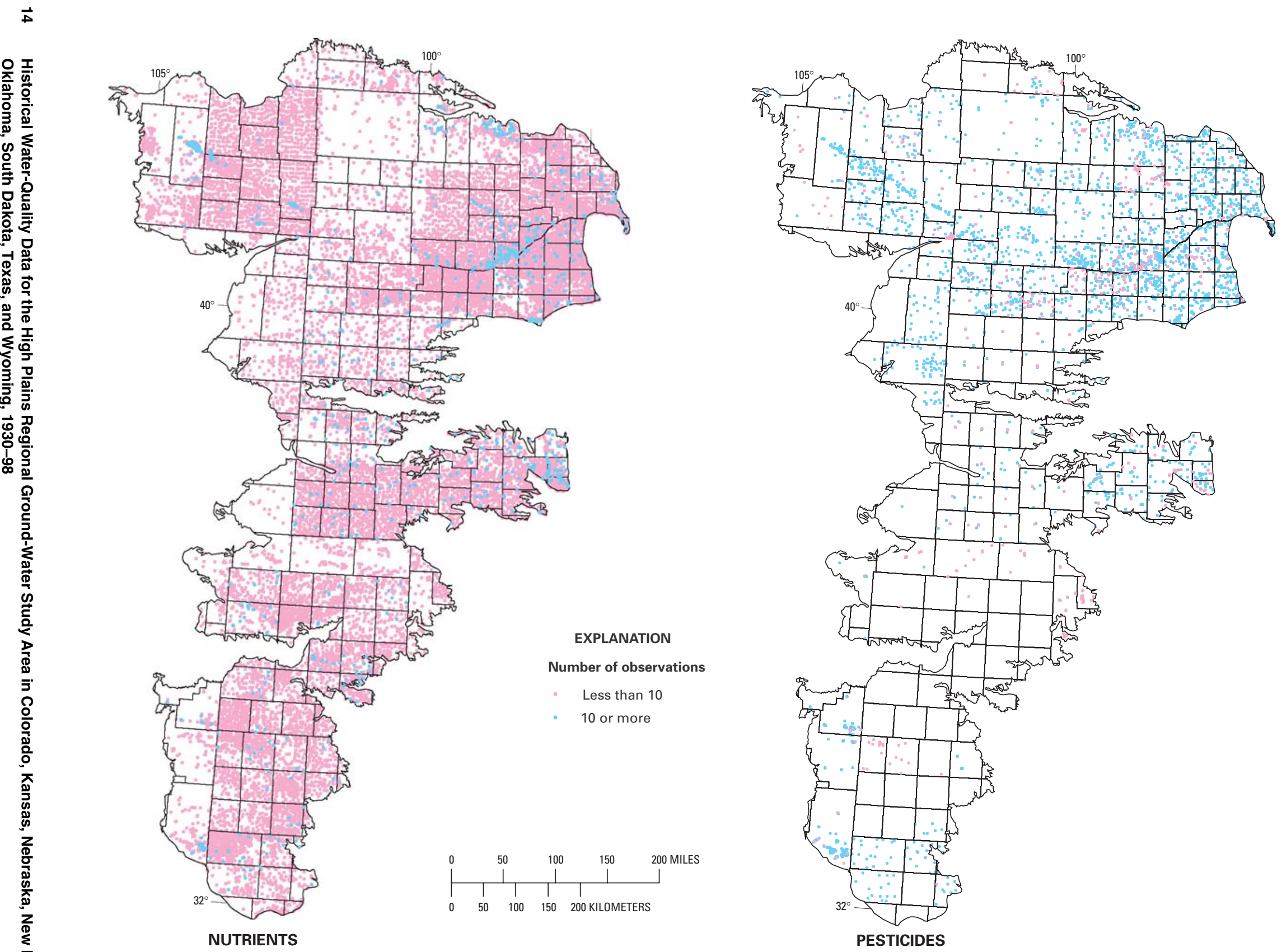

Figure 5. Geographic distribution of observations for nutrients, pesticides, trace elements, and volatile organic compounds. 


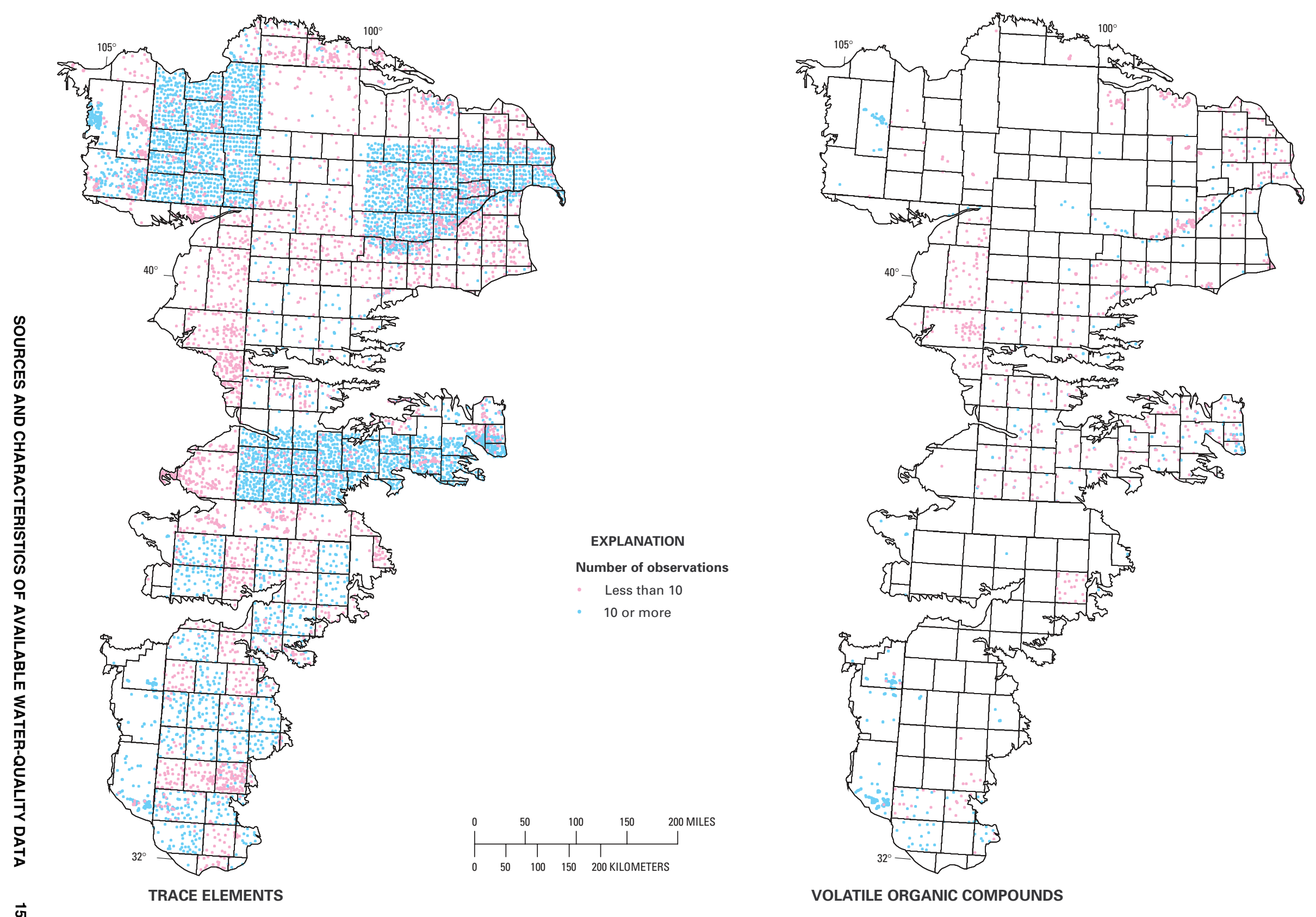

Figure 5. Geographic distribution of observations for nutrients, pesticides, trace elements, and volatile organic compounds-Continued. 


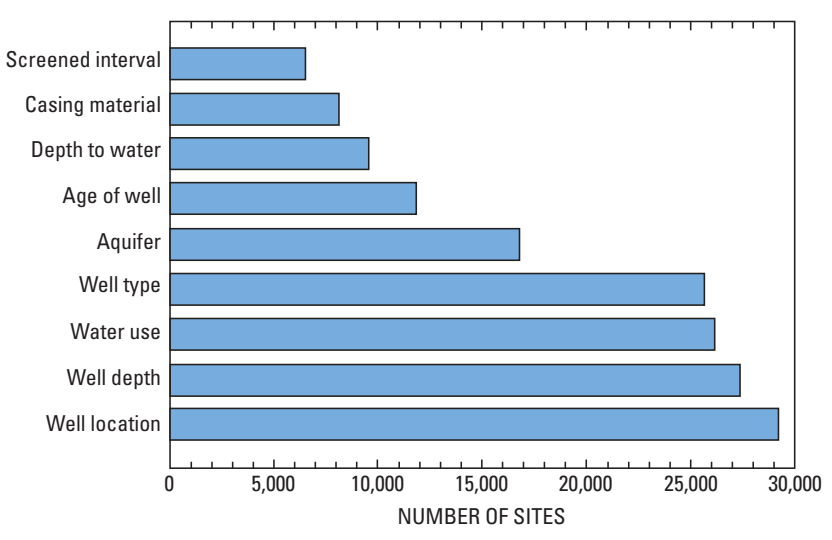

Figure 6. Number of sites with selected site-specific information.

Characteristics determined by previous studies to be important to water quality (see tables 2 and 5) were assigned to wells by using GIS map information. Land use was mapped for the United States during the early 1980's at a resolution of about 10 acres for agricultural land (Fegeas and others, 1983) and remains the only detailed nationwide data set for land use for the United States. These land-use data, called GIRAS (Geographic Information Retrieval and Analysis System) data, were available for most of the study area, and 75 percent of the wells were assigned a land use by using this data set; among these wells, 73 percent were in agricultural land use, 19 percent were in rangeland, 6 percent were in urban land use, and 2 percent were in other land uses. Irrigation is an especially relevant part of agricultural land use, and the location of irrigated lands in the study area was most recently determined in 1980 as part of the USGS High Plains Regional Aquifer-System Analysis (RASA) project (Thelin and Heimes, 1987), in which irrigation was reported as the percentage of irrigated land in 1-square-mile cells across the study area (fig. 8); the total irrigated area is 22,800 square miles (14.5 million acres). Irrigation intensity was assigned to retrospective wells by use of this RASA data set, and values ranged from no irrigated lands at a well to 99 percent irrigated land, with a median value of 19 percent irrigated land.

Agricultural land use is an important source of nitrogen to the land surface, with inputs from manure and fertilizer applications (fig. 9). County manure nitrogen-application rates can be estimated (Puckett and others, 1998) based on agricultural census counts of the number of animals in each county. Manure is generally applied to the land surface within 50 miles of where it is generated due to transportation costs. Manure application rates are relatively uniform because farm animals are generally widespread across the High Plains; counties with the largest rates generally are those where large cattle feedlots are located. County fertilizer nitrogen-application rates have been estimated (David Lorenz, U.S. Geological Survey, written commun., 1999) based on agricultural census data about fertilizer sales. In the High Plains study area, fertilizer nitrogen application rates are larger than manure nitrogen application rates. Fertilizer is applied to large contiguous areas in the High Plains study area, which relate to areas of high irrigation intensity. Fertilizer application rates are large in areas where corn is grown because corn has the largest nitrogen requirement among crops grown in the High Plains. To construct a variable representative of these nitrogen inputs, the manure and fertilizer input rates for each county were summed, and this total input rate was assigned to each sampled well in the county. Total nitrogen application rates among sites in the retrospective data base ranged from 1.2 pounds per acre to 142 pounds per acre, with a median value of 46 pounds per acre. These rates are normalized to total county area rather than county crop area, so the application rate on fields may be several times larger, depending on the percentage of the county that is cultivated.

Soil type is an important part of site characterization because soil properties can affect the rates at which chemicals move though soils into the underlying aquifers. A nationwide soils data set (called STATSGO) from the U.S. Department of Agriculture (U.S. Department of Agriculture, 1991) includes a variable called Soil Hydrologic Group, which is a measure of infiltration rates through soils and drainage characteristics. To characterize retrospective data sites, the Soil Hydrologic Group variable was transformed into an area-weighted numeric variable ranging in value from 1 to 4 where 1 represents soils with low infiltration rates and 4 represents soils with high infiltration rates. Among retrospective sites, the infiltration variable ranged from 1.0 to 4.0 with a median value of 2.94, which indicates that High Plains soils generally have moderately high infiltration rates. The geographic distribution of infiltration rates is shown in figure 10; for this figure, an infiltration variable value of 1 to 2 is classified as low, a value from 2.01 to 3 is classified as medium, and a value from 3.01 to 4 is classified as high. 


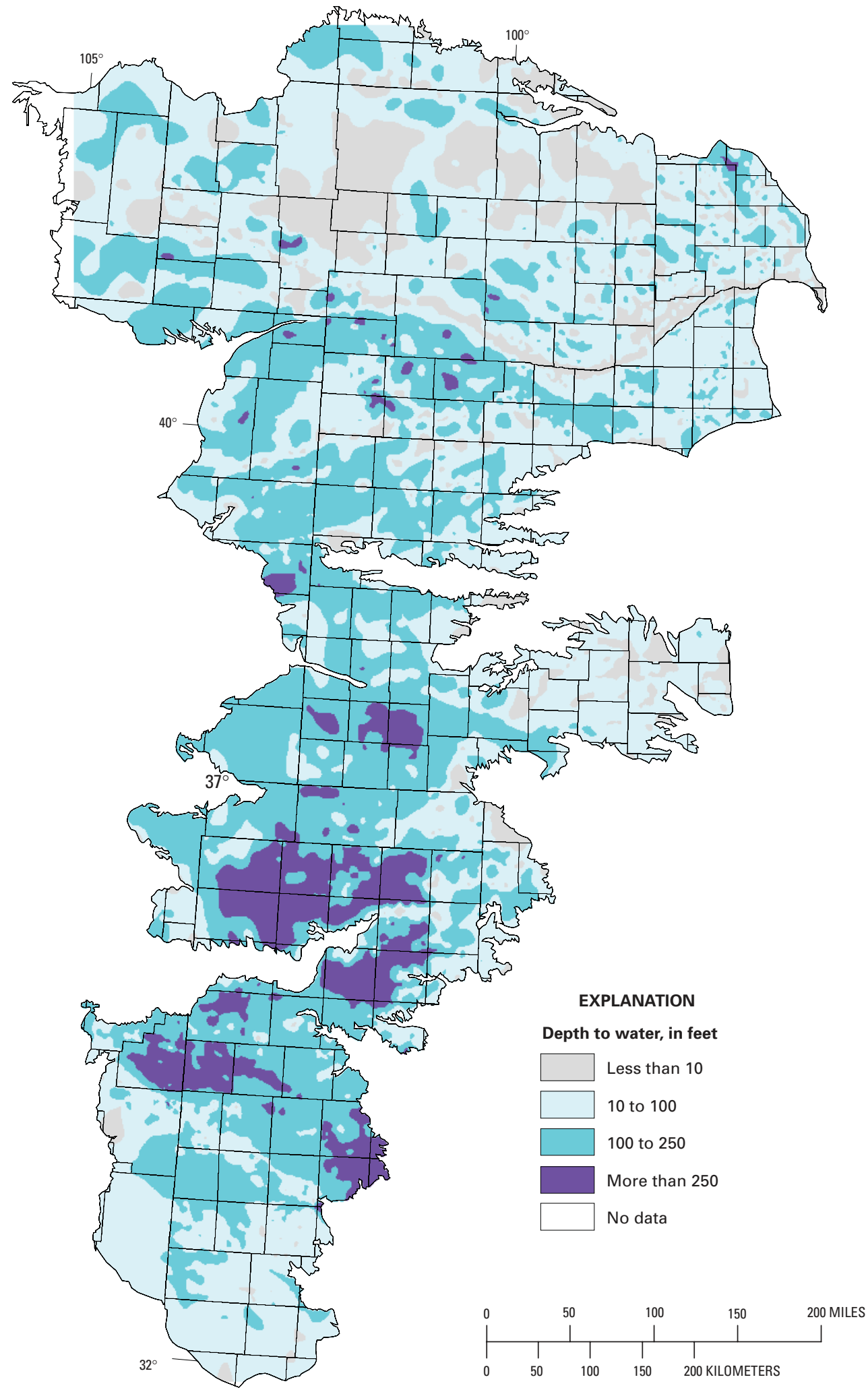

Figure 7. Depth to water during 1997 in the High Plains study area. 
Table 5. Geographic characteristics assigned to sites by using a geographic information system

\begin{tabular}{lll}
\hline \multicolumn{1}{c}{$\begin{array}{c}\text { Geographic } \\
\text { characteristic }\end{array}$} & \multicolumn{1}{c}{ Data source type } & \multicolumn{1}{c}{ Reference } \\
\hline Hydrogeologic unit & 1:500,000 scale map & Weeks and others (1988). \\
Depth to water in 1997 & Interpolated surface & Sharon Qi, U.S. Geological Survey, written commun., 1999. \\
Land use & $1: 250,000$ scale map & Fegeas and others (1983). \\
Irrigation intensity & LANDSAT imagery & Thelin and Heimes (1987). \\
Nitrogen application rate & County data & Fertilizer: David Lorenz, U.S. Geological Survey, written commun., 1999; \\
& & manure: Puckett, and others (1998). \\
Soil infiltration rate & $1: 250,000$ scale map & U.S. Department of Agriculture (1991). \\
Underlying bedrock & $1: 1,000,000$ scale map & Weeks and Gutentag (1981). \\
\hline
\end{tabular}

Underlying bedrock type is an important site characteristic because water from underlying bedrock can migrate into High Plains aquifers and affect water quality. Information on bedrock age is available from maps published by the High Plains RASA project (Weeks and Gutentag, 1981). Bedrock age ranges from Permian to Tertiary, with older rocks generally in the southern half of the study area. Detailed information has not yet been compiled about the soluble-mineral content of the many bedrock units that underlie the study area, but in general the older rocks contain more soluble minerals than the younger rocks (Krothe and others, 1982). The older rocks generally contain water of moderate to high salinity, in particular the Permianage rocks in central Kansas and in the Texas and Oklahoma panhandles, and the Lower Cretaceous-age rocks in Texas at the southern end of the study area (Krothe and others, 1982). Salinity (dissolved-solids concentration) as large as $33,800 \mathrm{mg} / \mathrm{L}$ has been reported in water from Permian-age rocks in southwest Kansas (Gutentag and others, 1980). Among retrospective sites, about 70 percent are underlain by bedrock containing lower salinity water, while the remaining 30 percent are underlain by Permian- and Lower Cretaceous-age bedrock containing higher salinity water.

\section{DATA-ANALYSIS METHODS}

This report contains a descriptive summary of historical water-quality data. The extent of data analysis for individual constituents varies with the amount of data available and with the relevance of the individual constituent to human health. Nonparametric descriptive statistics are presented for all the common or relevant constituents represented in the data base.
Data for a smaller subset of constituents are compared with drinking-water regulatory limits. Finally, data for a few constituents historically of primary concern (nitrate, pesticides, dissolved solids) are analyzed in more detail.

Methods used for selecting data from the data base vary depending on the type of data analysis. For each data analysis presented in this report, the selection criteria are listed. Data are selected on the basis of date of sample, parameter code, number of samples per well, location of site, or data quality. The date of sample is relevant depending on whether historical information or recent information is needed. Parameter code is important because for some constituents there are numerous parameter codes which may not be equivalent. For example, there are six parameter codes for nitrate in the data base (table 6), and for a general descriptive analysis these can be aggregated (after adjustment of reporting units) using the assumption that nitrate concentrations in the solid phase are small and nitrite concentrations are negligible. Multiple observations from a single well might be used in a data analysis of temporal variation of a constituent, but only the most recent observation might be used if an average concentration for the aquifer is being calculated. Site location might also be considered when summarizing aquifer water quality to ensure that multiple wells clustered in a small location are not overrepresented relative to the entire aquifer. Finally, observations with a poorer data-quality rating might be included when doing descriptive nonparametric statistics (for which outliers are given less weight) but not included when doing a comparison of concentrations with a water-quality limit (for which individual observations exceeding a limit are important). Dataselection criteria are documented and discussed for each of the data analyses presented in this report. 


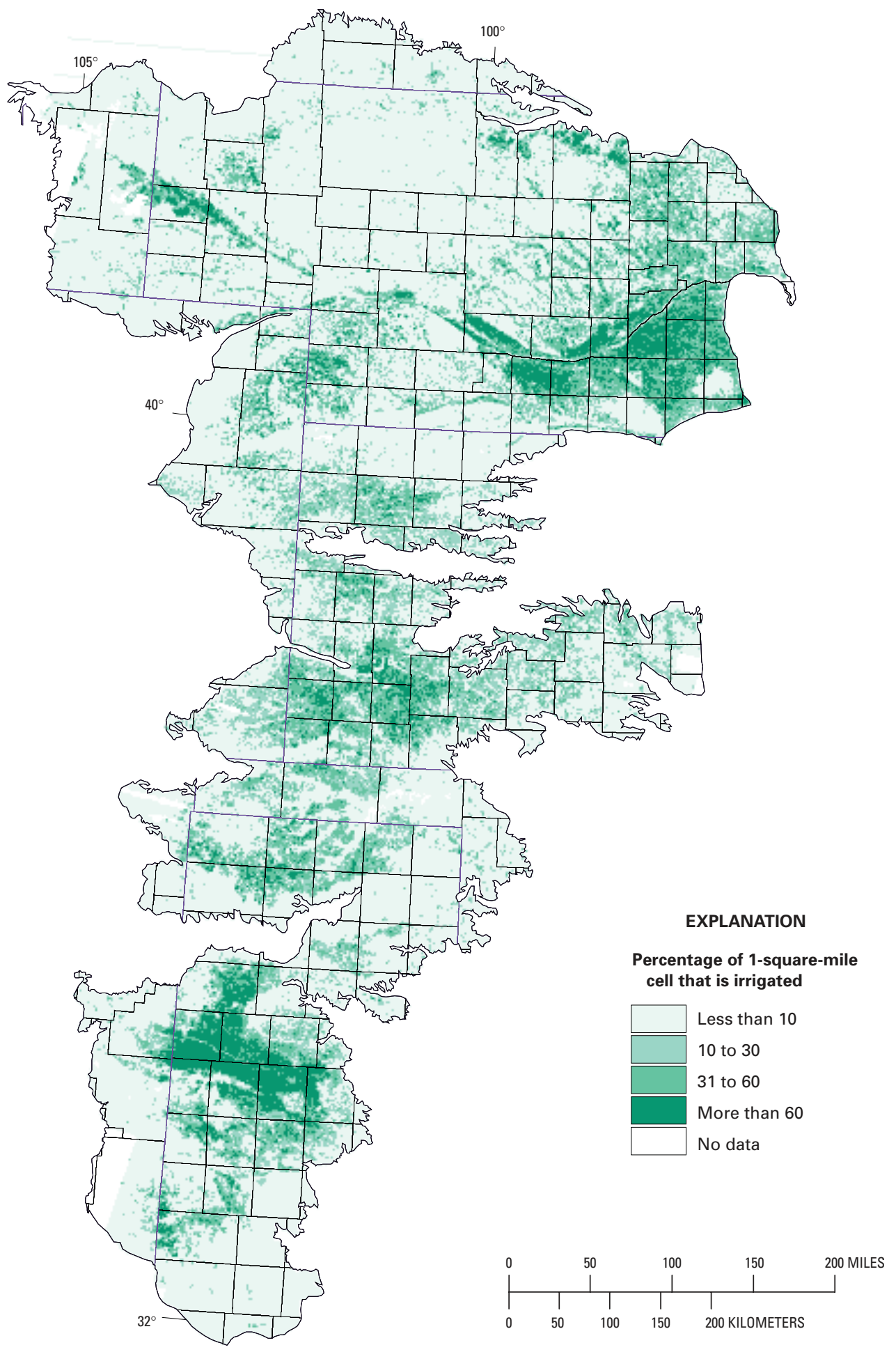

Figure 8. Percentage of land irrigated during 1980 in the High Plains study area. 

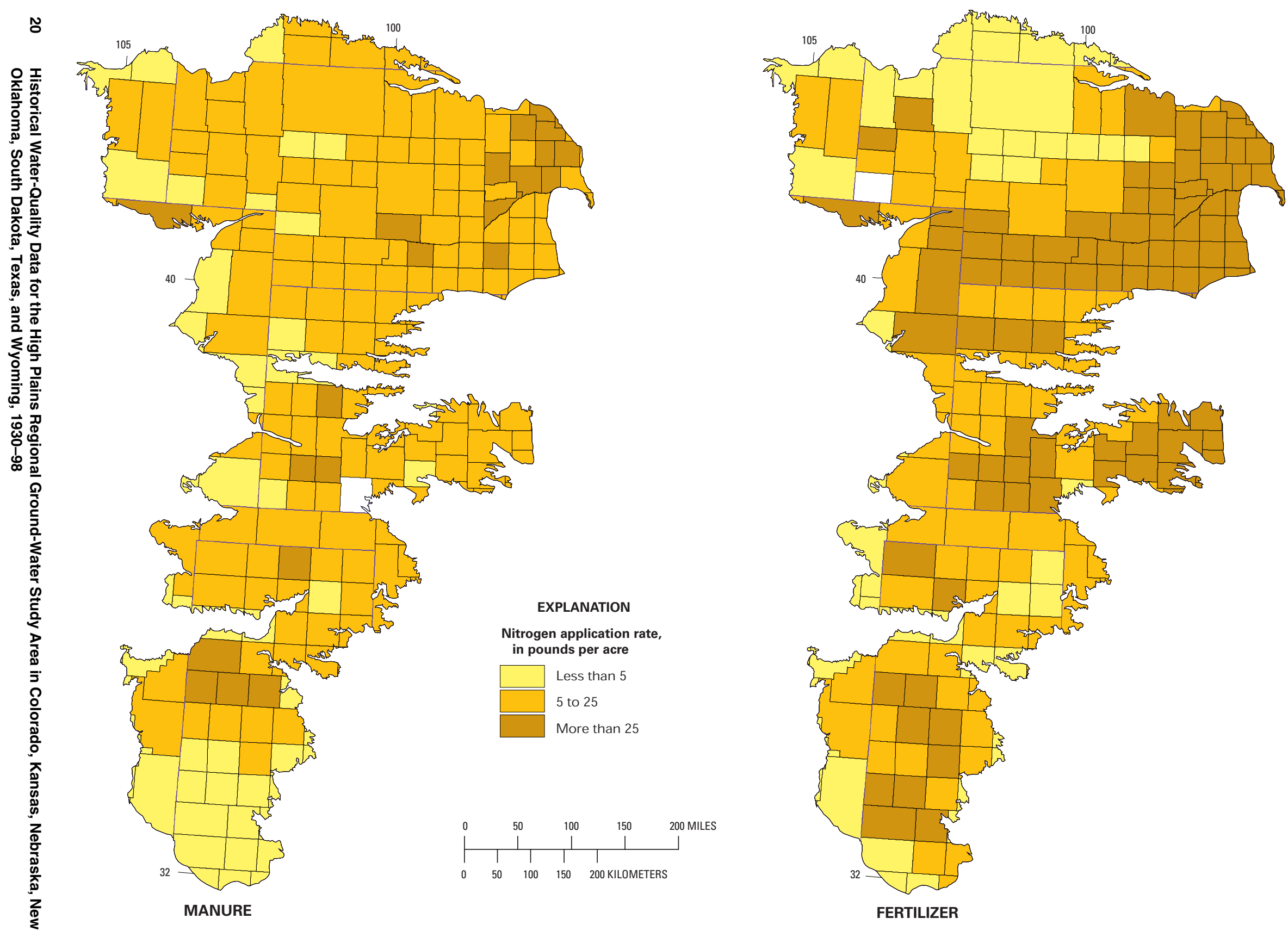

Figure 9. Nitrogen application rates for manure and fertilizer in the High Plains study area, by county, 1992. 


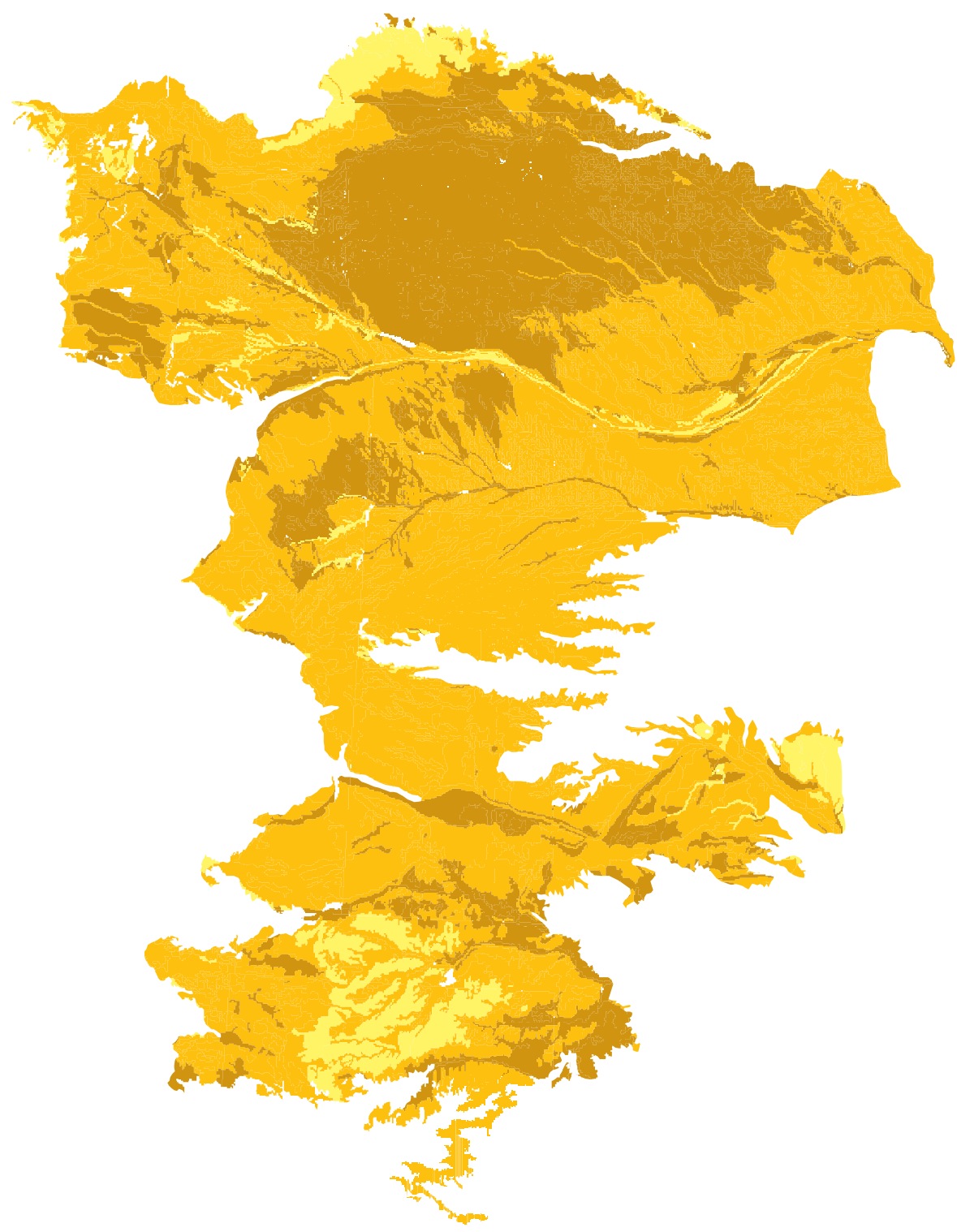


Table 6. Parameter codes for nitrate

\begin{tabular}{cc}
\hline $\begin{array}{c}\text { Parameter } \\
\text { code }^{1}\end{array}$ & Parameter name \\
\hline P00618 & $\begin{array}{c}\text { Nitrate, water, filtered, as nitrogen, milli- } \\
\text { grams per liter. } \\
\text { P00620 } \\
\text { Nitrate, water, unfiltered, as nitrogen, milli- } \\
\text { grams per liter. }\end{array}$ \\
P00630 & $\begin{array}{c}\text { Nitrite plus nitrate, water, unfiltered, as } \\
\text { nitrogen, milligrams per liter. }\end{array}$ \\
& Nitrite plus nitrate, water, filtered, as \\
P00631 & nitrogen, milligrams per liter. \\
& Nitrate nitrogen, total, as nitrate, milli- \\
P71850 & grams per liter. \\
& Nitrogen, nitrate, dissolved, as nitrate, \\
P71851 & milligrams per liter. \\
\hline
\end{tabular}

${ }^{1}$ Parameter codes are from U.S. Geological Survey National Water Information System.

Statistical techniques used for analyses in this report are nonparametric techniques that are suitable for environmental data because environmental data generally are not normally distributed. Nonparametric techniques also are suitable for data with varying data quality because less weight is given to outliers.

Nonparametric techniques used for this report include boxplots, which show the distribution of data; the Kruskal-Wallis (Iman and Conover, 1983),Wilcoxon rank-sum test (Wilcoxon, 1945), and Tukey multiple comparison (Helsel and Hirsch, 1992) tests, which are used to detect differences between groups of data; Lowess smooths (Helsel and Hirsch, 1992), which graphically depict relations between two variables; and rank correlation and regression tests, which measure relations between multiple variables (Helsel and Hirsch, 1992; SAS Institute, 1990). An alpha value of 0.05 was used to evaluate the significance of test results, and in some cases the p-value is also reported to provide information on the level of significance of the statistical test.

\section{ANALYSIS OF HISTORICAL WATER- QUALITY DATA}

From the 733 parameters contained in the retrospective data base, 48 common or relevant constituents were selected for summarization by hydrogeologic unit (table 7). For this table, data were selected for the period 1980-98 so as to be representative of more recent conditions. Multiple parameter codes representing constituents were aggregated, including both filtered- and unfiltered-sample results, except for trace elements, where only filtered-sample results were selected. For some parameter groups, such as pesticides, trace elements, and volatile organic compounds, multiple detection limits were present in the data base. For these constituents, the most common detection limit was selected; observations less than this limit were coded to be nondetections, and nondetections at larger detection limits were not used in the analysis. Where wells had multiple observations for a constituent, only the most recent observation was used. To evaluate the geographic representation of data within each hydrogeologic unit, a grid of cells 10 miles square was overlaid on the study area, and the proportion of cells in each hydrogeologic unit that had data for each constituent was calculated; this proportion is reported in table 7 in the column labeled "Percentage of unit represented." Results in table 7 give a general picture of water quality in the study area. Variability between hydrogeologic units is commonly quite large, which underscores the need to stratify the High Plains aquifer into subunits when describing water quality. The table indicates that data are lacking for many constituents and hydrogeologic units, which validates the need for aquiferwide representative water-quality sampling to better characterize water quality in the aquifer.

Water quality can be evaluated by comparing constituent concentrations to USEPA drinking-water standards (table 8). These standards are relevant because High Plains aquifer water is used as a drinking-water source for 82 percent of the people living within the study area. Water-quality standards generally exist for constituents that have been identified as being a concern for human health. Constituents of concern also have been identified as part of the High Plains Regional Ground Water Study by polling interested agencies within the High Plains study area; constituent groups of concern, ranked by number of replies, were: nutrients, trace elements, pesticides, bacteria, radiological parameters, dissolved solids (salinity), and volatile organic compounds. To compare data from the retrospective data base to water-quality standards, data were extracted from the retrospective data base that had a data quality rating of at least 2 .

Within this selected data set, 16 percent of all nitrate observations were larger than the drinkingwater standard of $10 \mathrm{mg} / \mathrm{L}$. Nitrite is the only other nutrient with a drinking-water standard, but nitrite observations in the data set did not exceed the standard of $1 \mathrm{mg} / \mathrm{L}$. Only four pesticides (atrazine, alachlor, 
Table 7. Descriptive statistics for selected constituents or properties, by hydrogeologic unit, 1980-98

[--, data not available; <, less than]

\begin{tabular}{|c|c|c|c|c|c|c|c|}
\hline \multirow{2}{*}{$\begin{array}{l}\text { Constituent or property and } \\
\text { hydrogeologic unit }^{1}\end{array}$} & \multicolumn{5}{|c|}{ Percentile value } & \multirow{2}{*}{$\begin{array}{c}\text { Number } \\
\text { of } \\
\text { obser- } \\
\text { vations }\end{array}$} & \multirow{2}{*}{$\begin{array}{c}\text { Percentage } \\
\text { of unit } \\
\text { represented } \\
\text { (see p. 22) }\end{array}$} \\
\hline & 10th & 25th & 50th & 75th & 90th & & \\
\hline \multicolumn{8}{|c|}{ PHYSICAL MEASUREMENTS } \\
\hline \multicolumn{8}{|c|}{ Specific conductance, in microsiemens per centimeter, at $25^{\circ}$ Celsius } \\
\hline Ogallala Formation-North & 292 & 339 & 468 & 590 & 776 & 626 & 70 \\
\hline Ogallala Formation-Central & 407 & 461 & 526 & 620 & 869 & 1,287 & 58 \\
\hline Ogallala Formation—South & 540 & 622 & 906 & 1,610 & 3,000 & 2,134 & 80 \\
\hline Arikaree-Brule Formations & 310 & 365 & 540 & 828 & 1,070 & 414 & 37 \\
\hline Nebraska Sand Hills & 97 & 142 & 200 & 381 & 515 & 286 & 38 \\
\hline Kansas Quaternary Deposits & 270 & 350 & 526 & 832 & 1,970 & 267 & 63 \\
\hline Nebraska Quaternary Deposits & 410 & 500 & 600 & 731 & 935 & 776 & 99 \\
\hline Valley-Fill Alluvium & 514 & 719 & 1,000 & 1,390 & 2,510 & 1,143 & 91 \\
\hline \multicolumn{8}{|l|}{$\mathrm{pH}$, in standard units } \\
\hline Ogallala Formation—North & 7.0 & 7.2 & 7.4 & 7.7 & 7.9 & 691 & 72 \\
\hline Ogallala Formation—Central & 7.2 & 7.4 & 7.6 & 7.9 & 8.2 & 1,327 & 63 \\
\hline Ogallala Formation—South & 7.2 & 7.4 & 7.7 & 8.1 & 8.3 & 2,185 & 80 \\
\hline Arikaree-Brule Formations & 7.3 & 7.4 & 7.6 & 7.9 & 8.1 & 454 & 40 \\
\hline Nebraska Sand Hills & 6.6 & 7.0 & 7.3 & 7.6 & 7.8 & 287 & 38 \\
\hline Kansas Quaternary Deposits & 6.8 & 7.1 & 7.4 & 7.7 & 8.2 & 204 & 61 \\
\hline Nebraska Quaternary Deposits & 6.8 & 6.9 & 7.1 & 7.3 & 7.5 & 809 & 99 \\
\hline Valley-Fill Alluvium & 6.9 & 7.1 & 7.4 & 7.8 & 8.2 & 1,030 & 92 \\
\hline \multicolumn{8}{|l|}{ Dissolved oxygen, in milligrams per liter } \\
\hline Ogallala Formation-North & 0.2 & 2.9 & 5.4 & 7.2 & 8.6 & 72 & 13 \\
\hline Ogallala Formation-Central & -- & -- & -- & -- & -- & 6 & 1 \\
\hline Ogallala Formation-South & -- & -- & -- & -- & -- & 0 & 0 \\
\hline Arikaree-Brule Formations & 1.2 & 4.2 & 6.1 & 7.5 & 9.7 & 270 & 21 \\
\hline Nebraska Sand Hills & 0.3 & 0.4 & 1.8 & 5.8 & 9.2 & 90 & 8 \\
\hline Nebraska Quaternary Deposits & 0.4 & 2.2 & 5.9 & 7.8 & 9.0 & 284 & 52 \\
\hline Kansas Quaternary Deposits & -- & -- & -- & -- & -- & 0 & 0 \\
\hline Valley-Fill Alluvium & 0.1 & 0.2 & 1.7 & 5.0 & 6.7 & 310 & 47 \\
\hline \multicolumn{8}{|l|}{ Water temperature, in degrees Celsius } \\
\hline Ogallala Formation-North & 12.5 & 13.5 & 14.9 & 15.5 & 17.0 & 509 & 65 \\
\hline Ogallala Formation-Central & 16.0 & 17.0 & 18.0 & 19.0 & 20.0 & 949 & 57 \\
\hline Ogallala Formation—South & 17.0 & 18.0 & 19.0 & 20.0 & 21.0 & 1,190 & 75 \\
\hline Arikaree-Brule Formations & 12.0 & 12.5 & 13.5 & 15.0 & 16.5 & 380 & 35 \\
\hline Nebraska Sand Hills & 11.5 & 12.0 & 12.5 & 13.2 & 14.0 & 260 & 36 \\
\hline Kansas Quaternary Deposits & 14.4 & 15.0 & 15.5 & 16.5 & 19.3 & 156 & 61 \\
\hline Nebraska Quaternary Deposits & 12.0 & 12.5 & 13.0 & 14.0 & 15.0 & 796 & 99 \\
\hline Valley-Fill Alluvium & 12.0 & 12.5 & 13.5 & 15.0 & 16.5 & 744 & 91 \\
\hline
\end{tabular}

Nitrite, in milligrams per liter as $\mathrm{N}$

Ogallala Formation-North

$<0.01$

NUTRIENTS

$<0.01<0.01$

$<0.01$

$<0.01$

56

11 
Table 7. Descriptive statistics for selected constituents or properties, by hydrogeologic unit, 1980-98-Continued

[--, data not available; <, less than]

\begin{tabular}{|c|c|c|c|c|c|c|c|}
\hline \multirow{2}{*}{$\begin{array}{l}\text { Constituent or property and } \\
\text { hydrogeologic unit }^{1}\end{array}$} & \multicolumn{5}{|c|}{ Percentile value } & \multirow{2}{*}{$\begin{array}{c}\text { Number } \\
\text { of } \\
\text { obser- } \\
\text { vations }\end{array}$} & \multirow{2}{*}{$\begin{array}{l}\text { Percentage } \\
\text { of unit } \\
\text { represented } \\
\text { (see p. 22) }\end{array}$} \\
\hline & 10th & 25th & 50th & 75th & 90th & & \\
\hline
\end{tabular}

\begin{tabular}{|c|c|c|c|c|c|c|c|}
\hline \multicolumn{8}{|c|}{ NUTRIENTS—Continued } \\
\hline Ogallala Formation-Central & $<0.01$ & $<0.01$ & $<0.01$ & $<0.01$ & $<0.01$ & 181 & 20 \\
\hline Ogallala Formation—South & $<0.01$ & $<0.01$ & $<0.01$ & $<0.01$ & $<0.01$ & 226 & 47 \\
\hline Arikaree-Brule Formations & $<0.01$ & $<0.01$ & $<0.01$ & $<0.01$ & $<0.01$ & 152 & 12 \\
\hline Nebraska Sand Hills & $<0.01$ & $<0.01$ & $<0.01$ & $<0.01$ & $<0.01$ & 19 & 5 \\
\hline Kansas Quaternary Deposits & $<0.01$ & $<0.01$ & $<0.01$ & 0.012 & 0.020 & 10 & 3 \\
\hline Nebraska Quaternary Deposits & $<0.01$ & $<0.01$ & $<0.01$ & $<0.01$ & $<0.01$ & 62 & 51 \\
\hline Valley-Fill Alluvium & $<0.01$ & $<0.01$ & $<0.01$ & $<0.01$ & 0.030 & 264 & 38 \\
\hline \multicolumn{8}{|c|}{ Nitrite plus nitrate, in milligrams per liter as $\mathrm{N}$} \\
\hline Ogallala Formation—North & 1.1 & 1.9 & 2.8 & 4.6 & 8.9 & 1,787 & 91 \\
\hline Ogallala Formation-Central & 0.6 & 1.3 & 2.1 & 3.2 & 5.6 & 1,468 & 65 \\
\hline Ogallala Formation-South & 0.6 & 1.2 & 2.5 & 5.4 & 11.1 & 2,249 & 80 \\
\hline Arikaree-Brule Formations & 0.8 & 1.6 & 3.6 & 7.1 & 12.0 & 939 & 59 \\
\hline Nebraska Sand Hills & 0.3 & 0.9 & 2.4 & 7.8 & 15.1 & 840 & 82 \\
\hline Kansas Quaternary Deposits & 0.1 & 2.2 & 5.4 & 9.3 & 15.7 & 302 & 67 \\
\hline Nebraska Quaternary Deposits & 0.5 & 1.9 & 4.3 & 7.8 & 12.9 & 3,325 & 100 \\
\hline Valley-Fill Alluvium & 0.1 & 0.8 & 4.0 & 10.6 & 20.0 & 2,544 & 100 \\
\hline \multicolumn{8}{|l|}{ Ammonia, in milligrams per liter as $\mathrm{N}$} \\
\hline Ogallala Formation—North & $<0.010$ & $<0.010$ & 0.015 & 0.045 & 0.244 & 93 & 16 \\
\hline Ogallala Formation—Central & $<0.010$ & $<0.010$ & 0.020 & 0.020 & 0.030 & 353 & 36 \\
\hline Ogallala Formation—South & $<0.010$ & $<0.010$ & $<0.010$ & 0.020 & 0.140 & 435 & 54 \\
\hline Arikaree-Brule Formations & $<0.010$ & 0.015 & 0.015 & 0.027 & 0.055 & 183 & 15 \\
\hline Nebraska Sand Hills & $<0.010$ & $<0.010$ & $<0.010$ & $<0.010$ & 0.040 & 39 & 7 \\
\hline Kansas Quaternary Deposits & $<0.010$ & $<0.010$ & $<0.010$ & 0.063 & 0.138 & 38 & 28 \\
\hline Nebraska Quaternary Deposits & $<0.010$ & $<0.010$ & 0.020 & 0.090 & 0.542 & 63 & 51 \\
\hline Valley-Fill Alluvium & $<0.010$ & 0.015 & 0.020 & 0.044 & 0.130 & 364 & 51 \\
\hline \multicolumn{8}{|c|}{ Ammonia plus organic nitrogen, in milligrams per liter as $\mathrm{N}$} \\
\hline Ogallala Formation-North & $<0.20$ & $<0.20$ & 0.40 & 0.50 & 0.60 & 29 & 9 \\
\hline Ogallala Formation—Central & $<0.20$ & $<0.20$ & $<0.20$ & $<0.20$ & $<0.20$ & 306 & 23 \\
\hline Ogallala Formation—South & $<0.20$ & $<0.20$ & $<0.20$ & 0.24 & 0.50 & 494 & 55 \\
\hline Arikaree-Brule Formations & $<0.20$ & $<0.20$ & 0.22 & 0.35 & 0.52 & 64 & 4 \\
\hline Nebraska Sand Hills & 0.24 & 0.30 & 0.50 & 0.60 & 2.28 & 43 & 7 \\
\hline Kansas Quaternary Deposits & -- & -- & -- & -- & -- & -- & -- \\
\hline Nebraska Quaternary Deposits & $<0.20$ & 0.25 & 0.40 & 0.60 & 1.22 & 13 & 11 \\
\hline Valley-Fill Alluvium & $<0.20$ & $<0.20$ & 0.40 & 0.80 & 1.30 & 118 & 22 \\
\hline \multicolumn{8}{|l|}{ Phosphorus, in milligrams per liter as $\mathrm{P}$} \\
\hline Ogallala Formation-North & $<0.01$ & $<0.01$ & 0.02 & 0.05 & 0.12 & 68 & 13 \\
\hline Ogallala Formation-Central & $<0.01$ & $<0.01$ & $<0.01$ & 0.03 & 0.09 & 139 & 24 \\
\hline Ogallala Formation-South & -- & -- & -- & -- & -- & -- & -- \\
\hline Arikaree-Brule Formations & $<0.01$ & $<0.01$ & 0.02 & 0.05 & 0.07 & 78 & 12 \\
\hline Nebraska Sand Hills & 0.03 & 0.05 & 0.09 & 0.14 & 0.21 & 57 & 8 \\
\hline Kansas Quaternary Deposits & $<0.01$ & 0.04 & 0.06 & 0.09 & 0.13 & 59 & 39 \\
\hline Nebraska Quaternary Deposits & -- & -- & -- & -- & -- & 5 & 6 \\
\hline Valley-Fill Alluvium & 0.02 & 0.03 & 0.06 & 0.14 & 0.28 & 196 & 47 \\
\hline
\end{tabular}


Table 7. Descriptive statistics for selected constituents or properties, by hydrogeologic unit, 1980-98-Continued

[--, data not available; <, less than]

\begin{tabular}{|c|c|c|c|c|c|c|c|}
\hline \multirow{2}{*}{$\begin{array}{l}\text { Constituent or property and } \\
\text { hydrogeologic unit }^{1}\end{array}$} & \multicolumn{5}{|c|}{ Percentile value } & \multirow{2}{*}{$\begin{array}{c}\text { Number } \\
\text { of } \\
\text { obser- } \\
\text { vations }\end{array}$} & \multirow{2}{*}{$\begin{array}{c}\text { Percentage } \\
\text { of unit } \\
\text { represented } \\
\text { (see p. 22) }\end{array}$} \\
\hline & 10th & 25th & 50th & 75th & 90th & & \\
\hline \multicolumn{8}{|c|}{ NUTRIENTS-Continued } \\
\hline \multicolumn{8}{|c|}{ Orthophosphorus, in milligrams per liter as $\mathrm{P}$} \\
\hline Ogallala Formation—North & $<0.01$ & $<0.01$ & 0.05 & 0.12 & 0.19 & 71 & 15 \\
\hline Ogallala Formation-Central & $<0.01$ & $<0.01$ & $<0.01$ & $<0.01$ & 0.06 & 191 & 28 \\
\hline Ogallala Formation-South & $<0.01$ & $<0.01$ & 0.07 & 0.12 & 0.16 & 186 & 41 \\
\hline Arikaree-Brule Formations & $<0.01$ & 0.02 & 0.03 & 0.05 & 0.20 & 92 & 11 \\
\hline Nebraska Sand Hills & $<0.01$ & 0.08 & 0.12 & 0.17 & 0.31 & 14 & 5 \\
\hline Kansas Quaternary Deposits & $<0.01$ & 0.03 & 0.05 & 0.08 & 0.12 & 97 & 43 \\
\hline Nebraska Quaternary Deposits & 0.02 & 0.06 & 0.17 & 0.23 & 0.30 & 63 & 51 \\
\hline Valley-Fill Alluvium & $<0.01$ & 0.02 & 0.04 & 0.08 & 0.16 & 312 & 47 \\
\hline \multicolumn{8}{|c|}{ Organic carbon, in milligrams per liter as C } \\
\hline Ogallala Formation-North & 0.2 & 0.4 & 0.7 & 4.5 & 7.4 & 16 & 5 \\
\hline Ogallala Formation-Central & 0.2 & 0.3 & 0.5 & 1.3 & 4.3 & 16 & 4 \\
\hline Ogallala Formation—South & -- & -- & -- & -- & -- & -- & -- \\
\hline Arikaree-Brule Formations & -- & -- & -- & -- & -- & 2 & 1 \\
\hline Nebraska Sand Hills & 0.6 & 0.9 & 1.3 & 2.2 & 3.0 & 125 & 9 \\
\hline Kansas Quaternary Deposits & 0.3 & 0.4 & 0.9 & 2.4 & 11.0 & 25 & 20 \\
\hline Nebraska Quaternary Deposits & -- & -- & -- & -- & -- & -- & -- \\
\hline Valley-Fill Alluvium & 0.7 & 1.1 & 1.7 & 2.5 & 3.8 & 110 & 27 \\
\hline
\end{tabular}

Alachlor, in micrograms per liter

Ogallala Formation-North

Ogallala Formation-Central

Ogallala Formation-South

Arikaree-Brule Formations

Nebraska Sand Hills

Kansas Quaternary Deposits

Nebraska Quaternary Deposits

Valley-Fill Alluvium

Atrazine, in micrograms per liter

Ogallala Formation-North

Ogallala Formation-Central

Ogallala Formation-South

Arikaree-Brule Formations

Nebraska Sand Hills

Kansas Quaternary Deposits

Nebraska Quaternary Deposits

Valley-Fill Alluvium

Carbaryl, in micrograms per liter

Ogallala Formation-North

Ogallala Formation-Central

Ogallala Formation-South

Arikaree-Brule Formations
$<0$

$<0.5$

$<0.5$

$<0.5$

$<0.5$

$<0.5$

$<0.5$

$<0.5$

$<0.1$

$<0.1$

$-$

$<0.1$

$<0.1$

$<0.1$

$<0.1$

$<0.1$

$<2.5$

$-$

$--$

$<2.5$
$<0.5$

$<0.5$

$<0.5$

$<0.5$

$<0.5$

$<0.5$

$<0.5$

$<0.5$

$<0.1$

$<0.1$

$--$

$<0.1$

$<0.1$

$<0.1$

$<0.1$

$<0.1$

$<2.5$

$-$

$--$

$<2.5$

PESTICIDES

$\begin{array}{rrrrr}<0.5 & <0.5 & <0.5 & 534 & 60 \\ <0.5 & <0.5 & <0.5 & 85 & 15 \\ <0.5 & <0.5 & <0.5 & 216 & 20 \\ <0.5 & <0.5 & <0.5 & 115 & 14 \\ <0.5 & <0.5 & <0.5 & 293 & 63 \\ <0.5 & <0.5 & <0.5 & 81 & 38 \\ <0.5 & <0.5 & <0.5 & 576 & 100 \\ <0.5 & <0.5 & <0.5 & 528 & 84\end{array}$

$\begin{array}{lllll}<0.1 & <0.1 & <0.1 & 540 & 57\end{array}$

$\begin{array}{lll}<0.1 & 0.7 & 1.6\end{array}$

$--$

$<0.1$

$--$

$<0.1$

$-$

$<0.1$

26

4

$<0.1$

$<0.1$

$<0.1$

127

17

$<0.1$

$<0.1$

$<0.1$

362

74

63

$<0.1$

$<0.1$

637

32

$<0.1$

0.3

0.3
1.2

574

$\begin{array}{r}77 \\ \hline\end{array}$

$\begin{array}{lccrr}<2.5 & <2.5 & <2.5 & 474 & 50 \\ -- & -- & -- & 9 & 1 \\ -- & -- & -- & -- & -- \\ <2.5 & <2.5 & <2.5 & 59 & 11\end{array}$


Table 7. Descriptive statistics for selected constituents or properties, by hydrogeologic unit, 1980-98-Continued

[--, data not available; <, less than]

\begin{tabular}{|c|c|c|c|c|c|c|c|}
\hline \multirow{2}{*}{$\begin{array}{l}\text { Constituent or property and } \\
\text { hydrogeologic unit }^{1}\end{array}$} & \multicolumn{5}{|c|}{ Percentile value } & \multirow{2}{*}{$\begin{array}{c}\text { Number } \\
\text { of } \\
\text { obser- } \\
\text { vations }\end{array}$} & \multirow{2}{*}{$\begin{array}{c}\text { Percentage } \\
\text { of unit } \\
\text { represented } \\
\text { (see p. 22) }\end{array}$} \\
\hline & 10th & 25th & 50th & 75th & 90th & & \\
\hline \multicolumn{8}{|c|}{ PESTICIDES-Continued } \\
\hline Nebraska Sand Hills & $<2.5$ & $<2.5$ & $<2.5$ & $<2.5$ & $<2.5$ & 273 & 61 \\
\hline Kansas Quaternary Deposits & -- & -- & -- & -- & -- & 1 & 1 \\
\hline Nebraska Quaternary Deposits & $<2.5$ & $<2.5$ & $<2.5$ & $<2.5$ & $<2.5$ & 532 & 100 \\
\hline Valley-Fill Alluvium & $<2.5$ & $<2.5$ & $<2.5$ & $<2.5$ & $<2.5$ & 326 & 66 \\
\hline \multicolumn{8}{|l|}{ Carbofuran, in micrograms per liter } \\
\hline Ogallala Formation-North & $<1.0$ & $<1.0$ & $<1.0$ & $<1.0$ & $<1.0$ & 482 & 54 \\
\hline Ogallala Formation—Central & $<1.0$ & $<1.0$ & $<1.0$ & $<1.0$ & $<1.0$ & 59 & 14 \\
\hline Ogallala Formation—South & $<1.0$ & $<1.0$ & $<1.0$ & $<1.0$ & $<1.0$ & 171 & 8 \\
\hline Arikaree-Brule Formations & $<1.0$ & $<1.0$ & $<1.0$ & $<1.0$ & $<1.0$ & 60 & 11 \\
\hline Nebraska Sand Hills & $<1.0$ & $<1.0$ & $<1.0$ & $<1.0$ & $<1.0$ & 256 & 60 \\
\hline Kansas Quaternary Deposits & -- & -- & -- & -- & -- & 6 & 6 \\
\hline Nebraska Quaternary Deposits & $<1.0$ & $<1.0$ & $<1.0$ & $<1.0$ & $<1.0$ & 432 & 100 \\
\hline Valley-Fill Alluvium & $<1.0$ & $<1.0$ & $<1.0$ & $<1.0$ & $<1.0$ & 319 & 73 \\
\hline \multicolumn{8}{|l|}{ Cyanazine, in micrograms per liter } \\
\hline Ogallala Formation-North & $<1.0$ & $<1.0$ & $<1.0$ & $<1.0$ & $<1.0$ & 538 & 56 \\
\hline Ogallala Formation—Central & $<1.0$ & $<1.0$ & $<1.0$ & $<1.0$ & $<1.0$ & 18 & 2 \\
\hline Ogallala Formation—South & -- & -- & -- & -- & -- & 3 & 1 \\
\hline Arikaree-Brule Formations & $<1.0$ & $<1.0$ & $<1.0$ & $<1.0$ & $<1.0$ & 125 & 16 \\
\hline Nebraska Sand Hills & $<1.0$ & $<1.0$ & $<1.0$ & $<1.0$ & $<1.0$ & 330 & 63 \\
\hline Kansas Quaternary Deposits & $<1.0$ & $<1.0$ & $<1.0$ & $<1.0$ & $<1.0$ & 74 & 32 \\
\hline Nebraska Quaternary Deposits & $<1.0$ & $<1.0$ & $<1.0$ & $<1.0$ & $<1.0$ & 596 & 100 \\
\hline Valley-Fill Alluvium & $<1.0$ & $<1.0$ & $<1.0$ & $<1.0$ & $<1.0$ & 536 & 73 \\
\hline \multicolumn{8}{|l|}{ Chlorpyrifos, in micrograms per liter } \\
\hline Ogallala Formation—North & $<0.5$ & $<0.5$ & $<0.5$ & $<0.5$ & 0.9 & 462 & 43 \\
\hline Ogallala Formation-Central & -- & -- & -- & -- & -- & -- & -- \\
\hline Ogallala Formation—South & -- & -- & -- & -- & -- & -- & -- \\
\hline Arikaree-Brule Formations & $<0.5$ & $<0.5$ & 0.9 & 0.9 & 0.9 & 123 & 25 \\
\hline Nebraska Sand Hills & $<0.5$ & $<0.5$ & $<0.5$ & $<0.5$ & $<0.5$ & 276 & 66 \\
\hline Kansas Quaternary Deposits & -- & -- & -- & -- & -- & -- & -- \\
\hline Nebraska Quaternary Deposits & $<0.5$ & $<0.5$ & $<0.5$ & $<0.5$ & $<0.5$ & 595 & 100 \\
\hline Valley-Fill Alluvium & $<0.5$ & $<0.5$ & $<0.5$ & $<0.5$ & 0.9 & 368 & 71 \\
\hline \multicolumn{8}{|l|}{ Fonofos, in micrograms per liter } \\
\hline Ogallala Formation-North & $<0.2$ & $<0.2$ & $<0.2$ & $<0.2$ & 0.4 & 443 & 43 \\
\hline Ogallala Formation-Central & -- & -- & -- & -- & -- & -- & -- \\
\hline Ogallala Formation—South & -- & -- & -- & -- & -- & -- & -- \\
\hline Arikaree-Brule Formations & $<0.2$ & $<0.2$ & $<0.2$ & $<0.2$ & $<0.2$ & 124 & 25 \\
\hline Nebraska Sand Hills & $<0.2$ & $<0.2$ & $<0.2$ & $<0.2$ & $<0.2$ & 278 & 66 \\
\hline Kansas Quaternary Deposits & -- & -- & -- & -- & -- & -- & -- \\
\hline Nebraska Quaternary Deposits & $<0.2$ & $<0.2$ & $<0.2$ & $<0.2$ & $<0.2$ & 616 & 100 \\
\hline Valley-Fill Alluvium & $<0.2$ & $<0.2$ & $<0.2$ & $<0.2$ & $<0.2$ & 375 & 72 \\
\hline \multicolumn{8}{|l|}{ Metolachlor, in micrograms per liter } \\
\hline Ogallala Formation-North & $<0.2$ & $<0.2$ & $<0.2$ & $<0.2$ & $<0.2$ & 143 & 21 \\
\hline
\end{tabular}


Table 7. Descriptive statistics for selected constituents or properties, by hydrogeologic unit, 1980-98-Continued

[--, data not available; <, less than]

\begin{tabular}{|c|c|c|c|c|c|c|c|}
\hline \multirow{2}{*}{$\begin{array}{l}\text { Constituent or property and } \\
\text { hydrogeologic unit }^{1}\end{array}$} & \multicolumn{5}{|c|}{ Percentile value } & \multirow{2}{*}{$\begin{array}{c}\text { Number } \\
\text { of } \\
\text { obser- } \\
\text { vations }\end{array}$} & \multirow{2}{*}{$\begin{array}{l}\text { Percentage } \\
\text { of unit } \\
\text { represented } \\
\text { (see p. 22) }\end{array}$} \\
\hline & 10th & 25th & 50th & 75th & 90th & & \\
\hline \multicolumn{8}{|c|}{ PESTICIDES-Continued } \\
\hline Ogallala Formation—Central & $<0.2$ & $<0.2$ & $<0.2$ & $<0.2$ & 0.4 & 20 & 3 \\
\hline Ogallala Formation-South & $<0.2$ & $<0.2$ & $<0.2$ & $<0.2$ & $<0.2$ & 186 & 13 \\
\hline Arikaree-Brule Formations & $<0.2$ & $<0.2$ & $<0.2$ & $<0.2$ & $<0.2$ & 70 & 9 \\
\hline Nebraska Sand Hills & $<0.2$ & $<0.2$ & $<0.2$ & $<0.2$ & $<0.2$ & 26 & 6 \\
\hline Kansas Quaternary Deposits & $<0.2$ & $<0.2$ & $<0.2$ & $<0.2$ & $<0.2$ & 68 & 30 \\
\hline Nebraska Quaternary Deposits & $<0.2$ & $<0.2$ & $<0.2$ & $<0.2$ & $<0.2$ & 84 & 26 \\
\hline Valley-Fill Alluvium & $<0.2$ & $<0.2$ & $<0.2$ & $<0.2$ & $<0.2$ & 266 & 48 \\
\hline \multicolumn{8}{|l|}{ Terbufos, in micrograms per liter } \\
\hline Ogallala Formation—North & $<0.9$ & $<0.9$ & $<0.9$ & $<0.9$ & $<0.9$ & 462 & 43 \\
\hline Ogallala Formation—Central & --- & -- & -- & -- & -- & -- & -- \\
\hline Ogallala Formation—South & -- & -- & -- & -- & -- & -- & -- \\
\hline Arikaree-Brule Formations & $<0.9$ & $<0.9$ & $<0.9$ & $<0.9$ & $<0.9$ & 123 & 25 \\
\hline Nebraska Sand Hills & $<0.9$ & $<0.9$ & $<0.9$ & $<0.9$ & $<0.9$ & 276 & 66 \\
\hline Kansas Quaternary Deposits & -- & -- & -- & -- & -- & -- & -- \\
\hline Nebraska Quaternary Deposits & $<0.9$ & $<0.9$ & $<0.9$ & $<0.9$ & $<0.9$ & 595 & 100 \\
\hline Valley-Fill Alluvium & $<0.9$ & $<0.9$ & $<0.9$ & $<0.9$ & $<0.9$ & 368 & 71 \\
\hline \multicolumn{8}{|l|}{ Trifluralin, in micrograms per liter } \\
\hline Ogallala Formation—North & $<0.25$ & $<0.25$ & $<0.25$ & $<0.25$ & $<0.25$ & 374 & 38 \\
\hline Ogallala Formation-Central & -- & -- & -- & -- & -- & 9 & 1 \\
\hline Ogallala Formation-South & -- & -- & -- & -- & -- & 3 & 1 \\
\hline Arikaree-Brule Formations & $<0.25$ & $<0.25$ & $<0.25$ & $<0.25$ & $<0.25$ & 61 & 11 \\
\hline Nebraska Sand Hills & $<0.25$ & $<0.25$ & $<0.25$ & $<0.25$ & $<0.25$ & 285 & 63 \\
\hline Kansas Quaternary Deposits & $<0.25$ & $<0.25$ & $<0.25$ & $<0.25$ & $<0.25$ & 68 & 30 \\
\hline Nebraska Quaternary Deposits & $<0.25$ & $<0.25$ & $<0.25$ & $<0.25$ & $<0.25$ & 571 & 100 \\
\hline Valley-Fill Alluvium & $<0.25$ & $<0.25$ & $<0.25$ & $<0.25$ & $<0.25$ & 384 & 67 \\
\hline
\end{tabular}

Calcium, in milligrams per liter as Ca

MAJOR IONS

Ogallala Formation-North

33.0

41.7

52.0

78.3

$97.1 \quad 530$

64

Ogallala Formation-Central

14.1

16.4

19.6

26.4

55.7

1,217

58

Ogallala Formation-South

13.6

24.4

42.4

71.9

2,181

80

Arikaree-Brule Formations

38.0

50.0

75.0

110.0

351

33

13.1

35.0

63.8

77.7

202

37

Kansas Quaternary Deposits

49.0

69.0

100.0

149.0

211

62

55.1

69.0

80.4

Valley-Fill Alluvium

54.0

74.2

97.0

96.0

120.0

431

87

Magnesium, in milligrams per liter as Mg

Ogallala Formation-North

7.0

10.0

12.6

125.0

169.0

850

82

Ogallala Formation-Central

1.5

2.5

16.8

23.0

$530 \quad 64$

Ogallala Formation-South

2.8

3.7

3.8

12.0

1,217

58

Arikaree-Brule Formations

1.8

5.3

5.5

10.6

19.2

2,181

80

Nebraska Sand Hills

$\begin{array}{ll}2.0 & 3.0\end{array}$

8.8

16.0

26.8

351

33

Kansas Quaternary Deposits

3.7

5.0

5.1

9.5

11.6

202

37

8.5

10.4

12.1

13.0
15.0

24.7

211

62

19.2

430

87 
Table 7. Descriptive statistics for selected constituents or properties, by hydrogeologic unit, 1980-98—Continued

[--, data not available; <, less than]

\begin{tabular}{|c|c|c|c|c|c|c|c|}
\hline \multirow{2}{*}{$\begin{array}{l}\text { Constituent or property and } \\
\text { hydrogeologic unit }^{1}\end{array}$} & \multicolumn{5}{|c|}{ Percentile value } & \multirow{2}{*}{$\begin{array}{c}\text { Number } \\
\text { of } \\
\text { obser- } \\
\text { vations }\end{array}$} & \multirow{2}{*}{$\begin{array}{c}\text { Percentage } \\
\text { of unit } \\
\text { represented } \\
\text { (see p. 22) }\end{array}$} \\
\hline & 10th & 25th & 50th & 75th & 90th & & \\
\hline \multicolumn{8}{|c|}{ MAJOR IONS-Continued } \\
\hline Valley-Fill Alluvium & 10.0 & 14.0 & 20.0 & 28.0 & 40.0 & 850 & 82 \\
\hline \multicolumn{8}{|l|}{ Sodium, in milligrams per liter as $\mathrm{Na}$} \\
\hline Ogallala Formation—North & 7.3 & 9.2 & 13.0 & 20.1 & 32.9 & 530 & 64 \\
\hline Ogallala Formation-Central & 14.0 & 19.6 & 26.0 & 39.0 & 62.0 & 1,222 & 61 \\
\hline Ogallala Formation—South & 28.7 & 38.0 & 61.0 & 120.0 & 266.0 & 2,210 & 80 \\
\hline Arikaree-Brule Formations & 5.1 & 12.0 & 41.0 & 67.0 & 110.0 & 351 & 33 \\
\hline Nebraska Sand Hills & 5.0 & 5.9 & 7.6 & 10.4 & 13.1 & 202 & 37 \\
\hline Kansas Quaternary Deposits & 10.0 & 16.0 & 27.0 & 46.8 & 76.5 & 212 & 62 \\
\hline Nebraska Quaternary Deposits & 12.0 & 16.9 & 24.0 & 37.0 & 52.0 & 430 & 87 \\
\hline Valley-Fill Alluvium & 25.1 & 42.0 & 84.0 & 156.0 & 400.0 & 850 & 82 \\
\hline \multicolumn{8}{|l|}{ Potassium, in milligrams per liter as K } \\
\hline Ogallala Formation—-North & 3.4 & 4.7 & 6.3 & 9.1 & 12.0 & 520 & 63 \\
\hline Ogallala Formation—Central & 2.8 & 4.0 & 5.0 & 6.0 & 6.9 & 978 & 58 \\
\hline Ogallala Formation—South & 4.5 & 6.0 & 8.4 & 14.0 & 21.0 & 1,964 & 80 \\
\hline Arikaree-Brule Formations & 5.0 & 6.5 & 8.8 & 12.0 & 16.0 & 281 & 33 \\
\hline Nebraska Sand Hills & 3.6 & 4.2 & 4.9 & 5.8 & 7.0 & 190 & 36 \\
\hline Kansas Quaternary Deposits & 1.4 & 2.0 & 2.7 & 3.3 & 5.0 & 206 & 61 \\
\hline Nebraska Quaternary Deposits & 4.2 & 5.0 & 6.6 & 8.8 & 11.6 & 430 & 87 \\
\hline Valley-Fill Alluvium & 2.6 & 3.4 & 5.6 & 11.0 & 18.0 & 823 & 80 \\
\hline \multicolumn{8}{|l|}{ Silica, in milligrams per liter as $\mathrm{SiO}_{2}$} \\
\hline Ogallala Formation—-North & 37.8 & 48.0 & 55.0 & 60.0 & 65.0 & 267 & 45 \\
\hline Ogallala Formation-Central & 23.6 & 27.0 & 30.0 & 36.0 & 47.0 & 1,041 & 56 \\
\hline Ogallala Formation—South & 29.0 & 39.0 & 49.0 & 58.0 & 65.0 & 1,902 & 74 \\
\hline Arikaree-Brule Formations & 36.3 & 51.0 & 58.0 & 64.0 & 68.0 & 202 & 28 \\
\hline Nebraska Sand Hills & 30.0 & 38.0 & 47.0 & 52.0 & 58.0 & 93 & 30 \\
\hline Kansas Quaternary Deposits & 17.6 & 21.0 & 23.0 & 28.7 & 36.3 & 194 & 59 \\
\hline Nebraska Quaternary Deposits & 27.0 & 30.5 & 35.0 & 44.0 & 49.6 & 133 & 69 \\
\hline Valley-Fill Alluvium & 17.0 & 19.7 & 24.0 & 33.5 & 52.0 & 677 & 71 \\
\hline \multicolumn{8}{|c|}{ Alkalinity, in milligrams per liter as $\mathrm{CaCO}_{3}$} \\
\hline Ogallala Formation-North & 103 & 122 & 151 & 222 & 280 & 457 & 62 \\
\hline Ogallala Formation-Central & 164 & 185 & 200 & 217 & 238 & 1,331 & 63 \\
\hline Ogallala Formation—South & 178 & 205 & 239 & 274 & 310 & 2,147 & 80 \\
\hline Arikaree-Brule Formations & 138 & 157 & 180 & 220 & 301 & 238 & 33 \\
\hline Nebraska Sand Hills & 41 & 49 & 65 & 81 & 106 & 123 & 32 \\
\hline Kansas Quaternary Deposits & 83 & 129 & 180 & 233 & 290 & 214 & 62 \\
\hline Nebraska Quaternary Deposits & 154 & 192 & 222 & 260 & 308 & 133 & 69 \\
\hline Valley-Fill Alluvium & 150 & 186 & 227 & 270 & 322 & 727 & 72 \\
\hline \multicolumn{8}{|l|}{ Sulfate, in milligrams per liter as $\mathrm{SO}_{4}$} \\
\hline Ogallala Formation—-North & 5.5 & 12.9 & 27.2 & 55.8 & 95.7 & 530 & 64 \\
\hline Ogallala Formation-Central & 13.4 & 22.0 & 37.0 & 59.5 & 99.6 & 1,353 & 64 \\
\hline Ogallala Formation—South & 25.8 & 36.2 & 89.0 & 226.0 & 464.0 & 2,134 & 80 \\
\hline Arikaree-Brule Formations & 3.0 & 10.0 & 28.0 & 150.0 & 230.0 & 343 & 33 \\
\hline
\end{tabular}


Table 7. Descriptive statistics for selected constituents or properties, by hydrogeologic unit, 1980-98-Continued

[--, data not available; <, less than]

\begin{tabular}{|c|c|c|c|c|c|c|c|}
\hline \multirow{2}{*}{$\begin{array}{l}\text { Constituent or property and } \\
\text { hydrogeologic unit }^{1}\end{array}$} & \multicolumn{5}{|c|}{ Percentile value } & \multirow{2}{*}{$\begin{array}{c}\text { Number } \\
\text { of } \\
\text { obser- } \\
\text { vations }\end{array}$} & \multirow{2}{*}{$\begin{array}{c}\text { Percentage } \\
\text { of unit } \\
\text { represented } \\
\text { (see p. 22) }\end{array}$} \\
\hline & 10th & 25th & 50th & 75th & 90th & & \\
\hline \multicolumn{8}{|c|}{ MAJOR IONS-Continued } \\
\hline Nebraska Sand Hills & 2.4 & 3.9 & 7.6 & 13.1 & 19.6 & 182 & 36 \\
\hline Kansas Quaternary Deposits & 9.0 & 12.0 & 21.0 & 36.0 & 78.5 & 214 & 63 \\
\hline Nebraska Quaternary Deposits & 16.0 & 24.8 & 37.5 & 67.6 & 122.0 & 431 & 87 \\
\hline Valley-Fill Alluvium & 23.0 & 49.0 & 93.0 & 185.0 & 300.0 & 850 & 82 \\
\hline \multicolumn{8}{|l|}{ Chloride, in milligrams per liter as $\mathrm{Cl}$} \\
\hline Ogallala Formation-North & 1.4 & 2.4 & 4.5 & 11.8 & 29.5 & 530 & 64 \\
\hline Ogallala Formation-Central & 7.0 & 9.1 & 15.0 & 30.0 & 83.0 & 1,390 & 63 \\
\hline Ogallala Formation-South & 12.0 & 21.0 & 66.0 & 193.0 & 464.0 & 2,244 & 80 \\
\hline Arikaree-Brule Formations & 1.7 & 3.8 & 6.6 & 14.0 & 20.0 & 356 & 33 \\
\hline Nebraska Sand Hills & 0.7 & 0.9 & 1.3 & 4.1 & 9.9 & 193 & 36 \\
\hline Kansas Quaternary Deposits & 3.2 & 6.1 & 18.0 & 71.0 & 297.0 & 270 & 63 \\
\hline Nebraska Quaternary Deposits & 2.6 & 5.5 & 11.6 & 20.8 & 35.2 & 431 & 87 \\
\hline Valley-Fill Alluvium & 12.0 & 22.0 & 50.0 & 200.0 & 632.0 & 851 & 83 \\
\hline \multicolumn{8}{|l|}{ Fluoride, in milligrams per liter as F } \\
\hline Ogallala Formation—North & 0.2 & 0.3 & 0.4 & 0.7 & 1.2 & 266 & 45 \\
\hline Ogallala Formation—Central & 0.4 & 0.8 & 1.2 & 1.7 & 2.1 & 1,299 & 58 \\
\hline Ogallala Formation—South & 1.3 & 1.9 & 2.7 & 3.9 & 5.0 & 2,064 & 78 \\
\hline Arikaree-Brule Formations & 0.2 & 0.3 & 0.4 & 0.6 & 1.0 & 218 & 30 \\
\hline Nebraska Sand Hills & 0.1 & 0.2 & 0.3 & 0.3 & 0.4 & 93 & 30 \\
\hline Kansas Quaternary Deposits & 0.2 & 0.2 & 0.3 & 0.4 & 0.5 & 200 & 61 \\
\hline Nebraska Quaternary Deposits & 0.2 & 0.2 & 0.3 & 0.3 & 0.4 & 133 & 69 \\
\hline Valley-Fill Alluvium & 0.2 & 0.3 & 0.4 & 0.6 & 0.7 & 712 & 71 \\
\hline \multicolumn{8}{|l|}{ Dissolved solids, in milligrams per liter } \\
\hline Ogallala Formation-North & 219 & 275 & 315 & 371 & 461 & 457 & 62 \\
\hline Ogallala Formation—Central & 254 & 281 & 320 & 379 & 538 & 1,264 & 63 \\
\hline Ogallala Formation—South & 329 & 384 & 517 & 896 & 1,620 & 2,077 & 80 \\
\hline Arikaree-Brule Formations & 206 & 239 & 295 & 412 & 561 & 277 & 33 \\
\hline Nebraska Sand Hills & 118 & 130 & 155 & 247 & 317 & 112 & 32 \\
\hline Kansas Quaternary Deposits & 173 & 211 & 290 & 468 & 701 & 222 & 62 \\
\hline Nebraska Quaternary Deposits & 260 & 330 & 382 & 467 & 572 & 132 & 69 \\
\hline Valley-Fill Alluvium & 314 & 412 & 603 & 862 & 1,350 & 469 & 72 \\
\hline
\end{tabular}

Dissolved arsenic, in micrograms per liter

Ogallala Formation-North $\quad<5$

Ogallala Formation-Central $<5$

Ogallala Formation-South $\quad<5$

Arikaree-Brule Formations

Nebraska Sand Hills

Kansas Quaternary Deposits

Nebraska Quaternary Deposits

Valley-Fill Alluvium

Dissolved boron, in micrograms per liter

Ogallala Formation-North
$<5$

$<5$

$<5$

$<5$

$<5$

$--$

$<5$

20

\section{TRACE ELEMENTS}

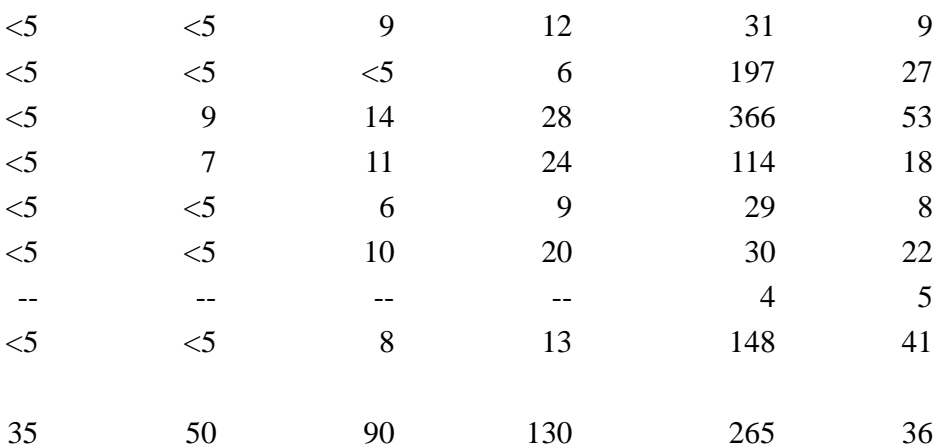


Table 7. Descriptive statistics for selected constituents or properties, by hydrogeologic unit, 1980-98-Continued

[--, data not available; <, less than]

\begin{tabular}{|c|c|c|c|c|c|c|c|}
\hline \multirow{2}{*}{$\begin{array}{l}\text { Constituent or property and } \\
\text { hydrogeologic unit }^{1}\end{array}$} & \multicolumn{5}{|c|}{ Percentile value } & \multirow{2}{*}{$\begin{array}{c}\text { Number } \\
\text { of } \\
\text { obser- } \\
\text { vations }\end{array}$} & \multirow{2}{*}{$\begin{array}{c}\text { Percentage } \\
\text { of unit } \\
\text { represented } \\
\text { (see p. 22) }\end{array}$} \\
\hline & 10th & 25th & 50th & 75th & 90th & & \\
\hline \multicolumn{8}{|c|}{ TRACE ELEMENTS-Continued } \\
\hline Ogallala Formation—Central & 63 & 97 & 134 & 200 & 267 & 302 & 26 \\
\hline Ogallala Formation—South & 134 & 197 & 318 & 500 & 900 & 586 & 57 \\
\hline Arikaree-Brule Formations & 20 & 40 & 70 & 110 & 230 & 130 & 22 \\
\hline Nebraska Sand Hills & 20 & 20 & 30 & 130 & 131 & 28 & 14 \\
\hline Kansas Quaternary Deposits & -- & -- & -- & -- & -- & 7 & 1 \\
\hline Nebraska Quaternary Deposits & 30 & 40 & 50 & 80 & 121 & 98 & 61 \\
\hline Valley-Fill Alluvium & 52 & 70 & 93 & 120 & 184 & 202 & 27 \\
\hline \multicolumn{8}{|l|}{ Dissolved copper, in micrograms per liter } \\
\hline Ogallala Formation-North & $<5$ & $<5$ & 6 & 10 & 35 & 18 & 6 \\
\hline Ogallala Formation-Central & $<5$ & $<5$ & $<5$ & $<5$ & 9 & 189 & 24 \\
\hline Ogallala Formation-South & $<5$ & $<5$ & $<5$ & $<5$ & 8 & 315 & 52 \\
\hline Arikaree-Brule Formations & $<5$ & $<5$ & $<5$ & $<5$ & 9 & 26 & 4 \\
\hline Nebraska Sand Hills & $<5$ & $<5$ & $<5$ & $<5$ & $<5$ & 27 & 7 \\
\hline Kansas Quaternary Deposits & $<5$ & 7 & 10 & 20 & 28 & 30 & 20 \\
\hline Nebraska Quaternary Deposits & -- & -- & -- & -- & -- & 2 & 2 \\
\hline Valley-Fill Alluvium & $<5$ & $<5$ & 8 & 11 & 18 & 218 & 36 \\
\hline \multicolumn{8}{|l|}{ Dissolved iron, in micrograms per liter } \\
\hline Ogallala Formation—North & $<3$ & $<3$ & 5 & 20 & 60 & 115 & 25 \\
\hline Ogallala Formation-Central & 7 & 11 & 22 & 35 & 54 & 184 & 27 \\
\hline Ogallala Formation-South & 6 & 10 & 21 & 37 & 62 & 280 & 48 \\
\hline Arikaree-Brule Formations & $<3$ & $<3$ & $<3$ & 5 & 15 & 127 & 19 \\
\hline Nebraska Sand Hills & $<3$ & 4 & 9 & 30 & 67 & 39 & 13 \\
\hline Kansas Quaternary Deposits & $<3$ & $<3$ & 10 & 30 & 144 & 122 & 53 \\
\hline Nebraska Quaternary Deposits & $<3$ & $<3$ & 10 & 47 & 604 & 92 & 57 \\
\hline Valley-Fill Alluvium & $<3$ & 4 & 40 & 545 & 2,200 & 384 & 58 \\
\hline \multicolumn{8}{|l|}{ Dissolved lead, in micrograms per liter } \\
\hline Ogallala Formation—-North & $<5$ & $<5$ & $<5$ & $<5$ & $<5$ & 22 & 7 \\
\hline Ogallala Formation-Central & $<5$ & $<5$ & $<5$ & $<5$ & $<5$ & 197 & 27 \\
\hline Ogallala Formation-South & $<5$ & $<5$ & $<5$ & $<5$ & $<5$ & 309 & 52 \\
\hline Arikaree-Brule Formations & $<5$ & $<5$ & $<5$ & $<5$ & 10 & 35 & 5 \\
\hline Nebraska Sand Hills & $<5$ & $<5$ & $<5$ & $<5$ & $<5$ & 27 & 7 \\
\hline Kansas Quaternary Deposits & $<5$ & $<5$ & $<5$ & $<5$ & 10 & 24 & 19 \\
\hline Nebraska Quaternary Deposits & -- & -- & -- & -- & -- & 2 & 2 \\
\hline Valley-Fill Alluvium & $<5$ & $<5$ & $<5$ & $<5$ & $<5$ & 112 & 34 \\
\hline \multicolumn{8}{|l|}{ Dissolved lithium, in micrograms per liter } \\
\hline Ogallala Formation-North & -- & -- & -- & -- & -- & 6 & 2 \\
\hline Ogallala Formation-Central & 13 & 31 & 44 & 66 & 85 & 176 & 21 \\
\hline Ogallala Formation—South & 39 & 53 & 75 & 114 & 155 & 308 & 52 \\
\hline Arikaree-Brule Formations & 15 & 21 & 31 & 44 & 51 & 59 & 11 \\
\hline Nebraska Sand Hills & -- & -- & -- & -- & -- & 1 & 1 \\
\hline Kansas Quaternary Deposits & -- & -- & -- & -- & -- & -- & -- \\
\hline Nebraska Quaternary Deposits & -- & -- & -- & -- & -- & -- & -- \\
\hline Valley-Fill Alluvium & 16 & 20 & 33 & 48 & 73 & 15 & 9 \\
\hline
\end{tabular}


Table 7. Descriptive statistics for selected constituents or properties, by hydrogeologic unit, 1980-98-Continued

[--, data not available; <, less than]

\begin{tabular}{|c|c|c|c|c|c|c|c|}
\hline \multirow{2}{*}{$\begin{array}{l}\text { Constituent or property and } \\
\text { hydrogeologic unit }^{1}\end{array}$} & \multicolumn{5}{|c|}{ Percentile value } & \multirow{2}{*}{$\begin{array}{c}\text { Number } \\
\text { of } \\
\text { obser- } \\
\text { vations }\end{array}$} & \multirow{2}{*}{$\begin{array}{l}\text { Percentage } \\
\text { of unit } \\
\text { represented } \\
\text { (see p. 22) }\end{array}$} \\
\hline & 10th & 25th & 50th & 75th & 90th & & \\
\hline
\end{tabular}

TRACE ELEMENTS-Continued

Dissolved manganese, in micrograms per liter

Ogallala Formation-North $\quad<3$

Ogallala Formation-Central

Ogallala Formation-South

Arikaree-Brule Formations

Nebraska Sand Hills

Kansas Quaternary Deposits

Nebraska Quaternary Deposits

Valley-Fill Alluvium

Dissolved selenium, in micrograms per liter

Ogallala Formation-North

Ogallala Formation-Central

Ogallala Formation-South

Arikaree-Brule Formations

Nebraska Sand Hills

Kansas Quaternary Deposits

Nebraska Quaternary Deposits

Valley-Fill Alluvium

Dissolved zinc, in micrograms per liter

Ogallala Formation-North

Ogallala Formation-Central

Ogallala Formation-South

Arikaree-Brule Formations

Nebraska Sand Hills

Kansas Quaternary Deposits

Nebraska Quaternary Deposits

Valley-Fill Alluvium

Radium, in picocuries per liter

Ogallala Formation-North

Ogallala Formation-Central

Ogallala Formation-South

Arikaree-Brule Formations

Nebraska Sand Hills

Kansas Quaternary Deposits

Nebraska Quaternary Deposits

Valley-Fill Alluvium

Radon, in picocuries per liter

Ogallala Formation-North

Ogallala Formation-Central

Ogallala Formation-South

Arikaree-Brule Formations

\section{$-$}

$-$

0.05

0.06

$-$

$--$

$--$

0.15

$-$

108

257

$<3$
$<3$
$<3$
$<3$
$<3$
$<3$
$<3$
40

10
$<3$
$<3$
$<3$
$<3$
10
62
243

$\begin{array}{rrr}40 & 134 & 28 \\ 10 & 223 & 30 \\ 26 & 325 & 52 \\ 9 & 129 & 19 \\ 45 & 44 & 15 \\ 313 & 118 & 52 \\ 402 & 117 & 66 \\ 681 & 388 & 60\end{array}$

$<5$

$\begin{array}{rr}35 & 11 \\ 336 & 30 \\ 530 & 55 \\ 126 & 21 \\ 29 & 8 \\ 25 & 20 \\ 4 & 5 \\ 122 & 40\end{array}$

124

$26 \quad 8$

$239 \quad 26$

$361 \quad 53$

134

38

42

140

$-$

233

$\begin{array}{rr}85 & 14 \\ 29 & 8 \\ 32 & 23 \\ 2 & 2 \\ 238 & 41\end{array}$

\section{RADIOLOGICAL PARAMETERS}

$\begin{array}{rllllrr}- & -- & -- & -- & -- & 6 & 2 \\ - & -- & -- & -- & -- & 2 & 1 \\ 0.05 & 0.08 & 0.20 & 0.40 & 1.06 & 181 & 38 \\ 0.06 & 0.10 & 0.13 & 0.19 & 0.22 & 25 & 8 \\ - & -- & -- & -- & -- & -- & -- \\ - & -- & -- & -- & -- & -- & -- \\ - & -- & -- & -- & -- & -- & -- \\ 0.15 & 0.19 & 0.32 & 0.38 & 0.45 & 31 & 8 \\ & & -- & -- & -- & & \\ - & -- & -- & -- & -- & -- & -- \\ - & -- & - & & & 92 & 16 \\ 08 & 155 & 220 & 390 & 838 & 124 & 10\end{array}$


Table 7. Descriptive statistics for selected constituents or properties, by hydrogeologic unit, 1980-98-Continued

[--, data not available; <, less than]

\begin{tabular}{|c|c|c|c|c|c|c|c|}
\hline \multirow{2}{*}{$\begin{array}{l}\text { Constituent or property and } \\
\text { hydrogeologic unit }^{1}\end{array}$} & \multicolumn{5}{|c|}{ Percentile value } & \multirow{2}{*}{$\begin{array}{l}\text { Number } \\
\text { of } \\
\text { obser- } \\
\text { vations }\end{array}$} & \multirow{2}{*}{$\begin{array}{c}\text { Percentage } \\
\text { of unit } \\
\text { represented } \\
\text { (see p. 22) }\end{array}$} \\
\hline & 10th & 25th & 50th & 75th & 90th & & \\
\hline \multicolumn{8}{|c|}{ RADIOLOGICAL PARAMETERS-Continued } \\
\hline Nebraska Sand Hills & -- & -- & -- & -- & -- & -- & -- \\
\hline Kansas Quaternary Deposits & -- & -- & -- & -- & -- & -- & -- \\
\hline Nebraska Quaternary Deposits & -- & -- & -- & -- & -- & 2 & 2 \\
\hline Valley-Fill Alluvium & 225 & 292 & 403 & 542 & 606 & 57 & 27 \\
\hline \multicolumn{8}{|l|}{ Uranium, in micrograms per liter } \\
\hline Ogallala Formation—North & -- & -- & -- & -- & -- & 9 & 3 \\
\hline Ogallala Formation—Central & -- & -- & -- & -- & -- & -- & -- \\
\hline Ogallala Formation—South & -- & -- & -- & -- & -- & -- & -- \\
\hline Arikaree-Brule Formations & 3.9 & 6.8 & 12.0 & 18.0 & 25.6 & 77 & 13 \\
\hline Nebraska Sand Hills & -- & -- & -- & -- & -- & 1 & 1 \\
\hline Kansas Quaternary Deposits & -- & -- & -- & -- & -- & -- & -- \\
\hline Nebraska Quaternary Deposits & -- & -- & -- & -- & -- & 2 & 2 \\
\hline Valley-Fill Alluvium & 4.3 & 8.6 & 20.0 & 26.0 & 43.0 & 51 & 22 \\
\hline
\end{tabular}

Benzene, in micrograms per liter

Ogallala Formation-North

Ogallala Formation-Central

Ogallala Formation-South

Arikaree-Brule Formations

Nebraska Sand Hills

Kansas Quaternary Deposits

Nebraska Quaternary Deposits

Valley-Fill Alluvium

\section{VOLATILE ORGANIC COMPOUNDS ${ }^{2}$}

$\begin{array}{rrrrrrr}<0.5 & <0.5 & <0.5 & <0.5 & <0.5 & 33 & 7 \\ <0.5 & <0.5 & <0.5 & <0.5 & <0.5 & 62 & 12 \\ -- & -- & -- & -- & -- & -- & -- \\ -- & -- & -- & -- & -- & 6 & 2 \\ -- & -- & -- & -- & -- & 1 & 1 \\ <0.5 & <0.5 & <0.5 & <0.5 & <0.5 & 13 & 13 \\ <0.5 & <0.5 & <0.5 & <0.5 & <0.5 & 14 & 16 \\ <0.5 & <0.5 & <0.5 & <0.5 & <0.5 & 105 & 41\end{array}$

Carbon tetrachloride, in micrograms per liter

Ogallala Formation-North
Ogallala Formation-Central
Ogallala Formation-South
Arikaree-Brule Formations
Nebraska Sand Hills
Kansas Quaternary Deposits
Nebraska Quaternary Deposits
Valley-Fill Alluvium

$\begin{array}{llll}<0.7 & <0.7 & <0.7 \\ <0.7 & <0.7 & <0.7 & <0 . \\ -- & -- & -- & -- \\ -- & -- & -- & <0 . \\ -- & -- & <0.7 & <0 . \\ <0.7 & <0.7 & <0.7 & <0 . \\ <0.7 & <0.7 & <0.7 & <0 . \\ <0.7 & <0.7 & -\end{array}$

$<0.7$

$<0.7$

39

$<0.7$

$<0.7$

$$
--
$$$$
-
$$

$-$

$<0.7$

$<0.7$

$<0.7$

$$
\text { -- }
$$

$<0.7$

$<0.7$

$<0.7$

$<0.7$

$<0.7$

$<0.7$

--

Ogallala Formation-Central

Arikaree-Brule Formations

Nebraska Sand Hills

Kansas Quaternary Deposits

Nebraska Quaternary Deposits

Valley-Fill Alluvium

$\begin{array}{lll}<0.7 & <0.7 & <0.7 \\ <0.7 & <0.7 & <0.7 \\ -- & -- & - \\ -- & -- & - \\ -- & -- & - \\ <0.7 & <0.7 & <0.7 \\ <0.7 & <0.7 & <0.7 \\ <0.7 & <0.7 & <0.7\end{array}$

$<0.7$
$<0.7$
--
--
--
$<0.7$
$<0.7$
$<0.7$

$-$

$-$

$<0.7$

$<0.7$

$<0.7$

$$
--
$$$$
-
$$$$
--
$$

$<0.7$

$<0.7$

$<0.7$

7
12
--
2
1
13
16
41 
Table 7. Descriptive statistics for selected constituents or properties, by hydrogeologic unit, 1980-98-Continued

[--, data not available; <, less than]

\begin{tabular}{|c|c|c|c|c|c|c|c|}
\hline \multirow{2}{*}{$\begin{array}{l}\text { Constituent or property and } \\
\text { hydrogeologic unit }^{1}\end{array}$} & \multicolumn{5}{|c|}{ Percentile value } & \multirow{2}{*}{$\begin{array}{c}\text { Number } \\
\text { of } \\
\text { obser- } \\
\text { vations }\end{array}$} & \multirow{2}{*}{$\begin{array}{l}\text { Percentage } \\
\text { of unit } \\
\text { represented } \\
\text { (see p. 22) }\end{array}$} \\
\hline & 10th & 25th & 50th & 75th & 90th & & \\
\hline \multicolumn{8}{|c|}{ VOLATILE ORGANIC COMPOUNDS-Continued } \\
\hline \multicolumn{8}{|c|}{ Methyl tert-butyl ether (MTBE), in micrograms per liter } \\
\hline Ogallala Formation-North & -- & -- & -- & -- & -- & 3 & 1 \\
\hline Ogallala Formation-Central & -- & -- & -- & -- & -- & -- & -- \\
\hline Ogallala Formation—South & -- & -- & -- & -- & -- & -- & -- \\
\hline Arikaree-Brule Formations & -- & -- & -- & -- & -- & 6 & 2 \\
\hline Nebraska Sand Hills & -- & -- & -- & -- & -- & -- & -- \\
\hline Kansas alluvial aquifer & -- & -- & -- & -- & -- & -- & -- \\
\hline Nebraska Quaternary Deposits & -- & -- & -- & -- & -- & 2 & 2 \\
\hline Valley-Fill Alluvium & $<0.2$ & $<0.2$ & $<0.2$ & $<0.2$ & $<0.2$ & 61 & 25 \\
\hline \multicolumn{8}{|l|}{ Vinyl chloride, in micrograms per liter } \\
\hline Ogallala Formation-North & $<0.8$ & $<0.8$ & $<0.8$ & $<0.8$ & $<0.8$ & 33 & 7 \\
\hline Ogallala Formation—Central & $<0.8$ & $<0.8$ & $<0.8$ & $<0.8$ & $<0.8$ & 62 & 12 \\
\hline Ogallala Formation—South & -- & -- & -- & -- & -- & -- & -- \\
\hline Arikaree-Brule Formations & -- & -- & -- & -- & -- & 6 & 2 \\
\hline Nebraska Sand Hills & -- & -- & -- & -- & -- & 1 & 1 \\
\hline Kansas Quaternary Deposits & $<0.8$ & $<0.8$ & $<0.8$ & $<0.8$ & $<0.8$ & 13 & 13 \\
\hline Nebraska Quaternary Deposits & $<0.8$ & $<0.8$ & $<0.8$ & $<0.8$ & $<0.8$ & 14 & 16 \\
\hline Valley-Fill Alluvium & $<0.8$ & $<0.8$ & $<0.8$ & $<0.8$ & $<0.8$ & 105 & 41 \\
\hline
\end{tabular}

${ }^{1}$ Except for trace elements, data summarized include both filtered and unfiltered sample observations. In general, filtered and unfiltered samples should yield similar results for most constituents in ground water. For trace elements, only filtered samples are included and results are for the dissolved phase, because substantial concentrations of trace elements can occur in both the dissolved and the suspended phases.

${ }^{2}$ Data from finished drinking-water data sets not included in volatile organic compound summary. 
Table 8. Selected constituents from the retrospective data base compared to drinking-water standards

[MCL, maximum contaminant level; SS, secondary standard; PMCL, proposed maximum contaminant level; ns, no standard; na, not applicable; --, insufficient data; mg/L, milligrams per liter; $\mu \mathrm{g} / \mathrm{L}$, micrograms per liter; $\mathrm{pCi} / \mathrm{L}$, picocuries per liter; \%, percent; <, less than]

\begin{tabular}{|c|c|c|c|c|c|c|c|}
\hline \multirow[b]{2}{*}{ Constituent $^{1}$} & \multicolumn{2}{|c|}{$\begin{array}{l}\text { Drinking-water } \\
\text { standard }^{2}\end{array}$} & \multirow[b]{2}{*}{$\begin{array}{c}\text { Number of } \\
\text { observations }\end{array}$} & \multicolumn{2}{|c|}{ Exceedances } & \multicolumn{2}{|c|}{ Detections } \\
\hline & $\begin{array}{c}\text { Numerical } \\
\text { standard }\end{array}$ & $\begin{array}{l}\text { Stan- } \\
\text { dard } \\
\text { type }\end{array}$ & & $\begin{array}{l}\text { Number of } \\
\text { exceedances }\end{array}$ & $\begin{array}{c}\text { Percentage of } \\
\text { total } \\
\text { observations }\end{array}$ & $\begin{array}{c}\text { Number } \\
\text { of } \\
\text { detections }\end{array}$ & $\begin{array}{c}\text { Percentage of } \\
\text { total } \\
\text { observations }\end{array}$ \\
\hline \multicolumn{8}{|c|}{ NUTRIENTS } \\
\hline Nitrate & $10 \mathrm{mg} / \mathrm{L}$ & MCL & 37,256 & 5,812 & 16 & 35,444 & 95 \\
\hline Nitrite & $1 \mathrm{mg} / \mathrm{L}$ & MCL & 2,826 & 0 & 0 & 701 & 25 \\
\hline \multicolumn{8}{|c|}{ PESTICIDES } \\
\hline 2,4-D & $70 \mu \mathrm{g} / \mathrm{L}$ & MCL & 1,477 & 0 & 0 & 8 & 0.5 \\
\hline Alachlor & $2 \mu \mathrm{g} / \mathrm{L}$ & MCL & 3,872 & 3 & 0.1 & 50 & 1.3 \\
\hline Atrazine & $3 \mu \mathrm{g} / \mathrm{L}$ & MCL & 4,387 & 62 & 1.4 & 1,090 & 25 \\
\hline Chlorpyrifos & $20 \mu \mathrm{g} / \mathrm{L}$ & SS & 2,323 & 0 & 0 & 6 & 0.3 \\
\hline Cyanazine & $1 \mu \mathrm{g} / \mathrm{L}$ & SS & 3,228 & 2 & 0.1 & 47 & 1.5 \\
\hline Diazinon & $0.6 \mu \mathrm{g} / \mathrm{L}$ & SS & 546 & 0 & 0 & 4 & 0.7 \\
\hline Metolachlor & $70 \mu \mathrm{g} / \mathrm{L}$ & SS & 3,380 & 0 & 0 & 146 & 4.3 \\
\hline Prometon & $100 \mu \mathrm{g} / \mathrm{L}$ & SS & 1,362 & 0 & 0 & 111 & 8.1 \\
\hline Simazine & $4 \mu \mathrm{g} / \mathrm{L}$ & MCL & 2,082 & 1 & 0 & 85 & 4.1 \\
\hline Trifluralin & $5 \mu \mathrm{g} / \mathrm{L}$ & SS & 2,481 & 0 & 0 & 20 & 0.8 \\
\hline \multicolumn{8}{|c|}{ MAJOR IONS } \\
\hline Chloride & $250 \mathrm{mg} / \mathrm{L}$ & SS & 26,889 & 2,256 & 8 & 24,689 & 92 \\
\hline Fluoride & $2 \mathrm{mg} / \mathrm{L}$ & SS & 14,611 & 1,885 & 13 & 14,504 & 99 \\
\hline Sulfate & $250 \mathrm{mg} / \mathrm{L}$ & SS & 22,983 & 1,701 & 7 & 22,091 & 96 \\
\hline Dissolved solids & $500 \mathrm{mg} / \mathrm{L}$ & SS & 15,621 & 4,518 & 29 & 15,620 & 100 \\
\hline \multicolumn{8}{|c|}{ TRACE ELEMENTS } \\
\hline Dissolved arsenic & $50 \mu \mathrm{g} / \mathrm{L}$ & MCL & 5,580 & 28 & $<0.1$ & 4,532 & 81 \\
\hline Dissolved iron & $300 \mu \mathrm{g} / \mathrm{L}$ & SS & 11,035 & 1,147 & 10 & 6,326 & 57 \\
\hline Dissolved lead & $15 \mu \mathrm{g} / \mathrm{L}$ & MCL & 2,235 & 105 & 5 & 379 & 17 \\
\hline Dissolved manganese & $50 \mu \mathrm{g} / \mathrm{L}$ & SS & 9,563 & 1,962 & 21 & 4,635 & 48 \\
\hline Dissolved selenium & $50 \mu \mathrm{g} / \mathrm{L}$ & MCL & 5,590 & 55 & 1 & 4,061 & 73 \\
\hline \multicolumn{8}{|c|}{ RADIOLOGICAL } \\
\hline Radium-226 & ns & ns & 399 & na & na & 295 & 74 \\
\hline Radium-228 & ns & ns & 175 & na & na & 62 & 35 \\
\hline $\begin{array}{l}\text { Radium-226 plus } \\
\text { Radium-228 }\end{array}$ & $5 \mathrm{pCi} / \mathrm{L}$ & MCL & 173 & 10 & 6 & 129 & 74 \\
\hline Radon & $300 \mathrm{pCi} / \mathrm{L}$ & PMCL & 545 & 375 & 69 & 542 & 99 \\
\hline Uranium & $20 \mu \mathrm{g} / \mathrm{L}$ & PMCL & 5,089 & 460 & 9 & 4,855 & 96 \\
\hline \multicolumn{8}{|c|}{ VOLATILE ORGANIC COMPOUNDS ${ }^{3}$} \\
\hline Benzene & $5 \mu \mathrm{g} / \mathrm{L}$ & MCL & 445 & 0 & 0 & 7 & 2 \\
\hline Carbon tetrachloride & $5 \mu \mathrm{g} / \mathrm{L}$ & MCL & 568 & 3 & 0.5 & 6 & 1 \\
\hline Ethylbenzene & $700 \mu \mathrm{g} / \mathrm{L}$ & MCL & 445 & 0 & 0 & 6 & 1 \\
\hline Vinyl chloride & $2 \mu \mathrm{g} / \mathrm{L}$ & MCL & 483 & 3 & $<0.1$ & 3 & 1 \\
\hline \multicolumn{8}{|c|}{ BACTERIOLOGICAL } \\
\hline Total coliforms & $5.0 \%^{4}$ & MCL & 307 & -- & -- & 54 & 18 \\
\hline
\end{tabular}

${ }^{1}$ Except for trace elements, data summarized include both filtered and unfiltered samples. In general, filtered and unfiltered samples should yield similar results for most constituents in ground water. For trace elements, only filtered samples are included and results are for the dissolved phase because substantial concentrations of trace elements can occur in both the dissolved and the suspended phases.

${ }^{2}$ U.S. Environmental Protection Agency, 1996.

${ }^{3}$ Finished drinking-water data not included in volatile organic compound data set.

${ }^{4}$ No more than 5.0 percent of samples total coliform-positive in a month. 
cyanazine, and simazine) had observations exceeding a water-quality standard, and except for atrazine, rates of exceedance were smaller than 0.1 percent of observations. Atrazine, the most commonly used pesticide, had the most exceedances (62 exceedances; 1.4 percent of observations) and was detected in 25 percent of all observations. A large number of observations are available for dissolved solids, which is a direct measure of salinity. The secondary standard of $500 \mathrm{mg} / \mathrm{L}$ for dissolved solids was exceeded in 29 percent of the 15,621 observations. Two constituents that contribute to salinity, chloride and sulfate, had about 10 percent of observations exceeding their secondary standard (250 mg/L). Among trace elements, iron and manganese most often exceeded a standard: 10 percent of iron observations exceeded the secondary standard of 300 micrograms per liter ( $\mu \mathrm{g} / \mathrm{L})$, and 21 percent of manganese observations exceeded the secondary standard of $50 \mu \mathrm{g} / \mathrm{L}$. Among trace elements with an MCL, lead had the largest exceedance rate (5 percent), and arsenic and selenium had exceedance rates of 1 percent or less. These trace elements were commonly detected, with lead having the smallest detection rate of 17 percent. Among radiological parameters in the data set, only radium226 plus radium-228 currently has a drinking-water standard. Although 10 of the 173 observations in the data set exceeded the MCL of 5 picocuries per liter, an insufficient number of observations are in the data set to evaluate the status of radium as a water-quality concern. Similarly, although 69 percent of observations for radon exceeded a proposed standard of 300 picocuries per liter, there are insufficient observations to evaluate radon as a water-quality concern. Among radiological parameters, the most observations are available for uranium because uranium analyses were done as part of the NURE program; however, as discussed in the "Content of Retrospective Data Base" section, the NURE sites are not uniformly distributed across the study area. Among sites with uranium data, the proposed water-quality standard of $20 \mu \mathrm{g} / \mathrm{L}$ was exceeded for 9 percent of the observations. Insufficient data are available to evaluate volatile organic compounds as a water-quality concern. Only about 500 observations are available for 4 volatile organic compounds having MCL's listed in table 8; the frequency of detections and exceedances for volatile organic compounds as a group is somewhat less than that for pesticides as a group. There were insufficient observations in the data set for total coliforms to evaluate the status of bacteria as a water-quality concern; however, coliform bacteria were detected in 18 percent of the 307 observations in the data set.

The data from table 8 indicate that the retrospective data base has sufficient data to corroborate that nitrate and dissolved-solids (salinity) concentrations are substantial water-quality concerns. A moderate amount of available retrospective data also indicate that among pesticides, atrazine detections are a concern. The retrospective data indicate that iron, manganese, fluoride, uranium, and radon might warrant concern in some areas. In the sections that follow, retrospective data for these constituents are examined in more detail. Data for the other constituents listed in table 8 are insufficient to warrant detailed data analysis.

\section{Nitrate}

Nitrate is a form of nitrogen that is one among a group of substances called nutrients, which are substances essential to the growth of plants. However, excessive nutrients can be deleterious to the environment, supporting excessive growths of algae and aquatic plants in surface waters, and nitrate can accumulate in ground water and become a human-health concern (Mueller and Helsel, 1996). Nitrate tends to accumulate in ground water where there are substantial sources of nitrogen applied to the land surface because nitrate is highly soluble in water and is stable over a wide range of aerobic environmental conditions.

Sources of nitrogen to the land surface in the High Plains study area include natural, atmospheric, agricultural, and urban sources. The principal natural source of nitrogen is provided by plants converting atmospheric nitrogen gas to organic nitrogen (nitrogen fixing). Organic nitrogen in plants can then be converted (mineralized) to nitrate by natural degradation processes. This natural source of nitrogen generally leads to a small, stable background nitrate concentrations in ground water, although temporary increases may occur when natural vegetation is converted to cropland.

The remaining sources of nitrogen are anthropogenic (human-derived) sources that result from agricultural and urban land use. Primary among these is the application of manure and fertilizer to the land surface (fig. 9). Nationwide, the application of nitrogen in fertilizer has increased twentyfold from 
1945 to 1993 (Puckett, 1995) and is widespread in the High Plains, where cropland now amounts to an estimated 50 million acres (U.S. Department of Agriculture, 1999). Manure from livestock is a second important agricultural source of nitrogen. Together, manure and fertilizer sum to an average application rate across the entire High Plains study area of 34 pounds of nitrogen per acre per year. Anthropogenic and natural sources of nitrogen also can be recycled by uptake into the atmosphere and reapplied to the land surface in the form of nitrate and ammonia dissolved in rainfall; the average annual nitrogen load in the High Plains study area from precipitation is about 3.5 pounds per acre, equivalent to a concentration in rainfall of about $0.7 \mathrm{mg} / \mathrm{L}$ nitrogen (National Atmospheric Deposition Program, 2000). Additional sources of nitrate occur from residential and urban wastewater, which is conveyed to stream channels through wastewater-treatment plants or to the ground through septic systems. Due to the low population density in the High Plains, wastewater is not a large component of the total nitrogen loading but can be an important factor locally in stream channels downstream from wastewater-treatment plants and in areas where septic systems are concentrated or are functioning improperly.

Because nitrogen sources are common in the High Plains study area, it might be expected that a portion would be transported to aquifers. The bulk of the nitrogen applied is incorporated into the tissue of growing plants, but residual nitrogen can accumulate in soils beneath fields and move into aquifers when transport mechanisms are present. Data from the retrospective data base indicate that nitrate is the dominant form of nitrogen in the High Plains study area (table 7). While the median nitrite plus nitrate concentration in the High Plains retrospective data base was $3.0 \mathrm{mg} / \mathrm{L}$, the median ammonia concentration was $0.02 \mathrm{mg} / \mathrm{L}$, the median nitrite concentration was less than the detection limits of $0.01 \mathrm{mg} / \mathrm{L}$, and the median organic nitrogen concentration was $0.3 \mathrm{mg} / \mathrm{L}$. Nitrite can be an important nitrogen species where dissolved oxygen concentrations are small. In the retrospective data set, the median concentration of dissolved oxygen was $4.8 \mathrm{mg} / \mathrm{L}$, indicating overall aerobic conditions in the High Plains aquifer. The smallest median dissolved oxygen concentrations (1.7 and $1.8 \mathrm{mg} / \mathrm{L}$ ) occurred in shallower Valley-Fill Alluvium and Nebraska Sand Hills units, while larger concentrations (medians of $5.4 \mathrm{mg} / \mathrm{L}$ or larger) occurred in the deeper Ogallala Formation-North,
Arikaree-Brule Formations, and Nebraska Quaternary Deposits units. In the retrospective data set nitrite concentrations are inversely related to dissolved oxygen concentrations, with nitrite concentrations exceeding $0.1 \mathrm{mg} / \mathrm{L}$ found only where dissolved oxygen concentrations are less than $1 \mathrm{mg} / \mathrm{L}$. In the 70 wells in which nitrite concentrations exceeded $0.1 \mathrm{mg} / \mathrm{L}$, nitrite was still a minor constituent, averaging 16 percent of the nitrite plus nitrate concentration in those wells. Because nitrite concentrations were small, in the discussion that follows, nitrate observations and nitrite plus nitrate observations will be grouped together and referred to as nitrate.

All nitrate data in the retrospective data base were selected and grouped by decade to examine temporal changes in nitrate concentrations for the study area. To ensure that spatial variability was not a factor in this analysis, sites sampled during each decade were mapped, and a visual verification was made that the study area had a reasonable distribution of sampling sites during each decade. So that single wells were not overrepresented where multiple samples were taken, a median concentration was selected for each well for each decade. Boxplots of the decadal data (fig. 11) indicate that nitrate concentrations in the study area started to increase beginning in the 1970's. Differences in median nitrate concentrations were verified using the Wilcoxon rank-sum test ( $\mathrm{p}=0.0001$ ), and Tukey's multiple comparison test ( $\alpha=0.05)$ indicated that median concentrations weresimilar from the 1930's to the 1960's, significantly larger in the 1970's, and larger yet in the 1980's and 1990's. The median nitrate concentration from the 1930 's to the 1960's was $1.7 \mathrm{mg} / \mathrm{L}$ and may be representative of background levels. The median nitrate concentration in the 1980's and 1990's was $3.2 \mathrm{mg} / \mathrm{L}$.

To examine temporal changes in nitrate within each hydrogeologic unit, the decadal data set was stratified by hydrogeologic unit, and a LOWESS smooth line was calculated for each unit (fig. 12). Data distribution was sufficient for each decade within each hydrogeologic unit except for the Nebraska Sand Hills, where few data were available prior to the 1970's. These data indicate that nitrate concentrations are increasing at varying rates in most of the hydrogeologic units in the study area. Units with a large percentage of irrigated lands (Valley-Fill Alluvium, Nebraska Quaternary Deposits) have the largest nitrate concentrations and the largest increases in nitrate concentrations. Large increases have also occurred in 


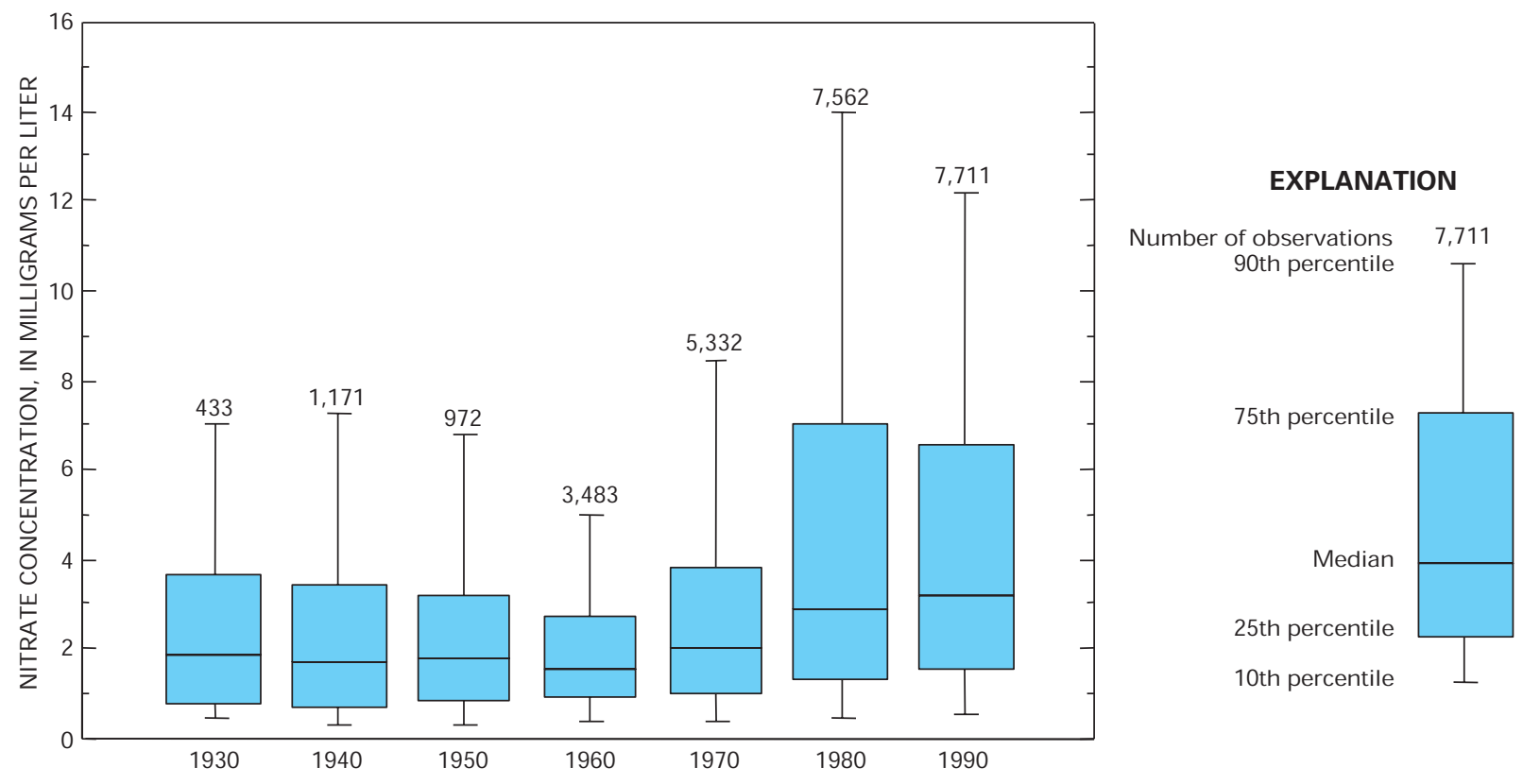

Figure 11. Distribution of nitrate concentrations, by decade.

the Arikaree-Brule Formations unit, which has a moderate depth to water. Nitrate concentrations in the shallow Kansas Quaternary Deposits unit have generally been large throughout the period of record. Among the Ogallala Formation units, the two with shallower depth to water (Ogallala Formation-North and Ogallala Formation-South units) have had larger increases in nitrate concentrations than the deeper Ogallala Formation-Central unit. To test for statistical significance of these changes, the Wilcoxon rank-sum test was used to test for nitrate concentration differences between grouped 1930-69 data and grouped 1980-98 data for each unit (except for the Nebraska Sand Hills which had insufficient data). Data from the transitional 1970's decade were excluded from this analysis. Significant differences were found for all units except for the Kansas Quaternary Deposits.

To examine temporal variability of nitrate concentrations at a more local geographic scale, differences between grouped 1930-69 data and grouped 1980-98 data nitrate concentrations were evaluated for each county. Where more than one observation was available for a well during a grouped time period, a median value was used for that well before a median was calculated for the county. The change in county median concentration between the two periods is displayed in figure 13A. There were 167 counties that had an increase in median nitrate concentrations between these two time periods and 41 counties that had no change or a decrease. The Wilcoxon rank-sum test indicated that county increases were statistically significant for 93 counties, while decreases were statistically significant for only 4 counties. The remaining counties had insufficient data (generally fewer than 20 observations) for the statistical test. Counties with increases in nitrate concentrations are distributed throughout the study area. Largest

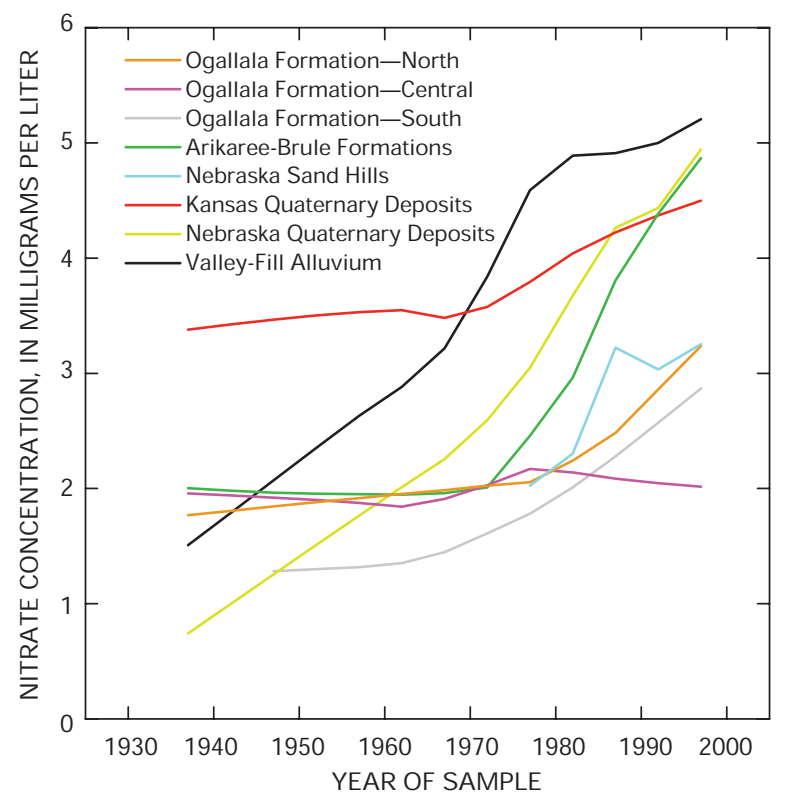

Figure 12. Temporal variability of nitrate concentrations, by hydrogeologic unit. 

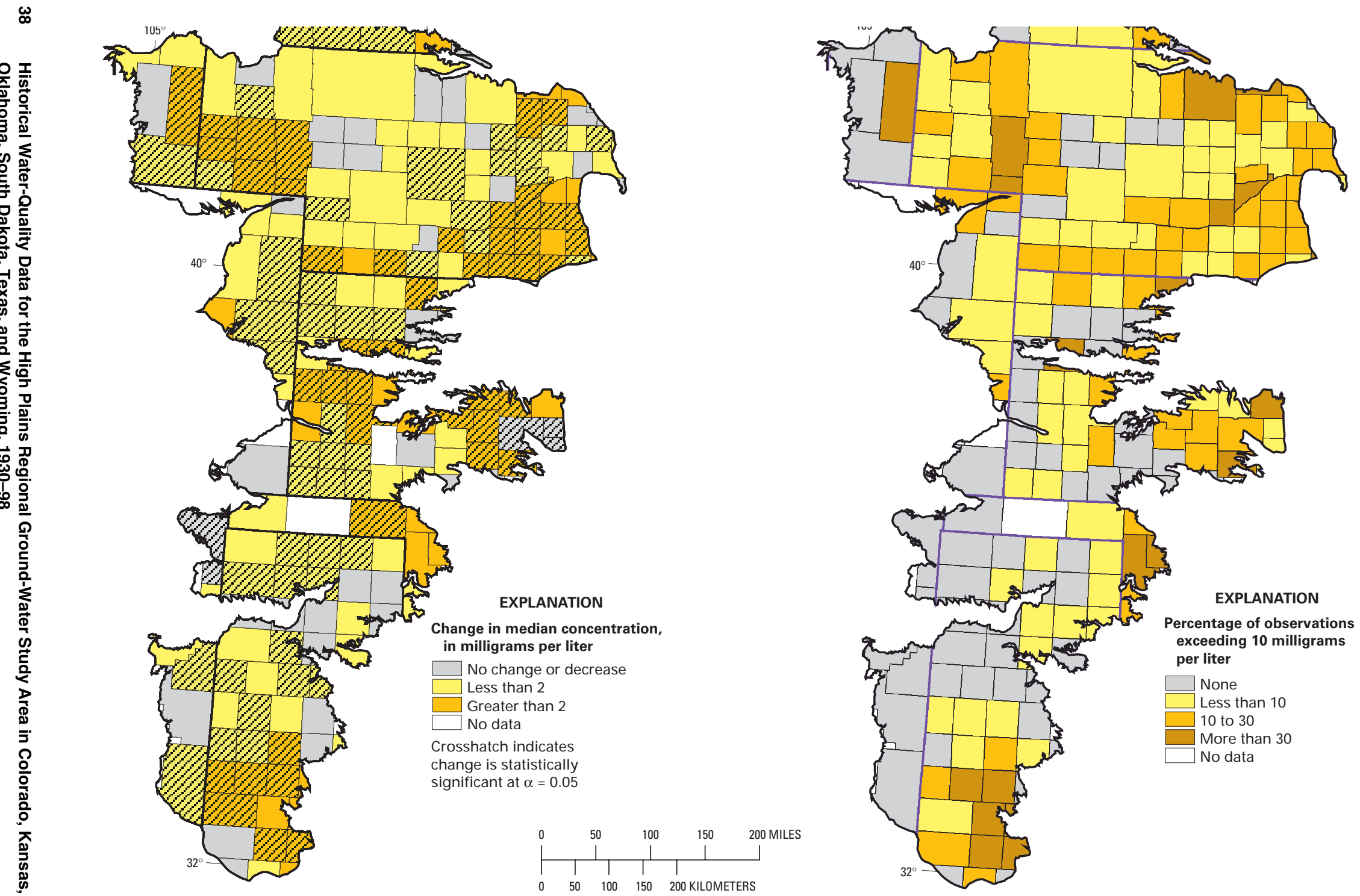

A. Change in median nitrate concentration

(1930-69 median compared to 1980-98 median)

B. Percentage of observations exceeding

10 milligrams per liter (1980-98)

Figure 13. Distribution of nitrite concentrations by decade. 
increases have occurred in counties along the major river valleys, in eastern Nebraska and central Kansas, and in the southern part of the study area in Texas. The county changes show that there is some variability within hydrogeologic units. For example, although concentrations have increased significantly in the Ogallala Formation-South unit, the changes are largest in the southern part of this unit; and although changes in the Ogallala Formation-Central unit have been small, there are counties within this area where changes have been large. These differences within hydrogeologic units indicate that there are factors within units that affect nitrate concentrations. Areas where nitrate increases have been largest generally were in contiguous groups of counties, which might indicate that causative factors are fairly widespread, as might be expected with nonpoint-source factors.

Among the 1980-98 data, the percentage of nitrate observations exceeding the $10 \mathrm{mg} / \mathrm{L} \mathrm{MCL}$ for each county (fig. 13B) indicates that exceedance rates greater than 10 percent are widespread and occur throughout Nebraska, in central Kansas, and in the southern part of the study area in Texas. Exceedance rates larger than 30 percent are more scattered and occur in 19 counties. In some areas, such as the southern part of the study area in Texas and in the eastern part of the study area in Nebraska, multicounty areas have both large increases in nitrate concentrations and large rates of exceedance of the MCL; these characteristics have been attributed to high nitrogen application rates and sandy soils (Exner and Spalding, 1990; Reeves and Miller, 1978). In contrast, in some areas nitrate increases were small, but rates of exceedance of the 10-mg/L MCL were large. In one such area, Holt County in north-central Nebraska, this has been attributed to point-source contamination of poorly constructed wells (Exner and Spalding, 1990).

Data from the retrospective data base were next evaluated for relations between nitrate concentrations and well-site characteristics. Because there is temporal variability in the data, only data from the recent period (1980-98) were used, and because there is variability based on hydrogeologic unit, tests were done separately for each unit. Where multiple observations were available for a well, only the most recent observation was used.

Differences in median values for categorized data were tested using the Kruskal-Wallis test, and groupings were identified using the Tukey multiple comparison test. Significant differences in nitrate concentrations were determined based on well type. Wells constructed for water withdrawal had significantly larger nitrate concentrations than did observation wells in hydrogeologic units where depth to water was small (Valley-Fill Alluvium, Nebraska Sand Hills, Kansas Quaternary Deposits, and Arikaree-Brule Formations). However, there was no significant difference in nitrate concentrations between these two well types in the deeper units. This may indicate that construction techniques are more variable for shallow water wells, with poorly constructed wells susceptible to surface contamination, while deeper wells may be more likely to be better constructed regardless of the well type. Water use of a well was not found to be a significant factor for nitrate concentrations except in the Ogallala Formation units, where water from livestock wells had smaller nitrate concentrations than did water from wells used for irrigation or domestic purposes. Land use was a significant factor for nitrate concentrations in five of the units (Kansas Quaternary Deposits, Arikaree-Brule Formations, and the three Ogallala Formation units); in four of these hydrogeologic units, nitrate concentrations were smaller under rangeland than under other land uses. However, in the Ogallala Formation-South unit, nitrate concentrations were larger under urban land use and rangeland than under agricultural land use.

Nitrate concentrations were tested for relations with continuous numerical variables by using the Kendall's tau correlation coefficient (table 9). Each of the correlation coefficients shown in this table is significant ( $p=0.0001$ ), but the correlations are weak, which is indicative of the large amount of variability in the data, perhaps due to natural variation in the environmental setting within the large geographic extent of the study area. Well depth was inversely correlated with nitrate concentrations in five of the eight hydrogeologic units, indicating that deeper wells are less likely to have large nitrate concentrations. However, estimated depth to water was inversely correlated with nitrate concentrations in only three of the eight hydrogeologic units, with the stronger correlations in the Ogallala Formation-Central and Ogallala FormationSouth. This may indicate that depth to water is important only for the deeper aquifers, while in the shallow aquifers, depths to water are everywhere small enough so as to be susceptible to contamination. For the Nebraska Sand Hills, nitrate concentrations were directly correlated with estimated depth to water; the reason for this is not known. 
Table 9. Kendall's tau correlation coefficients between nitrate concentrations and ancillary variables by, hydrogeologic unit

[Correlations shown only if the magnitude is greater than 0.10; all correlations shown are significant with $\mathrm{p}=0.0001$; --, no correlation]

\begin{tabular}{|c|c|c|c|c|c|c|c|}
\hline Hydrogeologic unit & $\begin{array}{c}\text { Estimated } \\
\text { depth to water }\end{array}$ & $\begin{array}{l}\text { Well } \\
\text { depth }\end{array}$ & $\begin{array}{c}\text { Depth of } \\
\text { sample } \\
\text { below } \\
\text { water table }\end{array}$ & $\begin{array}{l}\text { Irrigation } \\
\text { intensity }\end{array}$ & $\begin{array}{l}\text { Nitrogen } \\
\text { input }\end{array}$ & $\begin{array}{c}\text { Soil } \\
\text { permeability }\end{array}$ & $\begin{array}{l}\text { Age of } \\
\text { well }\end{array}$ \\
\hline Ogallala Formation-North & -- & -- & -0.17 & -- & -- & -- & -- \\
\hline Ogallala Formation-Central & -0.27 & -0.23 & -- & -- & 0.17 & 0.26 & -- \\
\hline Ogallala Formation—South & -0.38 & -0.34 & -- & -0.20 & -0.13 & 0.32 & -- \\
\hline Arikaree-Brule Formations & -0.13 & -0.19 & -0.26 & 0.26 & 0.31 & 0.15 & -- \\
\hline Nebraska Sand Hills & 0.19 & -- & -- & 0.30 & 0.26 & -- & -- \\
\hline Kansas Quaternary Deposits & -- & -- & -- & 0.11 & -0.16 & -- & -- \\
\hline Nebraska Quaternary Deposits & -- & -0.15 & -0.24 & -- & -- & -- & 0.14 \\
\hline Valley-Fill Alluvium & -- & -0.16 & -0.17 & 0.25 & -- & 0.14 & -- \\
\hline
\end{tabular}

For 5,300 wells, information was available about the perforated interval of the well, and a depth of sample below the water table could be calculated by subtracting the depth of the midpoint of the open interval from the depth to water. In general, larger nitrate concentrations might be expected where the depth of the sample below the water table is small (near the top of the aquifer) because this is the first portion of the aquifer to be in contact with substances transported down from the land surface. This variable inversely correlated with nitrate concentrations in four hydrogeologic units, but correlation coefficients were still relatively small (maximum magnitude of -0.26 ). The strength of this correlation might be weakened by inaccuracies in calculating the depth of the sample below the water table: some of the open intervals were quite large, and for many wells the depth-to-water measurement may not have been taken at the time of sampling. The relation between nitrate concentrations and depth of the sample below the water table is shown graphically in figure 14 . For six of the hydrogeologic units, nitrate concentrations decrease as depth of the sample below the water table increases. The slope of this relation is quite large for the Nebraska Quaternary Deposits, Valley-Fill Alluvium, and Arikaree-Brule Formations units and smaller for the Ogallala Formation-North, Ogallala FormationCentral, and Nebraska Sand Hills units. In contrast, nitrate concentrations appear to increase and then decrease with depth of sample below the water table for the Kansas Quaternary Deposits and Ogallala Formation-South units. This pattern might be due to processes such as denitrification in shallower environ- ments or flushing of nitrates deeper into the aquifer, or it might be a relic of the data base due to the relatively small number of points used in the analysis (only 51 data points are available for the Kansas Quaternary Deposits, but 875 points are available for the Ogallala Formation-South).

Irrigation intensity was directly correlated with nitrate concentrations in four hydrogeologic units where depths to water were shallow. Irrigation intensity was not correlated with nitrate concentrations in the deeper Ogallala Formation units, except in the Ogallala Formation-South unit where nitrate concen

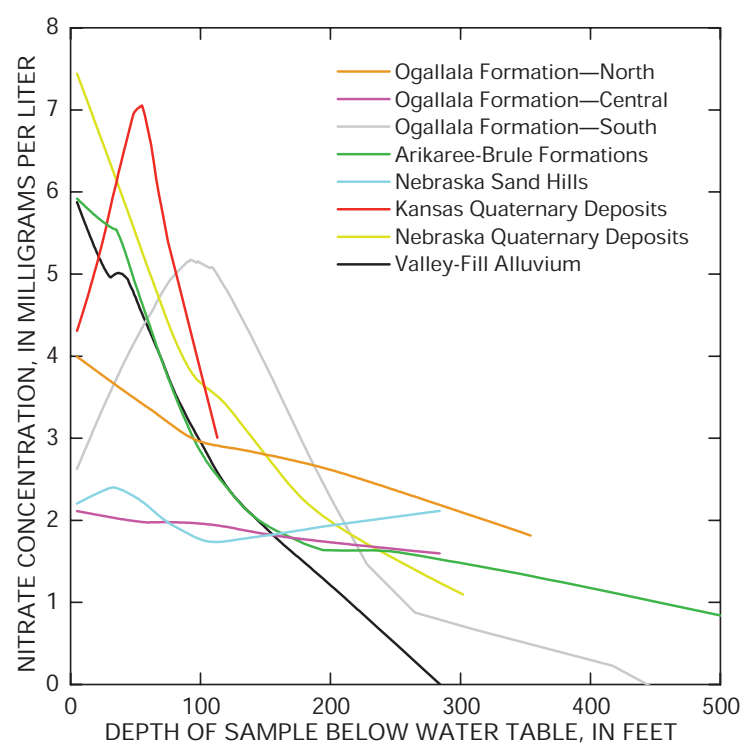

Figure 14. Relation between nitrate concentration and depth of sample below water table, by hydrogeologic unit. 
trations were larger where irrigation intensity was less; this finding seems in agreement with the land-use results for the Ogallala Formation-South where nitrate concentrations were smaller in agricultural land use than in other land uses. In this unit other factors such as the location of focused recharge from playa lakes may affect contamination of the aquifer (Mullican and others, 1994).

Nitrogen inputs were most strongly correlated with nitrate concentrations in the two hydrogeologic units (Arikaree-Brule Formations and Nebraska Sand Hills) where agricultural land use is minimal; correlations were poorer and inconsistent in intensive agricultural areas. This may indicate that county-wide estimates of nitrogen inputs are not site-specific enough or variable enough to be useful predictors of nitrate concentrations within areas where there is abundant agricultural activity. Soil permeability was correlated with nitrate concentrations in four hydrogeologic units, with correlations large in the Ogallala Formation-Central and Ogallala Formation-South units. Age of well was weakly correlated with nitrate concentrations in one hydrogeologic unit, the Nebraska Quaternary Deposits.

In general, ancillary variables were best correlated with nitrate concentrations in the Ogallala Formation-Central, Ogallala Formation-South, Arikaree-Brule Formations, and Nebraska Sand Hills. Correlations were generally poor for the remaining units, especially for the Ogallala Formation-North unit. These poor correlations probably reflect the large variability of geographic and site-specific well characteristics even within the individual hydrogeologic units. Error also is contributed by assignment of geographic characteristics using generalized maps to make up for the lack of site-specific information. Additional site-specific information, such as information about potential contamination pathways and processes, might be needed to accurately predict which areas are susceptible to nitrate contamination.

\section{Pesticides}

During the past 40 years, the use of pesticides to enhance crop growth has become widespread. For example, the nationwide use of atrazine has been estimated to have increased ninefold between 1964 and 1974 (Barbash and others, 1999). The use of some pesticides has declined as improved products are developed; for example, the use of alachlor decreased fourfold between 1975 and 1992. Also, health and environmental concerns have caused the use of some pesticides, such as dieldrin, to be canceled.

Each of 43 pesticides were applied to crops at an estimated annual rate of 100,000 pounds or more of active ingredient in the High Plains study area during 1992 (Gail Thelin, U.S. Geological Survey, written commun., 1999). The most commonly used pesticides, ranked by pounds of active ingredient applied and by number of acres treated, are listed in table 10. The herbicide atrazine is the most commonly used pesticide by both measures, with about 9.5 million pounds applied to 8.8 million acres. Atrazine use is widespread in the High Plains study area because it is used on three (corn, wheat, and sorghum) of the four principal crops in the study area. Other common herbicides are metolachlor, 2,4-D, alachlor, cyanazine, and trifluralin. Common insecticides are chlorpyrifos, terbufos, methyl parathion, and carbofuran. Pesticides are most heavily applied in areas where irrigation is most intense in eastern Nebraska, southwest Kansas, and the panhandle of Texas. At least 30 pesticides are applied in most counties, and more than 60 pesticides are applied in counties in the panhandle of Texas and in areas of western Nebraska where crop diversity is large. A few types of pesticides (such as permethryn, which is produced by the chrysanthemum plant and which has a commonly used synthetic derivative called permethrin) have natural sources, but the pesticides discussed in this report are synthetic compounds with no natural sources; therefore, their presence in the environment may be attributed to anthropogenic sources.

Over 94,000 pesticide observations are in the retrospective data base with 2,436 pesticide detections, and the overall detection rate is about 2.6 percent. About 50 pesticides were detected in the High Plains study area, but only 11 pesticides were detected at 10 or more sites. The most commonly detected pesticides, based on number of sites having detections, are listed in table 10. A comparison of the most commonly used pesticides with those most commonly detected indicates that use and occurrence in ground water generally are correlated. Atrazine was the most commonly used pesticide and also is by far the most commonly detected pesticide (detected in 24.8 percent of all tested samples and detected at 578 sites). Metolachlor, 
Table 10. Most commonly used and detected pesticides in the High Plains study area

[Insecticides appear in bold, other chemicals are herbicides. Source of use data: Gail Thelin, U.S. Geological Survey, written commun., 1999; detection rank is based on number of sites having a detection]

\begin{tabular}{rlll}
\hline Rank & $\begin{array}{c}\text { Pesticide use in 1992 } \\
\text { based on pounds active } \\
\text { ingredient applied }\end{array}$ & $\begin{array}{c}\text { Pesticide use in 1992 } \\
\text { based on number of } \\
\text { acres treated }\end{array}$ & $\begin{array}{c}\text { Pesticide detected in the High Plains } \\
\text { retrospective data base } \\
\text { (number of sites having detections is } \\
\text { in parentheses) }\end{array}$ \\
\hline 1 & Atrazine & Atrazine & Atrazine (578) \\
2 & $2,4-D$ & Metolachlor & Metolachlor (70) \\
3 & Metolachlor & $2,4-D$ & Simazine (68) \\
4 & Dicamba & Alachlor & Prometon (63) \\
5 & Alachlor & Cyanazine & Alachlor (38) \\
6 & Metsulfuron & Trifluralin & Propazine (35) \\
7 & Trifluralin & Chlorpyrifos & Cyanazine (35) \\
8 & Chlorpyrifos & Terbufos & Trifluralin (20) \\
9 & Methyl parathion & Acetochlor & $2,4,5-T P(17)$ \\
10 & Chlorsulfuron & Methyl parathion & Tebuthiuron (16) \\
11 & Cyanazine & Butylate & Metribuzin (10) \\
12 & Permethrin & EPTC & $2,4-D(8)$ \\
13 & Terbufos & Carbofuran & Chlorpyrifos (6) \\
14 & Carbofuran & Pendimethalin & Diazinon (4) \\
15 & Picloram & Propachlor & Dieldrin (3) \\
\hline
\end{tabular}

alachlor, cyanazine, and trifluralin also are ranked high on the lists of pesticides applied and number of acres treated and are ranked high on the list of pesticides detected. Each of these is a herbicide used on corn and other crops in the study area. Three of the most commonly detected pesticides (prometon, simazine, propazine) are triazine-type herbicides like atrazine but do not appear on either list of most commonly used pesticides in table 10. Prometon and simazine are commonly used for bare-ground weed control on noncropped areas in agricultural and other land-use settings, but few data are available on the total amounts used. Among nationwide pesticide studies, prometon was the second most commonly detected pesticide after atrazine, and simazine was the fourth most commonly detected pesticide (Barbash and Resek, 1996). Propazine is a commonly used herbicide on sorghum, but its use was canceled during 1988-98; therefore, its use was not tabulated in the 1992 estimates. The herbicide 2,4,5-TP was commonly used to control weeds on rangeland and pastureland, but its use was canceled in 1985 due to health concerns; its detection in the High Plains study area is limited to a small area in one county in New Mexico. Tebuthiuron (used to control weeds in noncropland areas) and metribuzin (used to control weeds on cropland and fallow land) are ranked 98th and 38th in pounds applied in the High Plains study area, respectively; but due to their high solubility in water and low sorption potential to soils, they have a high ground-water contamination potential. Their detection in the High Plains study area is limited to a scattered few counties. The herbicide 2,4-D is the second most commonly applied pesticide in the study area but only the twelfth most commonly detected pesticide. This may be because 2,4-D rapidly degrades in soil and aquatic environments. Chlorpyrifos, diazinon, and dieldrin are the only insecticides on the most-detected list in table 10. Chlorpyrifos is commonly used but sorbs strongly to soils and is not readily soluble in water. Diazinon is not a commonly used pesticide by amount applied or acres treated but is the most commonly used household insecticide (Whitmore and others, 1992). The use of dieldrin wascanceled in 1987, but it is occasionally detected in ground water because it is persistent in the environment.

Pesticide data have been commonly collected in the High Plains study area only since the mid-1980's (fig. 4). Since 1985, the annual percentage rate of pesticide detections has varied from 1 percent to 8 
percent of measurements made, but there is no pattern of increasing rates of pesticide detections. This is probably due to the variety of pesticide analytical methods that have become available over the years, which includes highly sensitive methods (such as high pressure liquid chromatography) and less sensitive field-screening techniques (such as immunoassay analysis). Over the decades, the median pesticide detection limit in the retrospective data base has increased, probably due to the increased use of immunoassay field methods. For these reasons it is not possible to evaluate temporal trends in pesticide concentrations or detections using the High Plains retrospective data base.

Sites with pesticide data, sites with detections, and sites with concentrations exceeding drinkingwater standards are shown in figure 15 for the four most commonly detected pesticides. For each of the four pesticides, data primarily are available only in the northern half of the study area. Sixty percent of sites with atrazine detections, 59 percent of sites with metolachlor detections, 80 percent of sites with simazine detections, and 86 percent of sites with prometon detections were in the Valley-Fill Alluvium hydrogeologic unit. The frequency of detection of pesticides was also largest in the Valley-Fill Alluvium unit; for example, atrazine was detected at 49 percent of the sites sampled in the Valley-Fill Alluvium unit. The number of sites with pesticide detections and the frequency of detection generally were second largest in the Nebraska Quaternary Deposits unit. Pesticides were detected much less commonly in the deeper Ogallala Formation units. In the Ogallala FormationNorth unit, atrazine was detected at 24 of 677 sites sampled; in the Ogallala Formation-Central unit, atrazine was detected at 11 of 90 sites sampled; and in the Ogallala Formation-South unit, atrazine was detected at 4 of 170 sites sampled. However, the detection of pesticides in deeper aquifers indicate that contamination pathways exist.

Atrazine concentrations exceeded the USEPA drinking-water maximum contaminant level at 37 sites. Nineteen of these sites were in the Valley-Fill Alluvium hydrogeologic unit, where 2.7 percent of the sites sampled had an atrazine exceedance. Twelve sites in the Nebraska Quaternary Deposits unit had atrazine exceedances (1.7 percent of the sites sampled). Two sites in the deeper Ogallala Formation units had atrazine concentrations exceeding the standard. There were no sites where metolachlor or prometon concen- trations exceeded a standard and only one site where simazine exceeded a standard. The pesticide data from the retrospective data base indicate that among hydrogeologic units the shallow Valley-Fill Alluvium is the most susceptible to pesticide contamination. Each of the four most commonly detected pesticides was detected in the Valley-Fill Alluvium unit along the Platte River. Atrazine also was detected in the ValleyFill Alluvium unit along the South Platte River and the Republican River. Corn is the predominant crop in the Nebraska Quaternary Deposits unit where atrazine also was commonly detected. However, the atrazine detection and exceedance rates are about half as large in the Nebraska Quaternary Deposits unit as in the Valley-Fill Alluvium unit; this difference might be related to the median depth to water for these two units (table 1).

About 75 percent of the pesticide data in the retrospective data base are from sites in Nebraska and central Kansas, so relations identified in the data are not representative of the High Plains study area as a whole. Nebraska pesticide data have been discussed at some length by Exner and Spalding (1990), and Kansas pesticide data have been discussed by Helgesen and others (1994). In the retrospective data base, the percentage of atrazine detections in a county was significantly correlated $(r=0.324 ; \mathrm{p}<0.001)$ to the percentage of nitrate exceedances in the county. Atrazine detections were significantly larger in areas of agricultural land use than in rangeland use and were significantly larger where the principal crop was corn or sorghum. About 30 percent of the variance in atrazine detections was explained by well depth and pesticide application rate.

Recent reconnaissance sampling in the central and northern High Plains (McMahon, 2000; Kolpin and others, 1998) has indicated that pesticide degradate compounds are often more prevalent in the environment than are parent compounds. The principal degradate compounds available in the retrospective data base are by-products of atrazine, namely deethylatrazine and deisopropylatrazine. In the retrospective data base, deethylatrazine had a higher rate of detection (43 percent) than did atrazine (24.8 percent), but deisopropylatrazine had a smaller rate of detection (6 percent). As with atrazine, the by-product detections occurred almost exclusively in the Valley-Fill Alluvium hydrogeologic unit. 

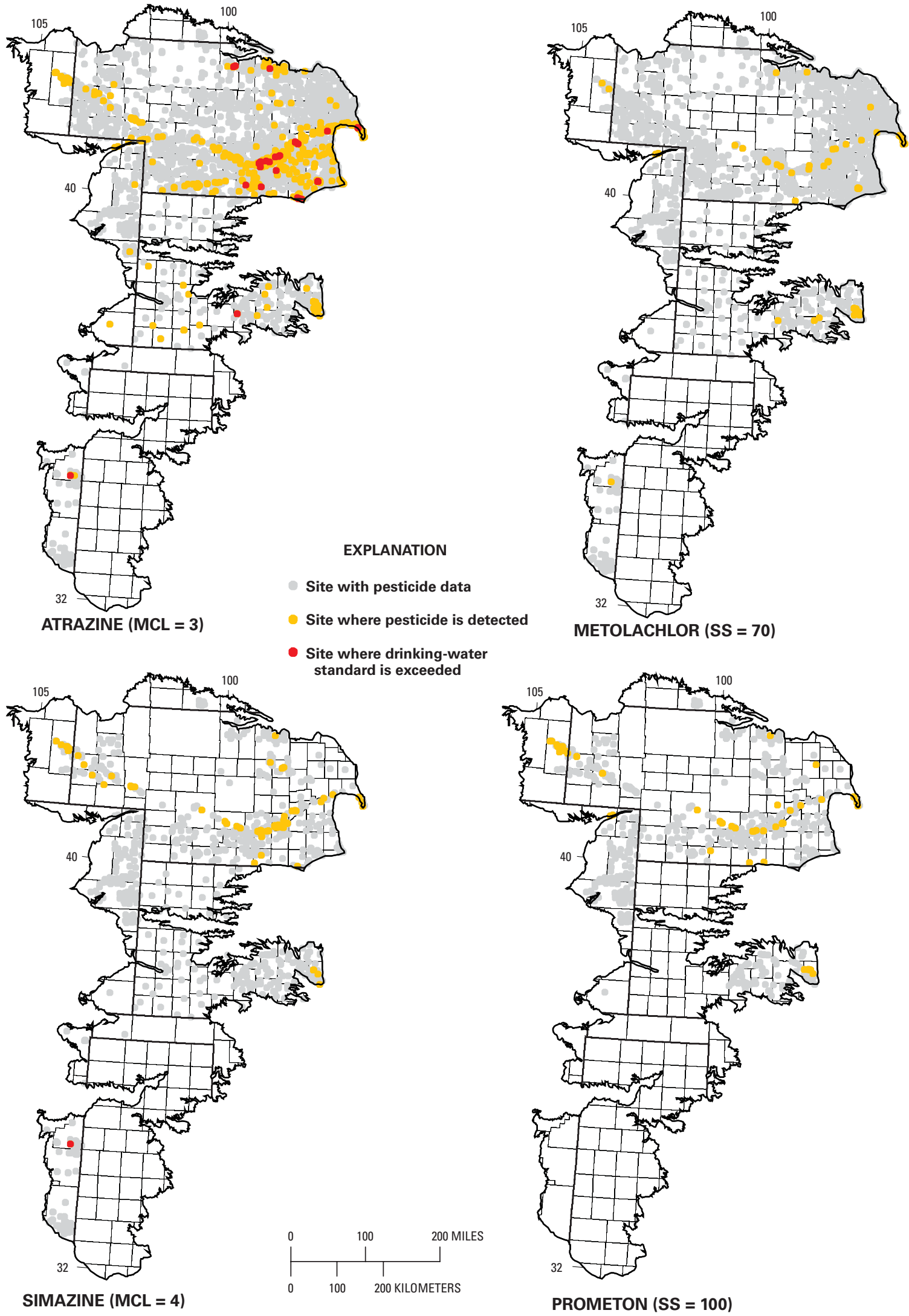

Figure 15. Locations of sites with pesticide data and pesticide detections for atrazine, metolachlor, simazine, and prometon.

44 Historical Water-Quality Data for the High Plains Regional Ground-Water Study Area in Colorado, Kansas, Nebraska, New Mexico, Oklahoma, South Dakota, Texas, and Wyoming, 1930-98 


\section{Dissolved Solids}

Dissolved solids, or salinity, refers to the quantity of mineral salts dissolved in water. Excessive salinity impairs the use of water both for irrigation and for human consumption. A common measure of salinity is dissolved-solids concentration. The USEPA secondary drinking-water standard for dissolved solids is $500 \mathrm{mg} / \mathrm{L}$ (U.S. Environmental Protection Agency, 1996), although water with concentrations as large as 2,000 to $3,000 \mathrm{mg} / \mathrm{L}$ is sometimes tolerated. Similarly, in agricultural use, most crops can flourish in water containing as much as $500 \mathrm{mg} / \mathrm{L}$ dissolved solids and with proper management practices may tolerate water with concentrations as large as 2,250 mg/L (U.S. Environmental Protection Agency, 1976). Also relevant to irrigation and domestic use of water are the concentrations of the chemical constituents that together constitute dissolved solids. The major chemical constituents that constitute dissolved solids are calcium, magnesium, sodium, potassium, bicarbonate, chloride, and sulfate. Chloride and sulfate have secondary drinkingwater standards of $250 \mathrm{mg} / \mathrm{L}$, and fluoride has a secondary drinking-water standard of $2 \mathrm{mg} / \mathrm{L}$ (U.S. Environmental Protection Agency, 1996). Excessive concentrations of sodium relative to concentrations of calcium and magnesium are harmful to plants and soil and are quantified using a measure called the sodiumadsorption ratio.

The constituents that constitute dissolved solids are all natural substances. They occur in varying amounts in soils and rocks and are sometimes naturally concentrated in the form of minerals such as gypsum (calcium sulfate). Ground water naturally increases in dissolved solids as it moves through earth materials by partially dissolving the minerals, and the natural salinity of water can vary greatly depending on whether the material through which it flows is easily soluble (for example, gypsum) or insoluble (for example, sandstone). The sand, gravel, and clay that compose the High Plains aquifer generally do not contain saline minerals, so the salinity of High Plains ground water is generally small. However, older, underlying bedrock units such as Permian-age formations may contain considerable amounts of saline minerals; the ground water that flows through these older rocks can discharge upward into the High Plains aquifer and thereby increase the salinity of High Plains water.

Land-use activities, in particular irrigated agriculture, can have a large effect on dissolved-solids concentrations. As crops grow, their roots selectively uptake nearly pure water and leave behind in the residual water all of the salts present in the original water; this more saline water can then infiltrate downward into ground water. In addition, as unused irrigation water infiltrates downward into ground water, minerals present in the soil are dissolved. The salinity of water generally increases as the exposure of water to rocks and soils increases. Irrigation increases water exposure by the annual recycling process of pumping and infiltration of excess water back into the ground. Additional sources of salinity are pumped oil-field brines and human and animal wastewater.

As was done for the nitrate data, all dissolvedsolids data in the retrospective data base were selected and grouped by decade to examine temporal changes in dissolved-solids concentrations for the study area as a whole. Boxplots of the decadal data (fig. 16) indicate that dissolved-solids concentrations have not changed greatly within the High Plains aquifer as a whole. Concentrations were largest during the 1930's, but the number of observations during the decade was rela-

To examine temporal changes in dissolvedsolids concentrations within each hydrogeologic unit, the decadal data set was stratified by hydrogeologic unit, and a LOWESS smooth line was calculated for each unit (fig. 17). Dissolved-solids concentrations historically have been large in the Valley-Fill Alluvium unit and in the Ogallala Formation-South unit and have been less than the secondary drinking-water standard in the remaining units. Dissolved-solids concentrations have increased slightly in all of the hydrogeologic units except for the Ogallala Formation-South, where concentrations appear to have decreased slightly. However, when the data are tested for significance using the Wilcoxon rank-sum test, differences between 1930-69 and 1980-98 are significant only for the Valley-Fill Alluvium, Ogallala Formation-North, and Ogallala Formation-South units. The apparent trends for the other units cannot be verified statistically due to the large variability in concentrations among samples. The increase in dissolved-solids concentrations is largest in the ValleyFill Alluvium unit, where the median concentration of 


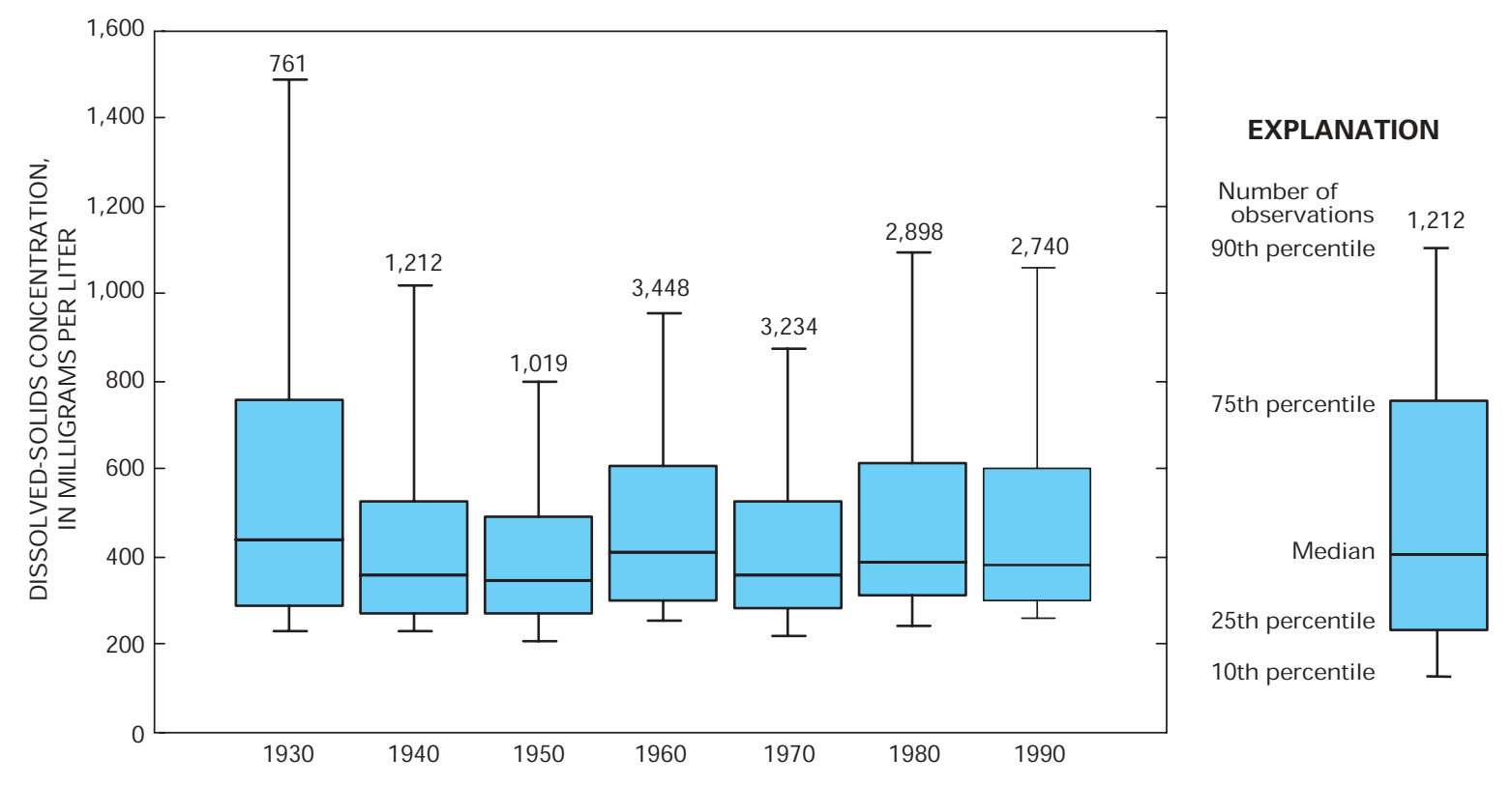

Figure 16. Distribution of dissolved-solids concentrations, by decade.

dissolved solids for $1980-98(603 \mathrm{mg} / \mathrm{L})$ is in excess of the secondary drinking-water standard. The ValleyFill Alluvium unit is susceptible to increasing salinity because irrigation water is recycled along alluvial valleys in a downstream direction as water is pumped from the aquifer or diverted from the river, applied to fields, and then returned to the aquifer as irrigation drainage. During each irrigation/return flow cycle, salinity is increased as water is transpired by crops and as return-flow water dissolves additional minerals from the soil. Whittemore (Kansas Geological Survey, oral commun., 1999) has calculated that sulfate concentrations in the Arkansas River and its alluvial aquifer could increase by a factor of 2 in the next 40 years due to this recycling process. Dissolvedsolids concentrations historically have been in excess of the drinking-water standard in the Ogallala Formation-South unit. In this area, excessive concentrations

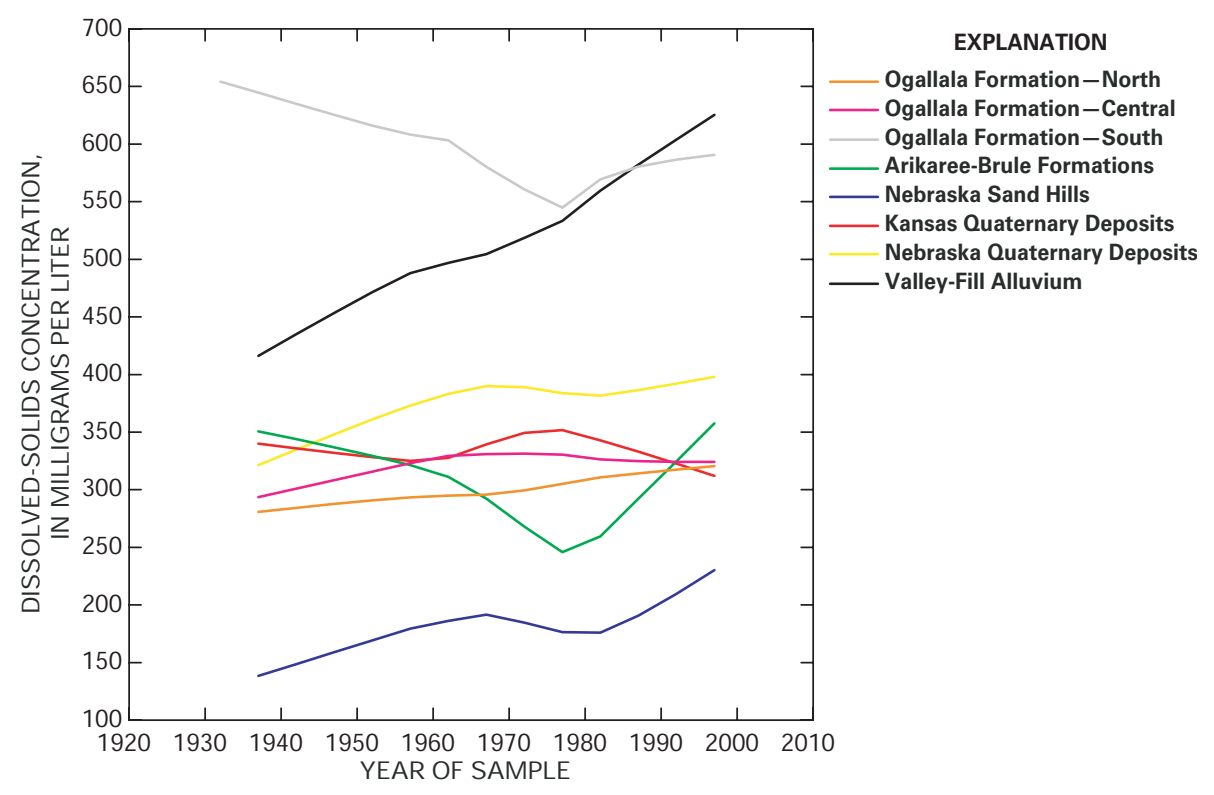

Figure 17. Temporal variability of dissolved-solids concentrations, by hydrogeologic unit. 
have been attributed both to saline water discharging to the aquifer from underlying bedrock units and to the effects of agricultural land use (Reeves and Miller, 1978). The decrease in dissolved-solids concentrations in this unit might partly be an artifact of more dense sampling of wells during 1940-50 in the southern part of the unit (where salinity is larger) than in the northern part of the unit (where salinity is smaller).

To examine temporal variability of dissolvedsolids concentrations at a more local geographic scale, a dissolved-solids concentration map was constructed from the High Plains retrospective data base by using data from 1980-98; this concentration map was compared to a similar map constructed by Krothe and others (1982) using data prior to 1980 (fig. 18). The concentration maps indicate that there is considerable variation of dissolved-solids concentrations within hydrogeologic units. Comparison of these maps suggests that dissolved-solids concentrations have increased in the vicinities of the alluvial valleys of the Platte River, the Republican River, and the Arkansas River. In the Ogallala Formation-South hydrogeologic unit, the size of areas having dissolved-solids concentrations larger than $500 \mathrm{mg} / \mathrm{L}$ has increased. Also, dissolved-solids concentrations have increased in the Colorado portion of the Ogallala Formation-North unit.

Data from the retrospective data base were next evaluated to test for relations between dissolved-solids concentrations and site characteristics. Because there is temporal variability in the data, only data from the recent period (1980-98) were used, and because there is variability based on hydrogeologic unit, tests were done separately for each unit. Where multiple observations were available for a well, only the most recent observation was used. Differences were verified using the Wilcoxon rank-sum test and identified using the Tukey multiple comparison test. Well type (observation or water-withdrawal) was not a significant factor relative to dissolved-solids concentrations. Water-use type was a significant factor in two units (Ogallala Formation-Central and Ogallala Formation-South), where domestic wells had significantly larger dissolved-solids concentrations than did wells used for other purposes. Land use was a significant factor in four units (Kansas Quaternary Deposits and the three Ogallala Formation units), where dissolved-solids concentrations were larger for wells in urban land use than for wells in other land uses. Underlying bedrock was a significant factor in four units. In three units
(Nebraska Sand Hills, Ogallala Formation-North, and Ogallala Formation-Central), dissolved-solids concentrations were larger at sites underlain by Late Cretaceous-age rocks than at sites underlain by other geologic units. In the Ogallala Formation-South, dissolved-solids concentrations were larger at sites underlain by Early Cretaceous-age rocks than at sites underlain by other geologic units.

Dissolved-solids concentrations were tested for relations with continuous numerical variables by using the Kendall's tau correlation coefficient (table 11). For wells having sampled-interval information, two additional variables were calculated. Depth of the sample below the water table was calculated as was done with nitrate, and depth of the sample above bedrock was calculated using information about depth to bedrock. Each of the correlation coefficients shown in this table is significant ( $\alpha=0.05$ ), but correlations are generally weak. As with nitrate, dissolved-solids concentrations commonly were inversely correlated with well depth and with depth of the sample below the water table. A significant inverse relation between dissolved-solids concentration and depth of sample above bedrock was observed for three units (Ogallala Formation-South, Nebraska Sand Hills, and Kansas Quaternary Deposits); that is, the closer to bedrock a sample was taken, the larger the dissolved-solids concentration. This may indicate that these three units are susceptible to increased salinity from saline water discharging upward from underlying bedrock units. In contrast with nitrate, dissolved-solids concentrations generally were inversely correlated with soil permeability; that is, dissolved-solids concentrations were larger where soil permeability was low. This might indicate that low-permeability soils are more likely to contain mineral salts.

To examine the composition of dissolved solids in samples from High Plains wells, data were extracted from the High Plains data base for wells that had complete major ion analyses. All available historical data were used in order to evaluate the major ion chemistry of each hydrogeologic unit. For wells that were sampled more than once, the best-quality data were selected; data quality was evaluated by calculating a charge balance for each water analysis and by using the analysis with the best charge balance. Boxplots of major ion composition for each hydrogeologic unit (fig. 19) indicate that all of the units are calcium bicarbonate type waters but that there is some variability in water types among the units. The 

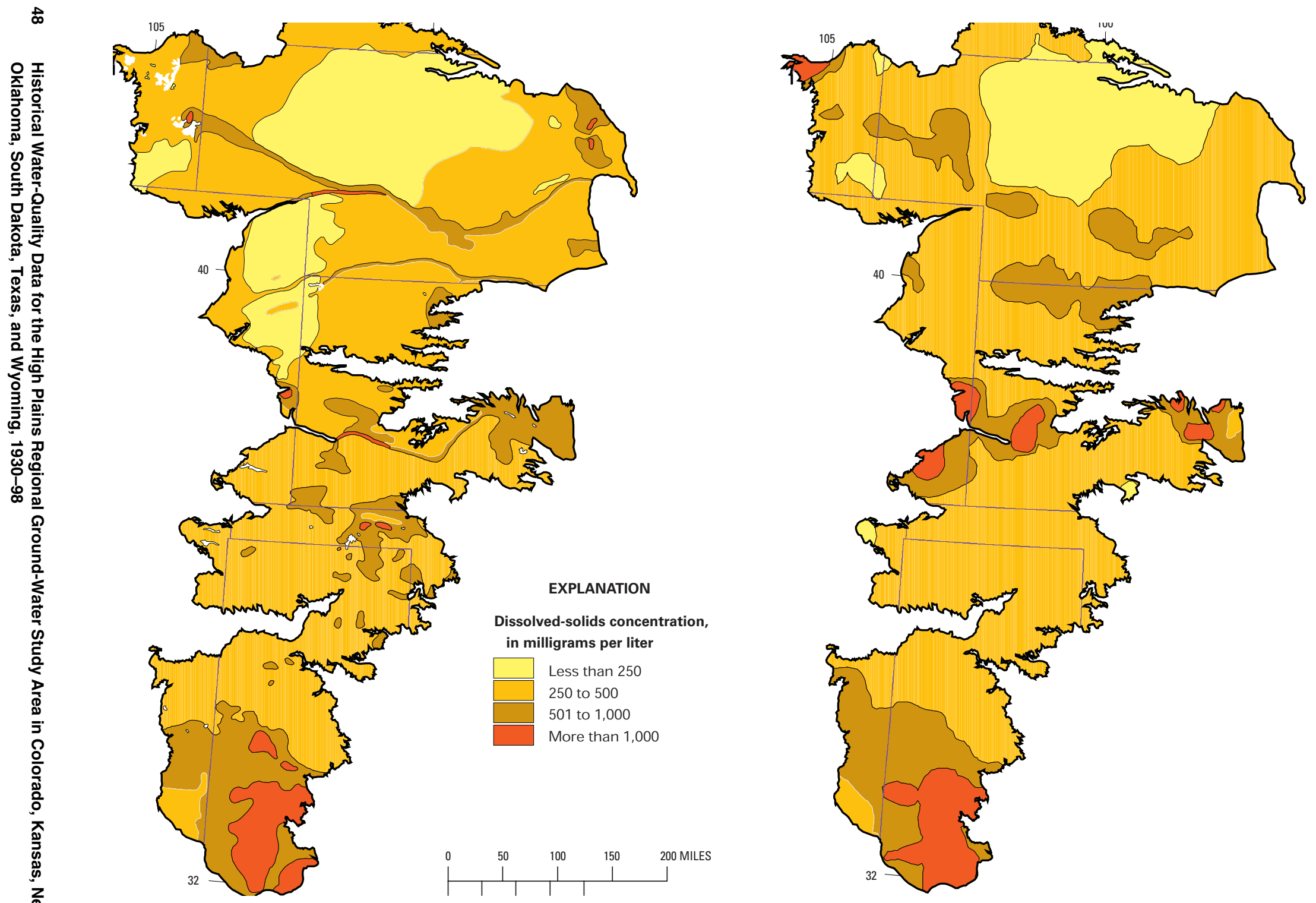

Figure 18. Geographic distribution of dissolved-solids concentrations: data prior to 1980 and data after 1980 
Table 11. Kendall's tau correlation coefficients between dissolved-solids concentrations and ancillary variables, by hydrogeologic unit

[Correlations shown only if the magnitude is greater than 0.10; all correlations shown are significant at $\alpha=0.05$; --, no correlation]

\begin{tabular}{|c|c|c|c|c|c|c|c|c|}
\hline $\begin{array}{c}\text { Hydrogeologic } \\
\text { unit }\end{array}$ & $\begin{array}{l}\text { Estimated } \\
\text { depth to } \\
\text { water }\end{array}$ & $\begin{array}{l}\text { Well } \\
\text { depth }\end{array}$ & $\begin{array}{c}\text { Depth of } \\
\text { sample } \\
\text { below } \\
\text { water } \\
\text { table }\end{array}$ & $\begin{array}{l}\text { Depth of } \\
\text { sample } \\
\text { above } \\
\text { bedrock }\end{array}$ & $\begin{array}{l}\text { Irrigation } \\
\text { intensity }\end{array}$ & $\begin{array}{c}\text { Nitrogen } \\
\text { input }\end{array}$ & $\begin{array}{c}\text { Soil } \\
\text { permeability }\end{array}$ & $\begin{array}{l}\text { Age of } \\
\text { well }\end{array}$ \\
\hline Ogallala Formation—North & -- & -0.27 & -0.17 & -- & -- & -- & -0.16 & 0.11 \\
\hline Ogallala Formation-Central & -- & -- & -- & -- & -- & -- & -- & -- \\
\hline Ogallala Formation—South & -0.45 & -0.46 & -0.06 & -0.13 & -0.24 & -0.18 & 0.40 & -- \\
\hline Arikaree-Brule Formations & -- & -0.10 & -0.14 & -- & -- & -0.14 & -0.15 & -- \\
\hline Nebraska Sand Hills & -- & -0.24 & -- & -0.45 & 0.33 & 0.39 & -0.30 & -- \\
\hline Kansas Quaternary Deposits & -- & -- & -0.12 & -0.17 & -- & -- & -0.38 & -- \\
\hline Nebraska Quaternary Deposits & -- & -- & -- & -- & 0.19 & 0.15 & -0.18 & -- \\
\hline Valley-Fill Alluvium & -- & -0.12 & -0.34 & 0.24 & -- & -0.12 & -- & -- \\
\hline
\end{tabular}

Nebraska Sand Hills water is the simplest water type, consisting almost entirely of calcium and bicarbonate, and Ogallala Formation-South water is most complex, having substantial proportions of all the major ions except potassium. Sulfate concentration is large in Ogallala Formation-South water and Valley-Fill Alluvium water but also is a substantial component of Ogallala Formation-North and Kansas Quaternary water. Chloride concentration is largest in Ogallala Formation-South water but also is a substantial component of Kansas Quaternary and Valley-Fill Alluvium water. Chloride is more common than sulfate only in Kansas Quaternary water.

Median concentrations of major ions for each unit as depicted in figure 19 might be considered typical values for background major ion chemistry for the High Plains aquifer waters except for the ValleyFill Alluvium unit where dissolved-solids concentrations have changed substantially over time. Many of the boxplots in figure 19 are symmetrical in shape, which suggests normal distributions of data and water derived under a stable set of natural processes. Water contamination or mixing of water types might be expected where data distributions are skewed, such as for sulfate in the Valley-Fill Alluvium and Ogallala Formation-South units, and sodium and chloride in the Kansas Quaternary Deposits unit. Individual well analyses can be compared to the median values to investigate whether shifts in major ion chemistry have occurred. This type of analysis can be used to detect contamination from human and animal wastes (large chloride concentrations), contamination from agricultural land use (large sulfate concentrations), or contamination from oil-field brines (large sodium and chloride concentrations).

\section{Other Constituents}

Other constituents in the retrospective data base found to have large percentages of exceedances of water-quality standards are iron, manganese, fluoride, radon, and uranium (table 8). Iron is the most abundant metallic element in the Earth's outer crust, manganese is the second-most abundant metal (although it only is about one-fiftieth as common as iron), and fluoride is the most common of the halogen group of elements in rocks. These three constituents are usually considered major solutes in water and will be discussed together. Radon and uranium are radioactive elements, which are not abundant in the Earth's crust, and they will be discussed together.

Iron and manganese are required micronutrients for plants and animals, and fluoride is used by animals in building bones and teeth (Hem, 1992). However, secondary drinking-water standards have been established by the USEPA (U.S. Environmental Protection Agency, 1996) for these constituents (300 $\mu \mathrm{g} / \mathrm{L}$ for iron, $50 \mu \mathrm{g} / \mathrm{L}$ for manganese, and $2 \mathrm{mg} / \mathrm{L}$ for fluoride) because higher concentrations cause stain or taste problems in water. In addition, fluoride has a maximum contaminant level of $4 \mathrm{mg} / \mathrm{L}$ in drinking 

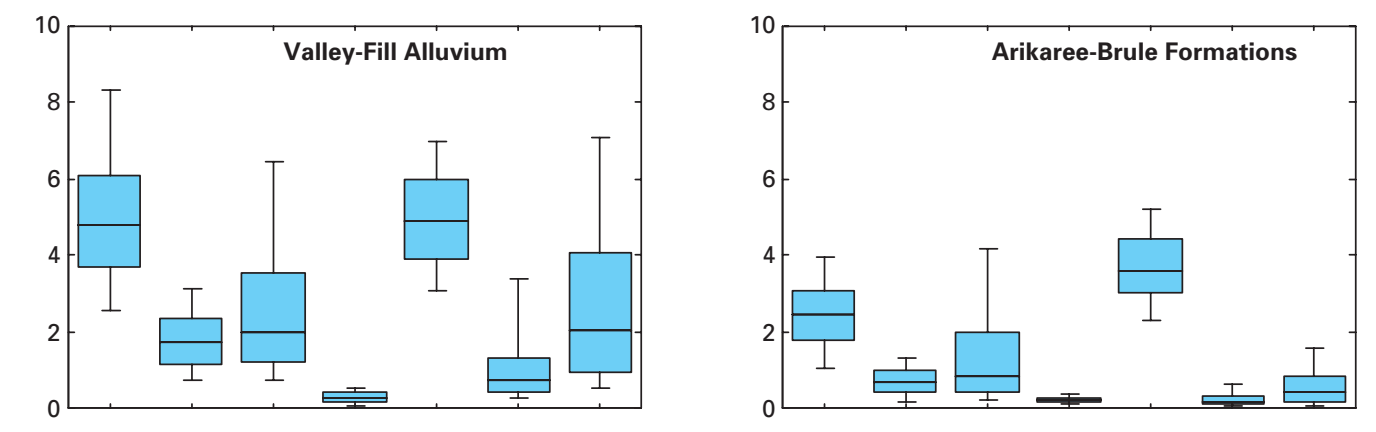

\section{EXPLANATION}

90th percentile

75th percentile

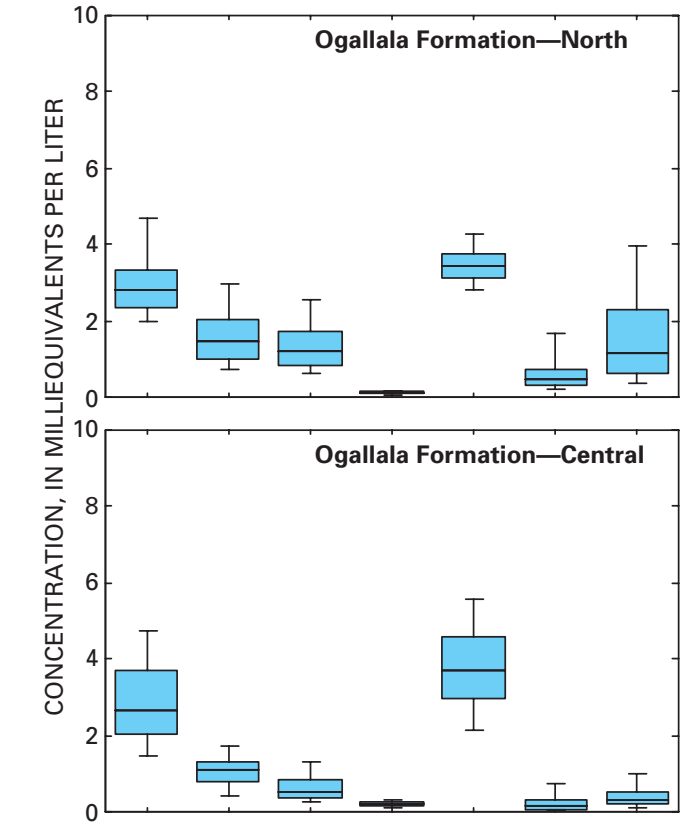

25th percentile 10th percentile $\perp$
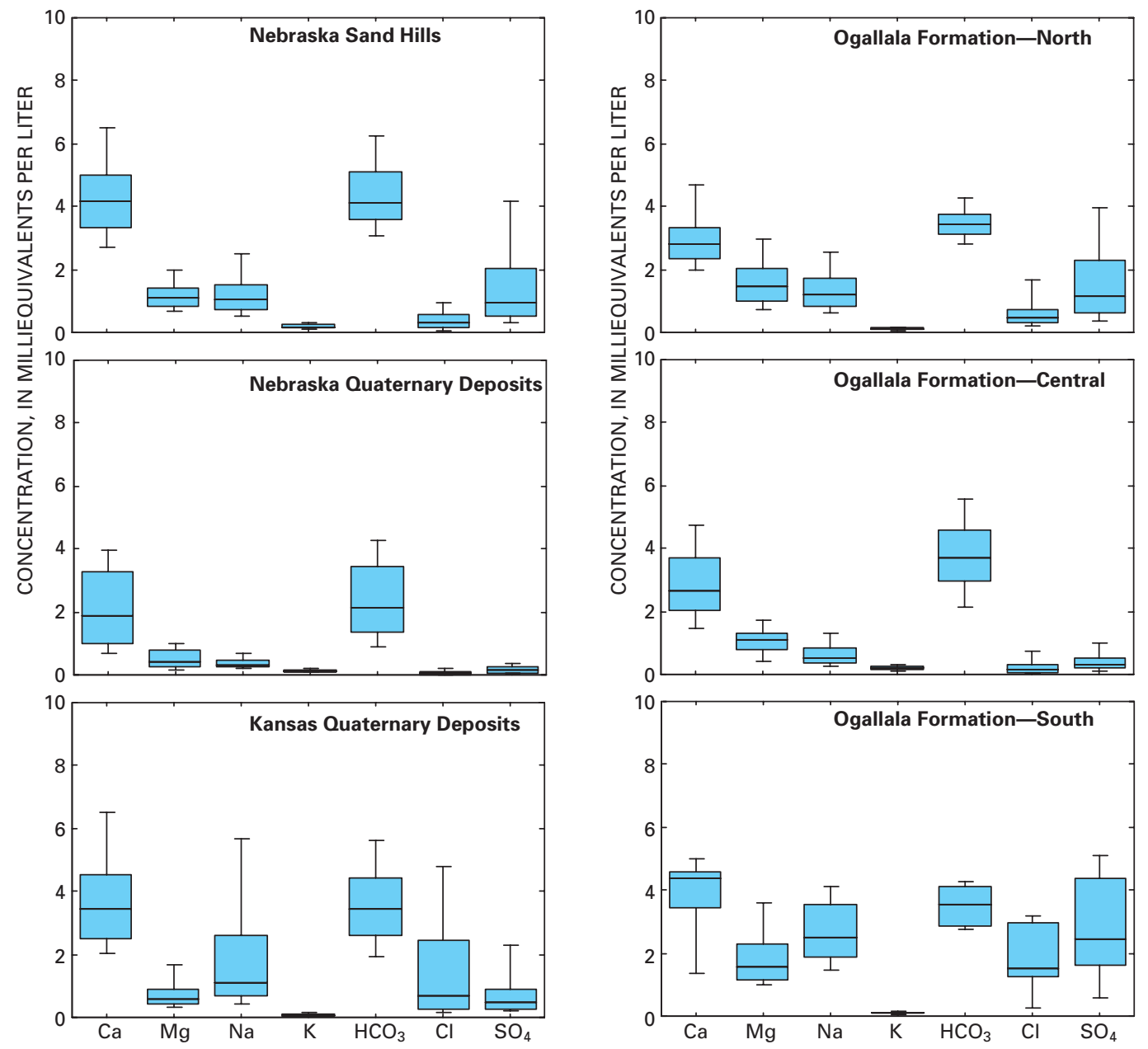

Figure 19. Major ion chemistry of High Plains ground water, by hydrogeologic unit. 
water because it can cause bone disease or mottled teeth in children. Although each of these three constituents has multiple industrial, agricultural, or other human uses, their presence in ground water is generally from natural sources. Human activities can affect iron and manganese concentrations through altering the geochemical environment and causing the trace elements to become more mobile. Well construction can affect concentrations by allowing waters from different aquifers to mix. Iron concentrations in well water can be increased by corrosion of the metallic well casings.

The geographic distributions of exceedances of drinking-water standards for iron, manganese, and fluoride are shown in figure 20. Exceedances for iron were most common in the central part of the study area. Iron concentrations were not significantly different based on well casing type. Manganese exceedances occurred most often in the northern part of the study area, while fluoride exceedances occurred most often in the southern part of the study area.

Radon, a water-soluble gas formed by the radioactive decay of the element radium, is common in small concentrations in ground water. Uranium occurs naturally throughout the Earth's outer crust and generally is present in small concentrations in ground water; elevated concentrations generally are associated with uranium ore deposits. The human intake of radon and uranium is a health concern because both are radioactive substances; uranium also is of concern as a possible toxic chemical substance. Humans are exposed to radon primarily through the air and secondarily through drinking water. Humans are exposed to uranium in drinking water and in food. The USEPA has established proposed drinking-water maximum contaminant levels for radon (300 pCi/L) and uranium $(20 \mu \mathrm{g} / \mathrm{L})$; these levels are under review, and final standards are expected in late 2000. A new proposed rule for radon gas would establish an alternative maximum contaminant level for radon of 4,000 pCi/L for community water systems that have in place a multimedia mitigation program that includes control of radon in air (U.S. Environmental Protection Agency, 1999).

The proposed drinking-water standard for radon $(300 \mathrm{pCi} / \mathrm{L})$ was exceeded in 375 observations, or 69 percent of the total observations in the retrospective data base. The proposed drinking-water standard for uranium ( $20 \mu \mathrm{g} / \mathrm{L})$ was exceeded in 460 observations, or 9 percent of the total observations in the retrospective data base. The occurrence of radon and uranium drinking-water standard exceedances by county is shown in figure 21. Most radon data are from New Mexico, Texas, and the Platte River valley of Nebraska. Within these areas, most exceedances were in New Mexico and in three counties in western Nebraska. The exceedances in Nebraska may be related to volcanic ash in the Brule Formation (Verstraeten and others, 1995). Uranium exceedances were primarily along the Platte River in Nebraska and in one county in southwest Kansas. The large values along the Platte River in western Nebraska have been attributed to oxidizing conditions that favor uranium solubility (Verstraeten and others, 1995). In the Platte River valley in central Nebraska, uranium exceedances have been related to leachates from evaporite deposits in bottomland soils (Spalding and Druliner, 1981). In both areas, the ultimate source of the uranium has been attributed to sediments derived from the ancestral Rocky Mountains and transported downstream by alluvial and colluvial processes. Uranium in the Arkansas River valley in Colorado has been linked to phosphate fertilizers, which can contain trace amounts of uranium (Zielinski and Asher-Bolinder, 1996). 

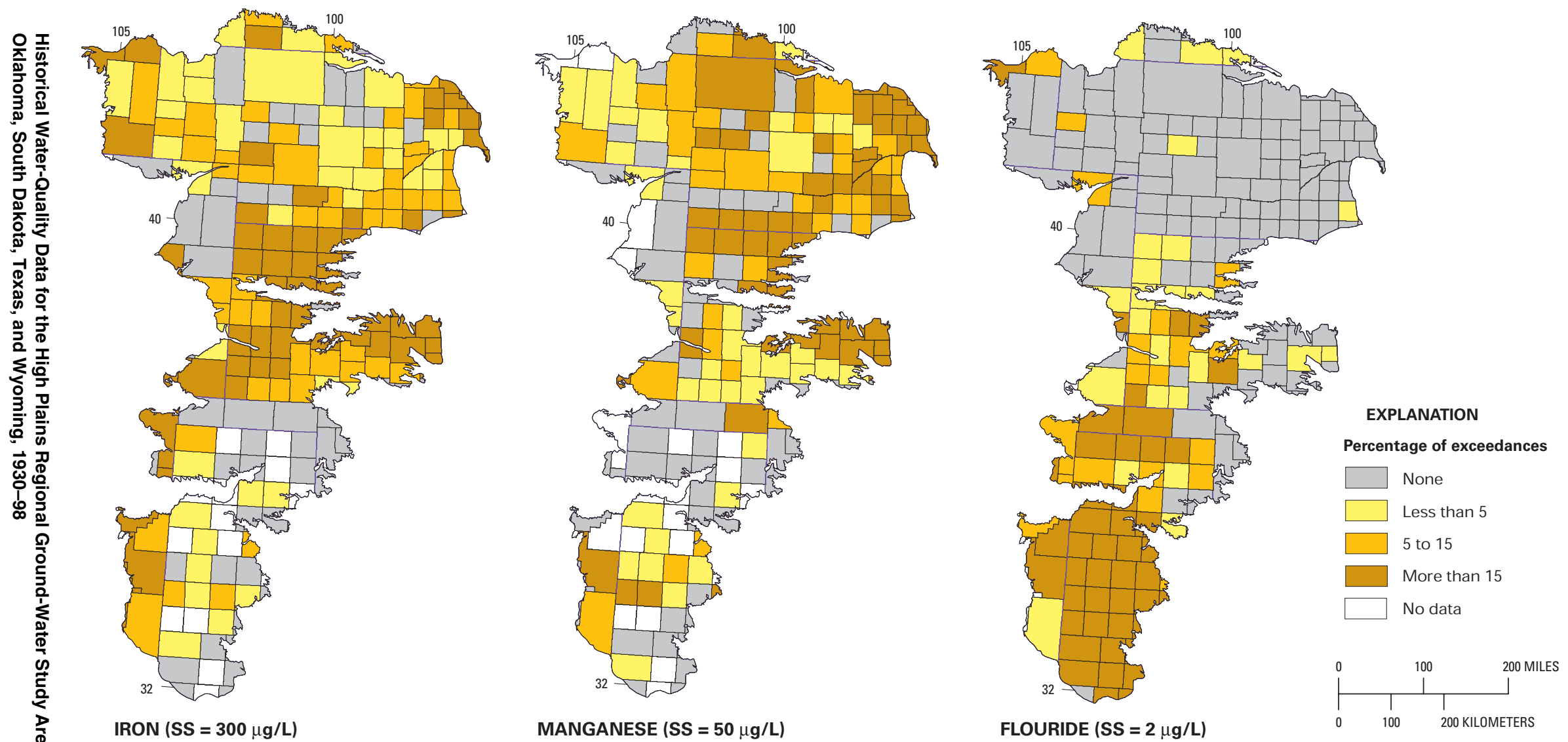

Figure 20. Distribution of the percentage of iron, manganese, and fluoride observations that exceeded drinking-water standards. 


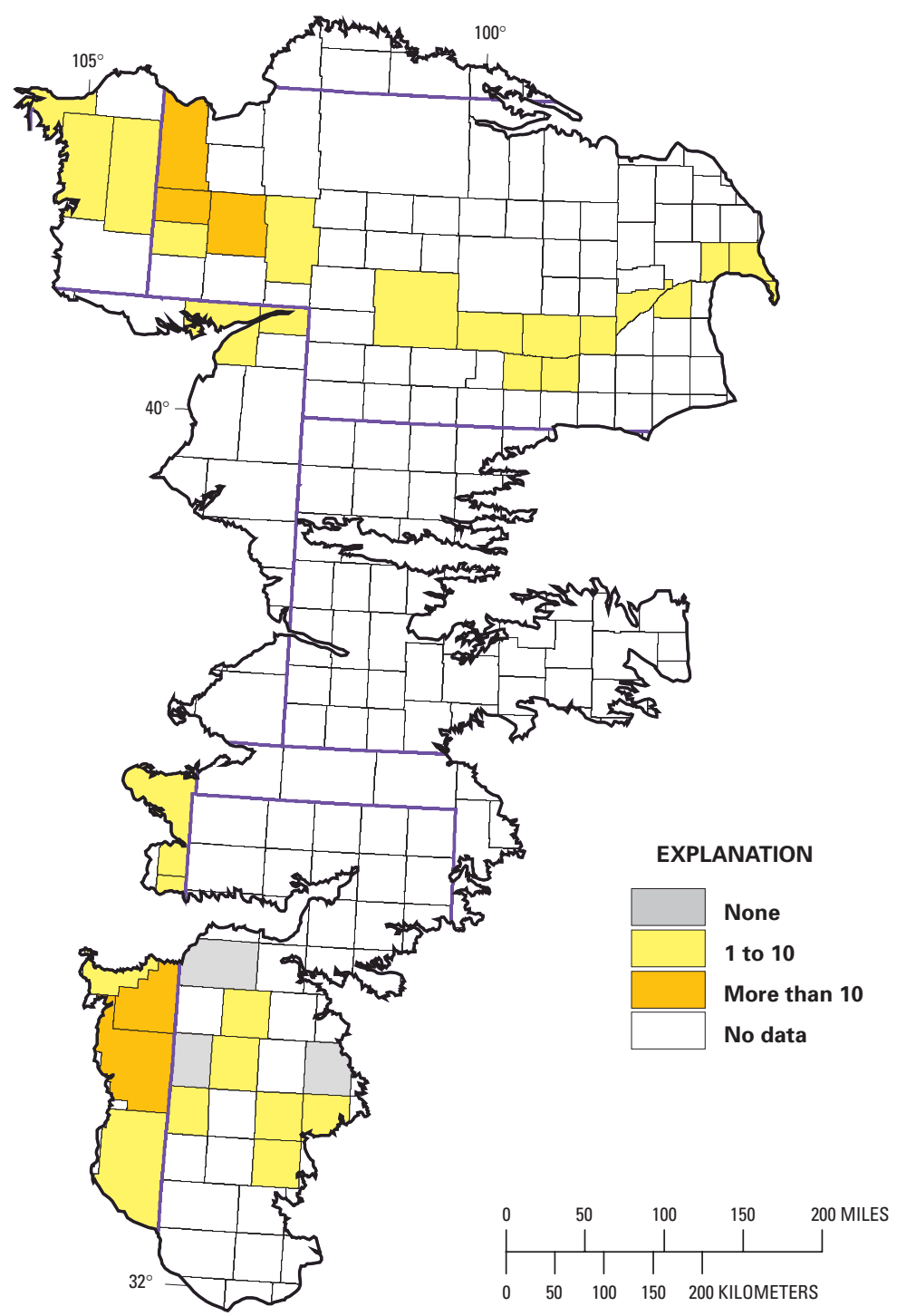

RADON (PMCL $=300 \mathrm{pCi} / \mathrm{L})$

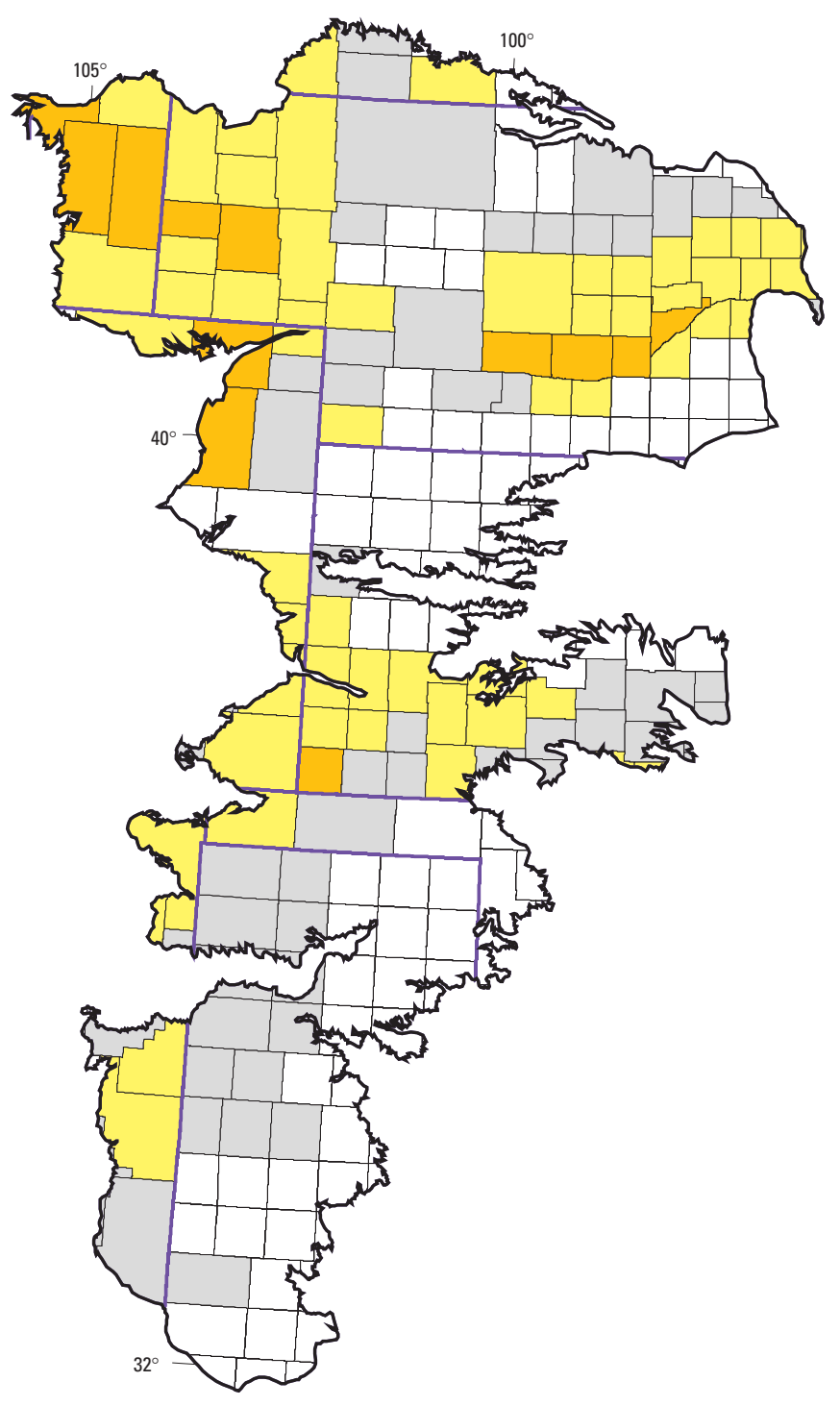

URANIUM (PMCL $=20 \mu \mathrm{g} / \mathrm{L})$

Figure 21. Distribution of the number of radon and uranium observations that exceeded drinking-water standards. 


\section{SUMMARY}

The High Plains aquifer underlies 174,000 square miles in parts of eight States and includes eight primary hydrogeologic units. It includes the wellknown Ogallala Formation and is an important resource, providing water for 27 percent of the Nation's irrigated agricultural lands in this otherwise dry landscape. Since the 1980's there has been concern over the sustainability of the aquifer due to water-level declines caused by substantial pumping. Water quality of the aquifer is a more recent concern. States and local governmental entities have done local studies on water quality, but few aquiferwide assessments have been made. The U.S. Geological Survey National Water-Quality Assessment Program (NAWQA) is an ongoing effort to document water-quality conditions across the United States, and the High Plains Regional Ground-Water Study Area was created as part of NAWQA in 1998.

One of the first elements of the High Plains Regional Ground-Water NAWQA Study was to gather existing historical water-quality data into a retrospective data base, which can be used to evaluate occurrence and distribution of water-quality constituents of concern. Data from 43 agencies were compiled into this data base. In addition to water-quality information, the data base includes well-site information such as well depth, aquifer, underlying bedrock, land use, and agricultural practices. The data base contains water-quality information collected at 29,041 sites. Over one million water-quality observations are present in the data base, with information about 733 different water-quality parameters. Considerable historical information for nitrate and salinity is available for the High Plains study area. However, data for important constituents such as pesticides is more sparse and has poorer spatial and temporal distribution. The historical data base is included in digital form as a companion to this report.

Data from the retrospective data base verify that nitrate, pesticides, and salinity are important waterquality concerns in the High Plains study area. Additional constituents in the retrospective data base found to have large percentages of exceedances of U.S. Environmental Protection Agency drinking-water standards were iron, manganese, fluoride, radon, and uranium.

Sixteen percent of all nitrate observations were larger than the drinking-water standard of $10 \mathrm{mg} / \mathrm{L}$. In six of the eight geohydrologic units and in about 70 percent of the counties within the High Plains study area, nitrate concentrations for the period 1980-98 were significantly larger than for the period 1930-69. While nitrate concentrations are largest in the geohydrologic units with the shallowest depth to water, nitrate concentrations also have increased in the units of the Ogallala Formation where depth to water is large. Relations between nitrate concentrations and well-site characteristics varied among geohydrologic units. Well depth, depth to water, and depth of sample below the water table were related to nitrate concentrations in at least four of the geohydrologic units. Correlations were generally poor and probably reflect the large variability of geographic and site-specific well characteristics even within the individual geohydrologic units. Additional site-specific information, such as information about potential contamination pathways and processes, might be needed to accurately predict which areas are susceptible to nitrate contamination.

About 50 pesticides were detected in the High Plains study area, but only 11 pesticides were detected at 10 or more sites. Only four pesticides (atrazine, alachlor, cyanazine, and simazine) had observations exceeding a water-quality standard. For each of the four pesticides, data primarily are available only in the northern half of the study area. Sixty percent of sites with atrazine detections, 59 percent of sites with metolachlor detections, 80 percent of sites with simazine detections, and 86 percent of sites with prometon detections were in the Valley-Fill Alluvium hydrogeologic unit. Atrazine, the most commonly used pesticide, had the most exceedances of drinking-water standards (62) and was most commonly detected (about 25 percent of all observations). Atrazine detections were significantly larger in agricultural land use than in rangeland use and were significantly larger where the principal crop was corn or sorghum. Although pesticides were not commonly detected in the deeper Ogallala Formation units, the detection of pesticides in deeper aquifers indicates that contamination pathways exist.

Dissolved-solids concentrations, which are a direct measure of salinity, had 29 percent of observations in excess of the secondary drinking-water standard of $500 \mathrm{mg} / \mathrm{L}$. Two constituents that contribute to salinity, chloride and sulfate, had 8 and 7 percent of observations exceeding their respective secondary drinking-water standards. Comparison of dissolved- 
solids concentrations prior to 1980 to concentrations after 1980 indicates dissolved-solids concentrations have increased in the vicinities of the alluvial valleys of the Platte River, the Republican River, and the Arkansas River, as well as in the Ogallala FormationSouth hydrogeologic unit. Among site characteristics, dissolved-solids concentrations generally were inversely correlated with well depth, depth to water below the water table, and soil permeability.

These water-quality results indicate that human activities are affecting the water of the High Plains aquifer. Because there is a potential for water quality to become impaired relative to the historical uses of the aquifer, water quality needs to be considered when evaluating the sustainability of the High Plains aquifer. Historical data has limitations for evaluating water quality: data are lacking for some constituents and in some areas, and data are lacking for ancillary site characteristics that are needed to understand the processes that affect water quality. Data collected as part of the High Plains Regional Ground-Water Study will help to fill in gaps in water-quality information and provide additional information for understanding the factors that govern ambient water quality.

\section{REFERENCES CITED}

Aurelius, L.A., 1989, Testing for pesticide residues in Texas well water: Texas Department of Agriculture, 188 p.

Barbash, J.E., Thelin, G.P., Kolpin, D.W., and Gilliom, R.J., 1999, Distribution of major herbicides in ground water of the United States: U.S. Geological Survey WaterResources Investigations Report 98-4245, 57 p.

Barbash, J.E., and Resek, E.A., 1996, Pesticides in ground water: Chelsea, Michigan, Ann Arbor Press, Inc., $588 \mathrm{p}$.

Center for Disease Control and Prevention, 1998, A survey of the quality of water drawn from domestic wells in nine midwest States: Atlanta, Georgia, Center for Disease Control, 25 p.

Dennehy, K.F., 2000, High Plains Regional Ground-Water Study: U.S. Geological Survey Fact Sheet FS-091-00, $6 \mathrm{p}$.

Druliner, A.D., Chen, H.H., and McGrath, T.S., 1996, Relations of nonpoint-source nitrate and atrazine concentrations in the High Plains aquifer to selected explanatory variables in six Nebraska study areas: U.S. Geological Survey Water-Resources Investigations Report 95-4202, 51 p.
Dugan, J.F., and Cox, D.A., 1994, Water-level changes in the High Plains Aquifer-Predevelopment to 1993: U.S. Geological Survey Water-Resources Investigations Report 94-4157, 60 p.

Dugan, J.T., and Zelt, R.B., 2000, Simulation and analysis of soil-water conditions in the Great Plains and adjacent areas, Central United States, 1951-80: U.S. Geological Survey Water-Supply Paper 2427, 81 p.

Engberg, R.A., 1984, Appraisal of data for ground-water quality in Nebraska: U.S. Geological Survey WaterSupply Paper 2245, 54 p.

Exner, M.E., and Spalding, R.F., 1990, Occurrence of pesticides and nitrate in Nebraska's ground water: Lincoln, University of Nebraska, Institute of Agriculture and Natural Resource Report WC-1, 34 p.

Fegeas, R.G., Claire, R.W., Guptill, S.C., Anderson, K.E., and Hallam, C.A., 1983, Land use and land cover digital data: U.S. Geological Survey Circular 895-E, $21 \mathrm{p}$.

Garcia, K.T., Maddy, D.V., Lopp, L.E., Jackson, D. Lynne, Coupe, R.H., and Schertz, T.L., 1997, User's manual for the National Water Information System of the U.S. Geological Survey, Chapter 2, Water-Quality System: U.S. Geological Survey Open-File Report 97-634, 253 p.

Gosselin, D.C., Headrick, J., Tremblay, R., Chen, X.H., and Summerside, S., 1997, Domestic well-water quality in rural Nebraska-Focus on nitrate-nitrogen, pesticides, and coliform bacteria: Ground Water Monitoring Review, Spring 1997, p. 77-87.

Gutentag, E.D., Heimes, F.J., Krothe, N.C., Luckey, R.R., and Weeks, J.B., 1984, Regional aquifer-system analysis of the High Plains aquifer in parts of Colorado, Kansas, Nebraska, New Mexico, Oklahoma, South Dakota, Texas, and Wyoming-Geohydrology: U.S. Geological Survey Professional Paper 1400-B, 63 p.

Gutentag, E.D., Lobmeyer, D.H., and Slagle, S.E., 1980, Geohydrology of southwestern Kansas: U.S. Geological Survey Open-File Report 80-128, 97 p.

Helgesen, J.O., Stullken, L.E., and Rutledge, A.T., 1994, Assessment of nonpoint-source contamination of the High Plains aquifer in south-central Kansas, 1987: U.S. Geological Survey Water-Supply Paper 2381-C, p. C1-C51.

Helsel, D.R., and Hirsch, R.M., 1992, Statistical methods in water resources: Amsterdam, Elsevier, 522 p.

Hem, J.D., 1992, Study and interpretation of the chemical characteristics of natural water (3d ed.): U.S. Geological Survey Water-Supply Paper 2254, 263 p.

Hopkins, J., 1993, Water-quality evaluation of the Ogallala aquifer, Texas: Texas Water Development Board Report 342, 41 p.

Iman, R.L., and Conover, W.J., 1983, A modern approach to statistics: New York, John Wiley, 497 p. 
Johnson, W.D., 1901, The High Plains and their utilization: U.S. Geological Survey 21st Annual Report, pt. 4-C, p. 601-741.

Kolpin, D.W., Stamer, J.K., Goolsby, D.A., and Thurman, E.M., 1998, Herbicides in ground water of the Midwest-A regional study of shallow aquifers, 1991-94: U.S. Geological Survey Fact Sheet FS-07698, 4 p.

Krothe, N.C., Oliver, J.W., and Weeks, J.B., 1982, Dissolved solids and sodium in water from the High Plains aquifer in parts of Colorado, Kansas, Nebraska, New Mexico, Oklahoma, South Dakota, Texas, and Wyoming: U.S. Geological Survey Hydrological Investigations Atlas 658, scale 1:2,500,000, 2 sheets.

Luckey, R.L., and Becker, M.F., 1999, Hydrogeology, water use, and simulation of flow in the High Plains aquifer in northwestern Oklahoma, southeastern Colorado, southwestern Kansas, northeastern New Mexico, and northwestern Texas: U.S. Geological Survey WaterResources Investigations Report 99-4104, 68 p.

McGuire, V.L., and Sharpe, J.B., 1997, Water-level changes in the High Plains Aquifer-Predevelopment to 1995: U.S. Geological Survey Water-Resources Investigations Report 97-4081, 2 plates.

McMahon, P.B., 2000, A reconnaissance study of the effect of irrigated agriculture on water quality in the Ogallala Formation, central High Plains aquifer: U.S. Geological Survey Fact Sheet FS-009-00, 6 p.

Mueller, D.K., and Helsel, D.R., 1996, Nutrients in the Nation's water-Too much of a good thing?: U.S. Geological Survey Circular 1136, 24 p.

Mullican, W.F., III, Johns, N.D., and Fryar, A.E., 1994, What a difference a playa can make-Defining recharge scenarios, rates, and contaminant transport to the Ogallala (High Plains) Aquifer, in Urban, L.V., and Wyatt, A.W., eds., Proceedings of the Playa Basin Symposium: Lubbock, Texas Tech University, Water Resources Center, Lubbock, p. 97-106.

National Atmospheric Deposition Program, 2000, Nitrogen in the Nation's rain: National Atmospheric Deposition Program Brochure 2000-01a, 13 p.

Nativ, R., 1988, Hydrogeology and hydrochemistry of the Ogallala aquifer, southern High Plains, Texas Panhandle and eastern New Mexico: Texas Bureau of Economic Geology Report of Investigations 177, 64 p.

Nolan, B.T., Ruddy, B.C., Hitt, K.J., and Helsel, D.R., 1997, Risk of nitrate in groundwaters of the United States-A national perspective: Environmental Science and Technology, v. 31, August 1997, p. 2229-2236.
Nordstrom, P.L., and Quincy, R., 1997, Ground-water data system data dictionary: Texas Water Development Board Publication UM-50, variously paged.

Perry, C.A., Robbins, F.V., and Barnes, P.L., 1988, Factors affecting leaching in agricultural areas and an assessment of agricultural chemicals in the ground water of Kansas: U.S. Geological Survey Water-Resources Investigations Report 88-4104, 55 p.

Puckett, L.J., 1995, Identifying the major sources of nutrient water pollution: Environmental Science and Technology, v. 29, no. 9, p. 408-414.

Puckett, L.J., Hitt, K.E., and Alexander, R.B., 1998, County-based estimates of nitrogen and phosphorus content of animal manure in the United States for 1982, 1987, and 1992: U.S. Geological Survey on-line dataset accessed on March 7, 2001 at URL http://water.usgs.gov/lookup/getspatial?manure.

Reeves, C.C., Jr., and Miller, W.D., 1978, Nitrate, chloride and dissolved solids, Ogallala aquifer, west Texas: Ground Water, v. 16, no. 3, p. 167-173.

SAS Institute, 1990, SAS/STAT user's guide (version 6, 4th ed.): Cary, N.C., SAS Institute, Inc., 2 v., $1,686 \mathrm{p}$.

Smith, H.T.V., 1940, Geological studies in southwestern Kansas: Kansas Geological Survey Bulletin 34, 244 p.

Smith, S.M., 1999, National Geochemical Database: Reformatted data from the National Uranium Resource Evaluation (NURE) Hydrogeochemical and Stream Sediment Reconnaissance (HSSR) Program, Version 1.10: U.S. Geological Survey Open-File Report 97492, World Wide Web release only, URL http://greenwood.cr.usgs.gov/pub/open-file-reports/ofr-970492/index.html, last accessed March 7, 2001.

Sophocleous, M., Townsend, M.A., Orountiotis, C., Evenson, R.A., Whittemore, D.O., Watts, C.E., and Marks, E.T., 1990, Movement and aquifer contamination potential of atrazine and inorganic chemicals in central Kansas croplands: Kansas Geological Survey Ground Water Series 12, 64 p.

Spalding, R.F., 1991, Assessment of statewide groundwater quality data from domestic wells in rural Nebraska: Nebraska Open-File Report, 50 p.

Spalding, R.F., and Druliner, A.D., 1981, Groundwater uranium concentrations-How high is high?, in van Duijvenbooden, W., Glasbergen, P., and van Lelyveld, H., eds.,Quality of groundwater-International Symposium, proceedings: Amsterdam, Elsevier, Studies in Environmental Science, v. 17, p. 581-586.

Steichen. J., Koelliker, J., Grosh, D., Herman, A., Yearout, R., and Robbins, V., 1988, Contamination of farmstead wells by pesticides, volatile organics, and inorganic chemicals in Kansas: Ground Water Monitoring Review, v. 8, no. 3, p. 153-160. 
Thelin, G.P., and Heimes, F.J., 1987, Mapping irrigated cropland from Landsat data for determination of water use from the High Plains aquifer in parts of Colorado, Kansas, Nebraska, New Mexico, Oklahoma, South Dakota, Texas, and Wyoming: U.S. Geological Survey Professional Paper 1400-C, p. C1-C38.

U.S. Department of Agriculture, 1991, State soil geographic (STATSGO) data base: Miscellaneous Publication Number 1492, 1 volume.

U.S. Department of Agriculture, 1999, 1997 Census of agriculture: National Agricultural Statistics Service CD-ROM Set 1A, 1B, $1 \mathrm{C}$.

U.S. Environmental Protection Agency, rev. October 18, 1999, Proposed radon in drinking water rule: U.S. Environmental Protection Agency report EPA 815-F99-006: accessed August 31, 2000, at URL http://www.epa.gov/OGWDW/radon/fact.html

U.S. Environmental Protection Agency, 1996, Drinking water regulations and health advisories: U.S. Environmental Protection Agency Fact Sheet EPA-822-B96-002, unnumbered.

U.S. Environmental Protection Agency, 1976, Quality criteria for water: Washington, D.C., U.S. Environmental Protection Agency, 256 p.

Verstraeten, I.M., Sibray, S.S., Cannia, J.C., and Tanner, D.Q., 1995, Reconnaissance of ground-water quality in the North Platte Natural Resources District, western Nebraska, June-July 1991: U.S. Geological Survey Water-Resources Investigations Report 94-4057, 114 p.
Weeks, J.B., and Gutentag, E.D., 1981, Bedrock geology, altitude of base, and 1980 saturated thickness of the High Plains aquifer in parts of Colorado, Kansas, Nebraska, New Mexico, Oklahoma, South Dakota, Texas, and Wyoming: U.S. Geological Survey Hydrologic Investigations Atlas HA-648, scale 1:2,500,000, 2 sheets.

Weeks, J.B., Gutentag, E.D., Heimes, F.J., and Luckey, R.R., 1988, Summary of the High Plains regional aquifer-system analysis in parts of Colorado, Kansas, Nebraska, New Mexico, Oklahoma, South Dakota, Texas, and Wyoming: U. S. Geological Survey Professional Paper 1400-A, 30 p.

Whitmore, R.W., Kelley, J.E., and Reading, P.L., 1992, National home and garden pesticide use surveyFinal report: Research Triangle Park, North Carolina, Research Triangle Institute, Report to the U.S. Environmental Protection Agency, Office of Pesticides and Toxic Substances, Biological and Economic Analysis Branch under contract 68-WO-0032, v. 1, 138 p.

Wilcoxon, Frank, 1945, Individual comparisons by ranking methods, Biometrics, v. 1, p. 80-83.

Zielinski, R.A., and Asher-Bolinder, Sigrid, 1996, Uraniferous waters of southeastern Colorado; a function of geology, climate and land use, in Morganwalp, D.W. and Aronson, D.A., eds., U.S. Geological Survey Toxic Substances Hydrology Program: Proceedings of the technical meeting, Colorado Springs, Colorado, September 20-24, 1993, U.S. Geological Survey Water-Resources Investigations Report 94-4015, p. 805-812. 
APPENDIX 



\section{Appendix A. Description of data on the CD- ROM and instructions on the use of the data base}

The retrospective data base is on the CD-ROM in two formats: Microsoft Access mdb file and ASCII files. The Access mdb file Data.mdb is a single selfcontained file that includes the data base. Microsoft Access software is required to enable use of this file. ASCII versions of files can be used as they are or loaded into any data-base software that reads standard ASCII format; there is a separate ASCII file for each table in the data base. If ASCII files are loaded into a relational data base, the tables should be linked as depicted in the relationship diagram in Appendix B-4.

Files on CD-ROM are read only. Therefore, to make changes to files (for instance, when making a query in a MS Access data base), the files should first be copied to a hard drive, and the read-only access restrictions should be removed.

Additional information on the use of the data base in either Microsoft Access or ASCII formats can be found in the README_ASCII.txt files and

README_ACCESS.txt files on the CD-ROM.

\section{Appendix B. Diagrams showing content and structure of the data base}

The following four tables give information about the content of the High Plains retrospective water-quality data base. Table B-1 shows a listing of the tables in the data base as presented in the Access data-base container. Users loading data from ASCII format need to create these same tables by loading separate ASCII files. Table B-2 shows the fields included in the SITE data-base table, and table B-3 shows the fields in the QW_RESULT data-base table. Table B-4 shows a relationship diagram for the High Plains retrospective data base. The data base is a relational data base, and for optimal use, the individual tables need to be linked in the manner depicted in table B-4 to allow full querying capabilities of the data. 


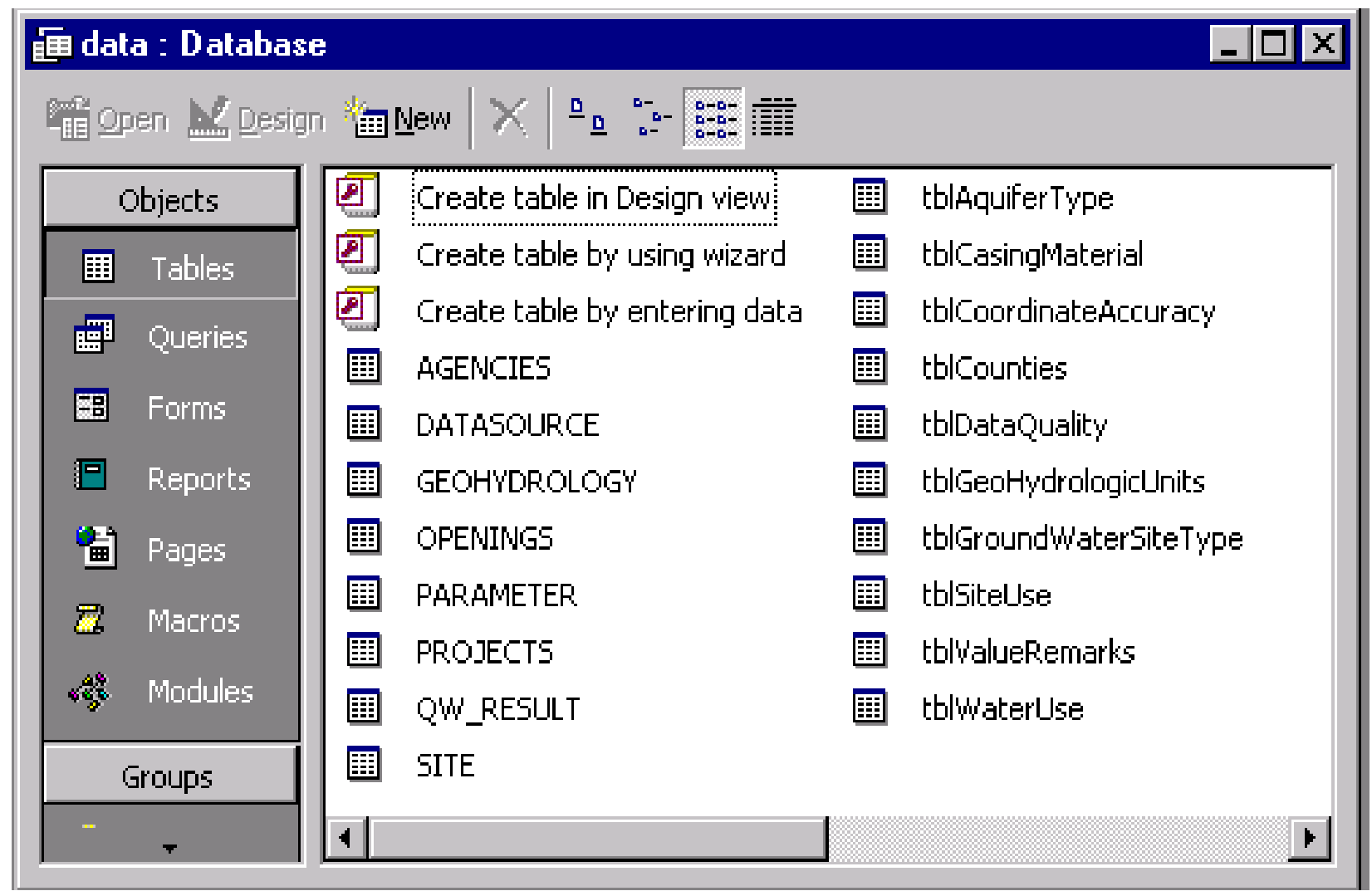

Appendix B-1. Tables included in the High Plains retrospective water-quality data base. 


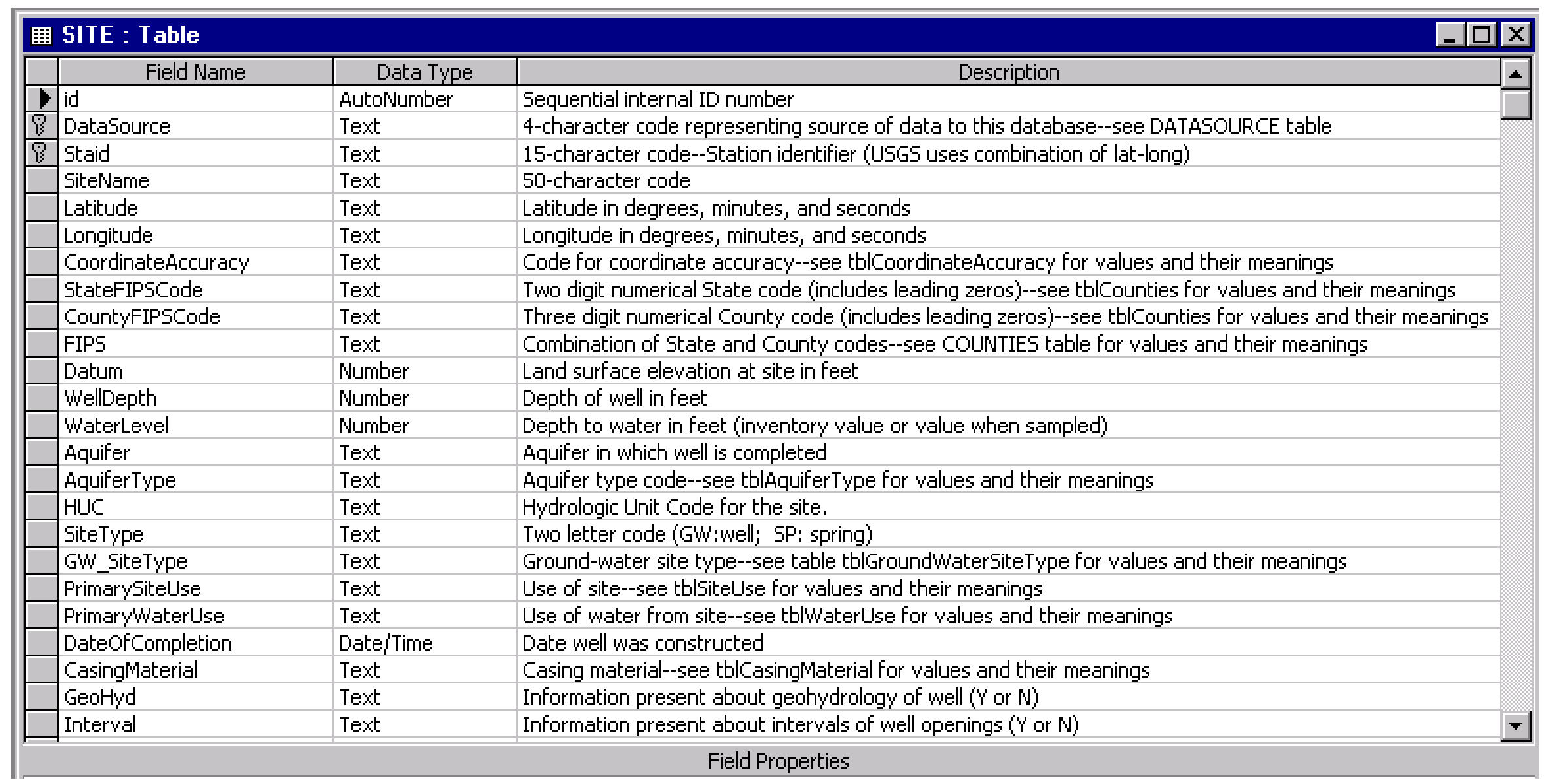

Appendix B-2. Data fields included in SITE table of High Plains retrospective water-quality data base. 


\section{圈 QW_RESULT : Table}

- $\square x$

\begin{tabular}{|l|l|l|l|l|}
\hline \multicolumn{1}{|c|}{ Field Name } & \multicolumn{1}{|c|}{ Data Type } & \\
\hline & id & Number & Sequential id \\
\hline P & DataSource & Text & 4-character code representing source of data to this database \\
\hline P & Staid & Text & 15-character code--Station identifier (USGS uses combination of lat-long) \\
\hline B & Dates & Date/Time & Date sample was taken; missing dates are represented by 1/1/1111 \\
\hline B & Times & Number & Time sample was taken; missing times are represented by -9999 \\
\hline B & Ppcode & Text & The letter "P" followed by the STORET parameter code \\
\hline & Value & Number & Numerical value for parameter \\
\hline & ValueRemark & Text & Remark for value (see tblvalueRemarks for meaning of remark codes) \\
\hline DataQuality & Text & The quality of the value (see the tblDataQuality for matrix for assigning DataQuality) \\
\hline DataProject & Text & Project code for value (see PROJECTS table for project information) \\
\hline DataAgency & Text & Agency code for agency which collected data (see AGENCIES table for agency information) \\
\hline & & & \\
\hline
\end{tabular}

Appendix B-3. Data fields included in QW_RESULT table of High Plains retrospective water-quality data base. 


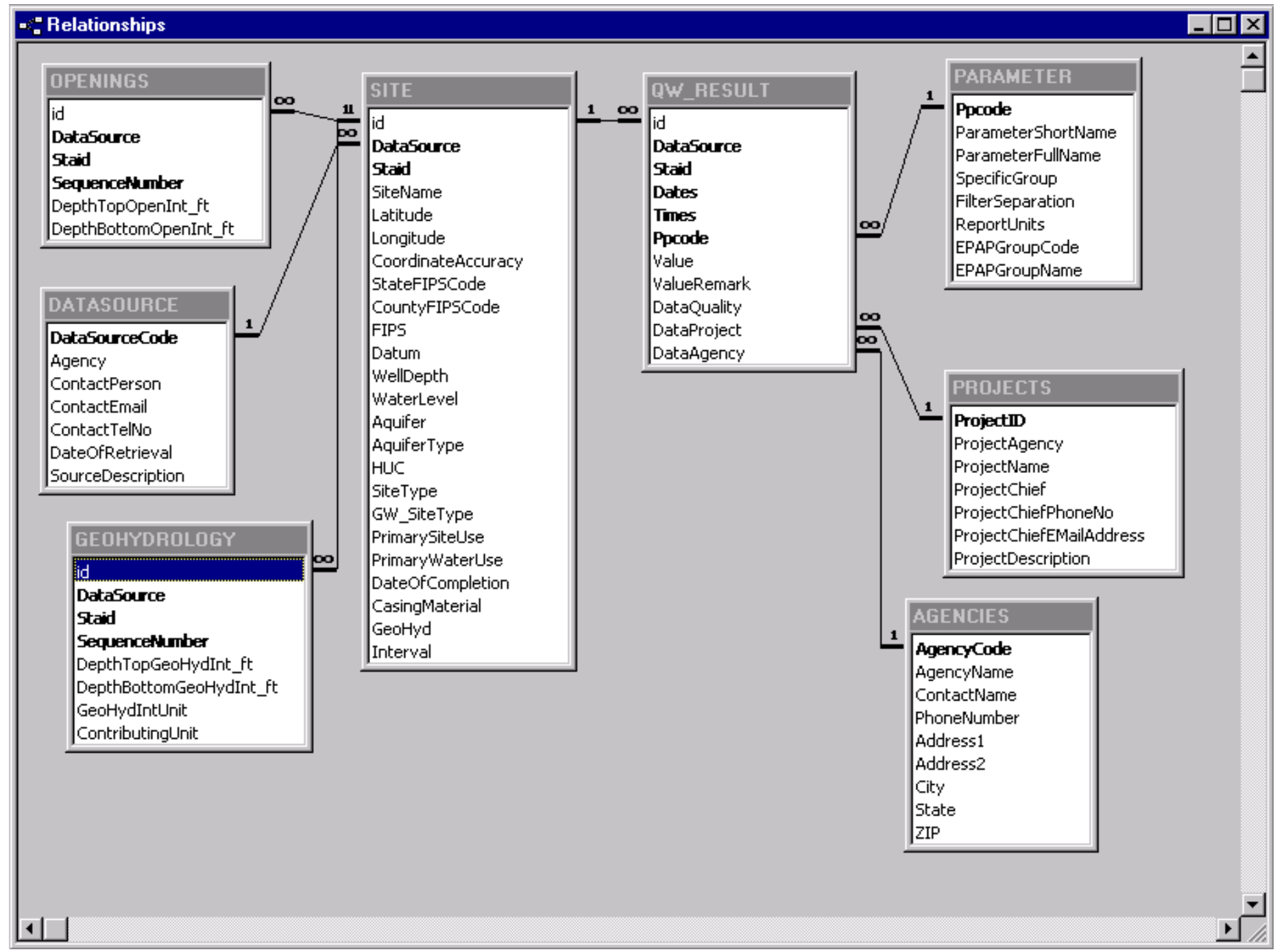

Appendix B-4. Relationship diagram for High Plains retrospective water-quality data base. 